\title{
NATURAL HISTORY
}

OF THE

\section{KING RAIL}




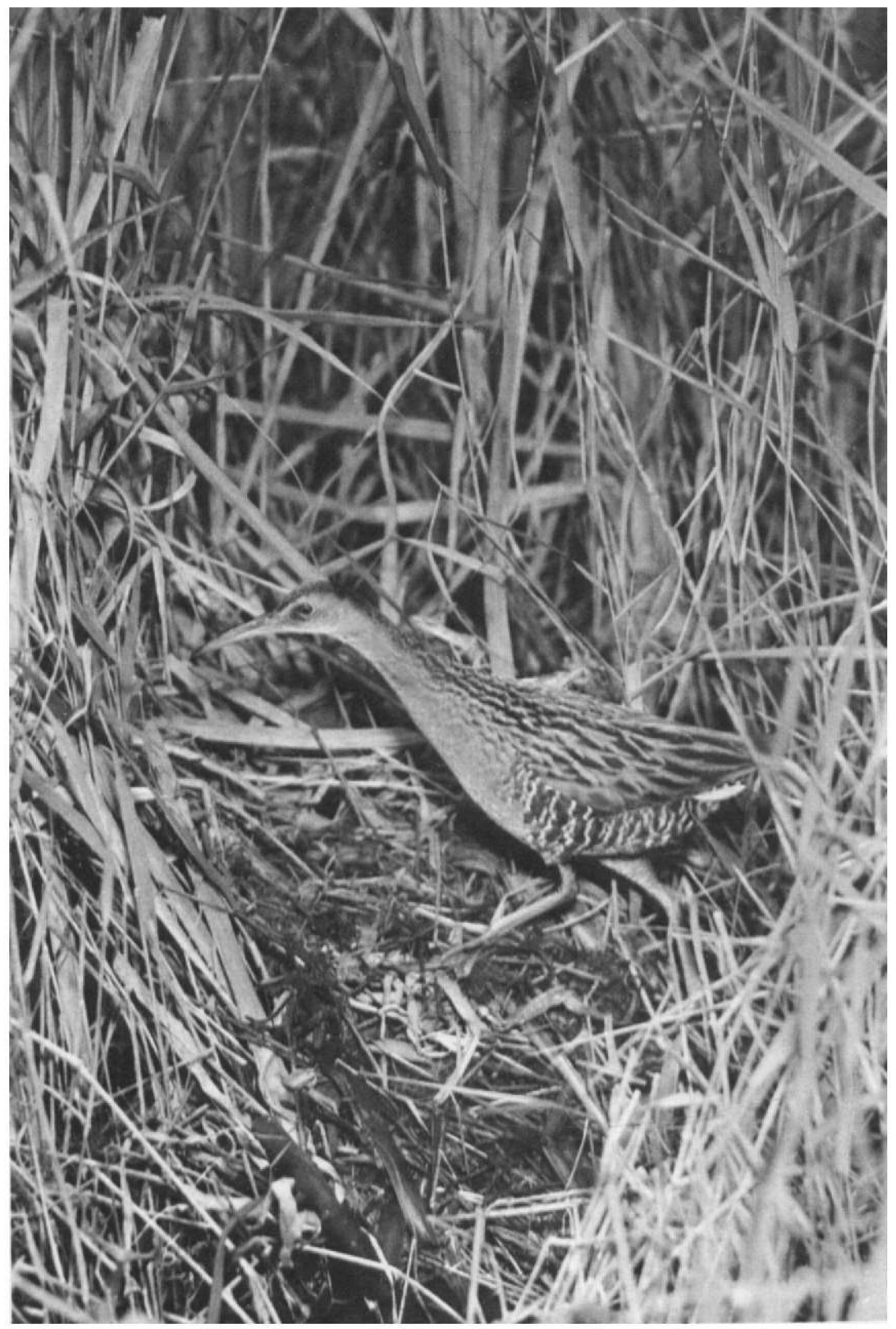

King Rail near Jacksonville, Fla. (Photograph by Samuel A. Grimes) 


\section{NATURAL HISTORY \\ OF THE \\ KING RAIL}

By Brooke Meanley, Wildlife Biologist

Paturent Wildlife Research Center

Division of Wildlife Research

BUREAU OF SPORT FISHERIES AND WILDLIFE

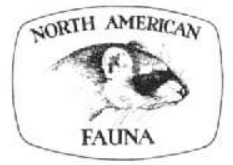

NUMBER 67 


\section{UNITED STATES \\ DEPARTMENT OF THE INTERIOR \\ Walter J. Hickel, Secretary}

Leslie L. Glasgow, Assistant Secretary for

Fish and Wildlife, Parks, and Marine Resources

FISH AND WILDLIFE SERVICE

Charles H. Meacham, Commissioner

BUREAU OF SPORT FISHERIES AND WILDLIFE

John S. Gottschalk, Director

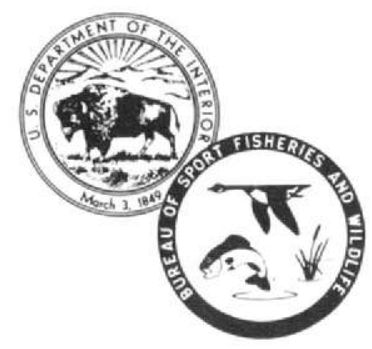

North American Fauna, Number 67

Published by

Bureau of Sport Fisheries and Wildlife

May 1969

D.S. GOVERNMENT PRINTING OPFTCH

WASHINGTON : 1969

For sale by the Superintendent of Documents, U.S. Government Printing Office

Washington, D.C. 20402 - Price 60 cents 


\section{Contents}

INTRODrction

Higtoky and Sygtematic Position

History .................. 4

Systematic position ..................... 6

Relationship to the Clapper Rail

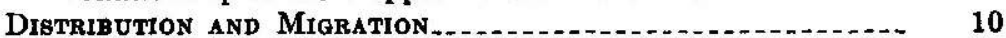

Distribution...

Migration

Local movements..................................... 14

Ecological RgLations. .

Louisians gulf cosst marshes........................... 16

The delta margh

The subdelta marsh

The prairie marshes................................. 18

Southern ricefields ...

Florida

South Carolina Low Country

Savannah National Wildlife Refuge................. $\quad 29$

Upper Savannah River Valley_..................... 32

Chesapeake Bay Country.............. 32

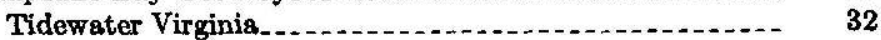

Virginia Eastern Shore

Maryland Eastern Shore

Inner Coastal Plain of Maryland............... 38

Delsware Bay, Del_.............. 39

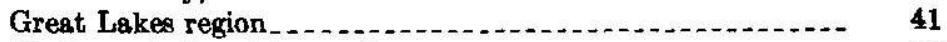

North-central prairie marehes

Northern Great Plains.............. 42

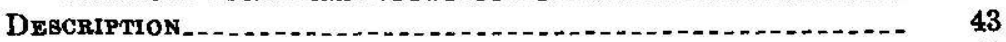

Size

Adult plumage.............. 43

Legs and feet............. 45

Bill ....................... 45

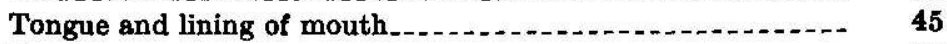

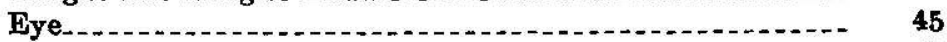

Notes on sexing and aging .............. 45

Molting-............. 46

Breming Blologx ......... 48

Homing- . .

Territories.

Defense of territories................ 49

Courtship behavior...................... 50

Mating call and pair formation...... 50

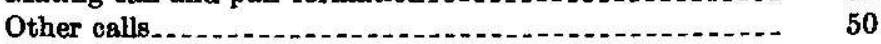

Display

Courtship feeding -........ 53 
Prenesting activity

Calling .

Symbolic nest building -

Copulation

Nesting period...... 54

Nest site and materials

Egg laying and clutch size....... 61

Clutch size......... 61

Description of eggs_... 61

Weight of eggs

Incubation

Hatching . .

Nesting success and survival

Breeding status of first-year birds

Defelopment and Behavior of Captive Rails .

Development of Young

First-day chick

One to thirty days

Thirty to sixty days

First winter plumage...... 72

Miscellaneous notes on behavior of young

Sleeping - 72

Competition . 73

Bathing . . 73

Winter behavior of captive rails .

Foods_._.

Arkansas ricefields .

Texas ricefields

Louisiana ricefields

Upper St. Johns River, Fla___. 79

Currituck Sound, N.C. 79

Patuxent River, Md. $\quad 80$

Beaver Dam, Wis.

Chicago, Ill... 80

Feeding Behavior. 81

Pellet casting

Feeding young

Regional observations

Arkansas ricefields

Delaware Bay marshes ........... 83

Savannah National Wildlife Refuge... 84

Some unusual observations

MoRTALITY FACTOR8_._. 86

Manmade objects

Predation.... 86

Hurricanes... 88

The King Rail as a Game Bird... 90

Methods of hunting. 90

Patuxent River, Md. 91

Eagle Lake area, Tex

Other areas. 93

SUMMARX

Literature Cited . 98 
ApPENDIX 1-Methods or Capturing for Bandina.

Types of capturing devices.

Long-handled dip or clap net................... 103

All-purpose or cloverleaf trap $\ldots . \ldots 3$

Tending traps......... 105

Age for banding King Rail chicks.............. 106

Need for banding data $\ldots$

APPENDIX 2,-LocaL NAMES_._.

\section{ILLUSTRATIONS}

Frontispiece, King Rail near Jacksonville, Fla....... ii Froure

1. A King Rail walking

2. Mated King Rail and Clapper Rail collected in Delaware_..- 8

3. Approximate breeding range and principal distribution of the King Rail in North America.........

4. Louisiana coastal marshes_.

5. Prairie marsh, Grand Chenier, La.................. 18

6. Southern bulrush, fall panicum, and alligatorweed in the

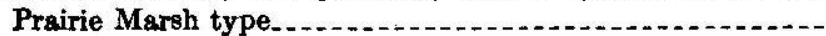

7. King Rail wading through ricefield

8. Arkangas Grand Prairie near Stuttgart. . . . . . . . . . . . 23

9. Nest of King Rail in wet rice stubble

10. Habitat of King Rail, Indian River County, Fla.......... 26

11. King Rail habitat on Seminole Indian Reservation, Glades

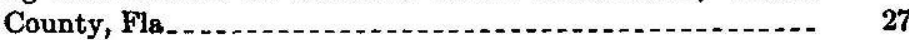

12. Floodgate and ricefield canal near Savannah, Ga ......... 28

13. South Carolina Low Country: ricefield nesting habitat along Savannah River, Jasper County ......................

14. Alligatorweed in canal at Savannah Nationsl Wildlife Refuge

15. Big cordgrass habitat, Nanticoke River marsh, Md..........-

16. Winter abode of King Rail, Rappahannock River near Tappa-

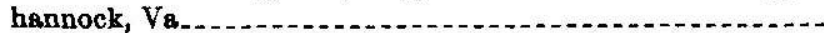

17. Switchgrass habitat of King Rail, Elliott Island, Md.......

18. Nest and eggs of King Rail in Nanticoke River marsh, Vienna, Md.

19. Nest and 9 eggs of King Rail in brackish marsh, Long Marsh Island, Eastern Bay (of Chesapeake Bay), Md..........

20. Taylor's Gut at low tide, Kent County, Del..............

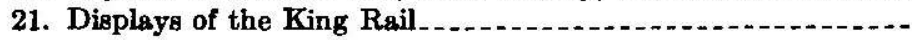

22. Canopy on King Rail nest in rosdside ditch, Arksnsas Grand Prairie

23. King Rail nest in roadaide ditch near Stuttgart, Ark

24. King Rail incubating in nest of cattails in roadside ditch,

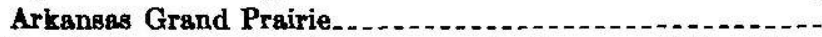

25. King Rail incubating in open nest along roadside ditch, Mamou, La . . . .

26. Distraction display of King Rail near nest...........

27. Downy young King Rail, 31 days old, with juvenal plumage beginning to develop.

28. Ventral view of 31-day-old King Rail showing development of white juvenal plumage in sternal and abdominal regions and crural tract. 
29. Fifty-day-old King Rail with juvenal plumage nearly com-

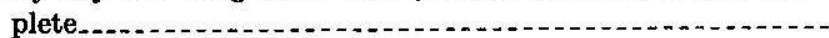

30. Captive King and Clapper Rails at Patuxent Wildlife Research Center, Laurel, Md.

31. Foods of the King Rail in a brackish bay marsh, Kent County, Del.

32. Regurgitated King Rail pellets from Dorchester County, Md. -

33. Method of hunting railbirds in Patuxent River wildrice marshes, Maryland.

34. Railbird boats tied up after the hunting season . .

35. Method of hunting railbirds in southern ricefields......... 94

36. All-purpose or cloverleaf trap and drift fence in shrub swamp at Patuxent Wildlife Research Center................ 104

37. All-purpose or cloverleaf trap.

Photographs are by the author unless otherwise credited. 


\section{Introduction}

The King Rail (Rallus elegans Audubon), largest of North American rails, is indeed an elegant bird, as its Latin name implies. Its striking appearance (fig. 1), secretive nature, and association with a variety of wetland habitats make it a favorite of bird students and rail hunters. The King Rail is found in most of the eastern half of North America, from the Atlantic coast to the Great Plains and from the Gulf of Mexico to southern Canada. It is most abundant in the fresh and brackish tidal marshes of the Atlantic and Gulf Coastal Plain, the domestic ricefields of Arkansas, Louisiana, and Texas, and the marshes of southern Florida. It is fairly common in parts of the Midwest Prairie and Great Lakes region.

I began my studies of this interesting bird in 1950 in the Arkansas ricefields, and have continued them until 1967, both in the field and in the laboratory.

Many of the field observations, particularly those of courtship behavior, were made from an automobile which served as an admirable mobile blind. Such a blind was used to follow courting rails along roadside ditches in Arkansas and Louisiana, making it possible to study the detailed nuptial courtship behavior of 20 different pairs and the prenuptial behavior of four. Under these conditions it was possible also to distinguish the sexes by their behavior rather than by their size differences, which are sometimes difficult to ascertain in the field.

The highly vocal nature of the King Rail and its characteristic calls, varying with different conditions, enhance the value of field observations and made the call-count census a practical technique.

Studies of growth and development of the young were made with captive birds, which are quite tractable if obtained early in life from nests or hatched from eggs in incubators.

Studies of breeding biology were made mostly on the Arkansas Grand Prairie in the vicinity of Stuttgart from 1950 through 1955. Subsequent studies on life history and ecology were made at Mamou, Evangeline Parish, La.; Broadway Meadows near Woodland Beach, Kent County, Del.; the Pee Dee River at Georgetown, S.C.; the Savannah National Wildlife Refuge, Jasper County, S.C.; and the Patuxent Wildlife Research Center, Laurel, Md. 
I have supplemented my own observations with a review of the published studies of others and have attempted to bring all information on the King Rail together into a monographic treatment.

My discussions in this paper include the history of the discovery of the King Rail as a distinct species by Audubon in 1834 and its systematic position in relation to the Clapper Rail, as taken mostly from the literature. The discussions of other topics are largely from my own observations, but supplemented with literature reports. The principal topics include distribution and migration; ecological relations; physical characteristics; breeding biology; development and behavior of captive rails; foods and feeding; mortality factors; and the King Rail's position as a game bird. Appendixes include methods of capturing and banding and a list of local names. Aquatic plant names used in the text are from Hotchkiss (1950) unless otherwise indicated.

I am indebted to many persons for assistance with this project. Anna Gilkeson Meanley, my wife, assisted with the fieldwork over a 7-year period in Arkansas and Louisiana. E. R. Kalmbach, former Director of the Denver Wildlife Research Center, made the sketches of courtship displays and offered encouragement and many suggestions during the early phases of the study in Arkansas. Other colleagues from the Bureau of Sport Fisheries and Wildlife who were most helpful in various phases of the work include Nancy C. Coon, John W. Aldrich, Van T. Harris, Lucille F. Stickel, Paul A. Stewart, Robert E. Stewart, Charles C. Sperry, Neil Hotchkiss, Francis M. Uhler, Frederick C. Schmid, Glen Smart, Johnson A. Neff, Robert G. Heath, Luther C. Goldman, and David K. Wetherbee. Anthony J. Florio of the Delaware Game and Fish Commission was helpful in Delaware studies. I am grateful to Samuel A. Grimes of Jacksonville, Fla., for his photograph of a King Rail used as the frontispiece. 

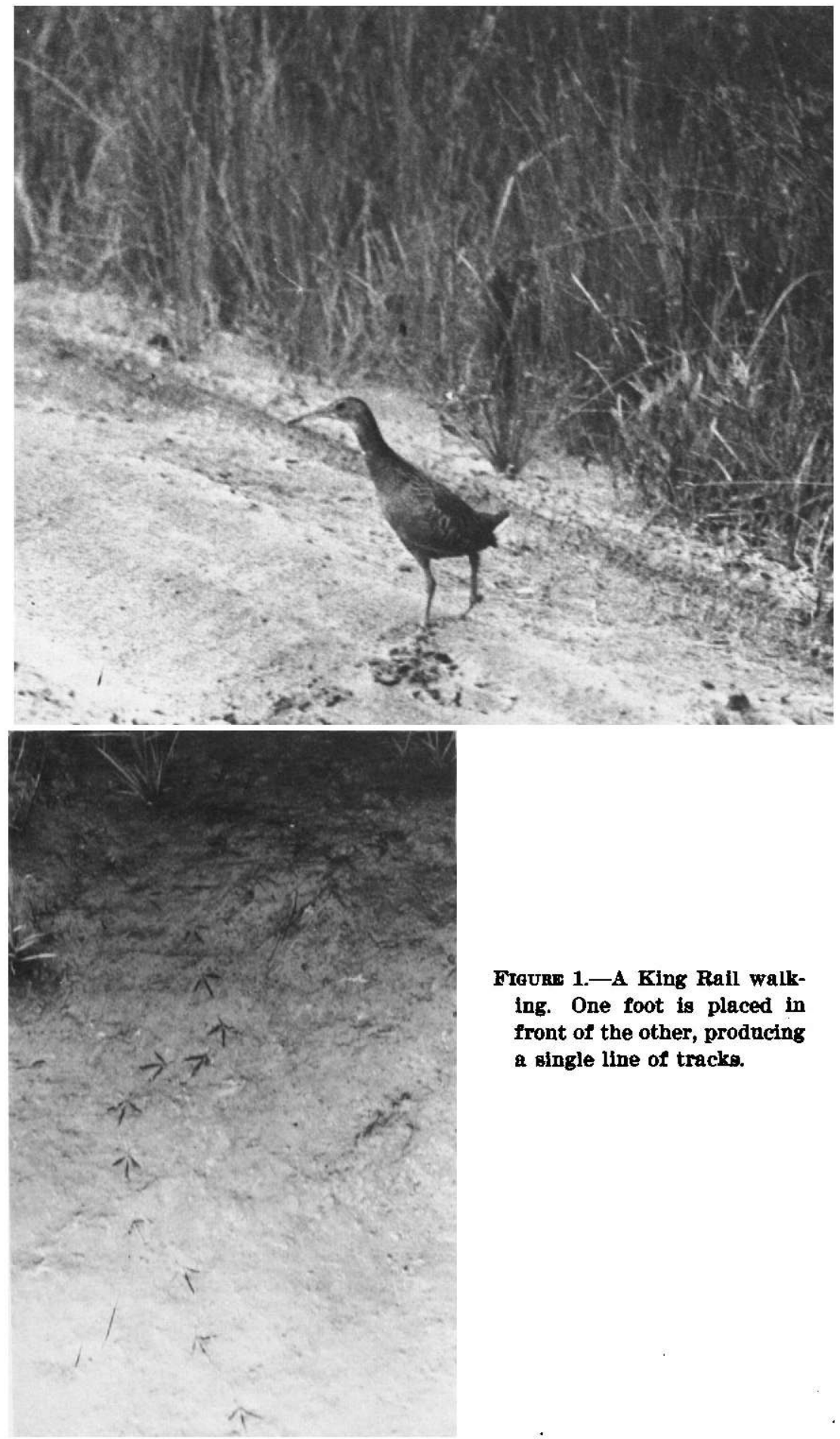

Freure 1.-A King Rail walking. One foot is placed in front of the other, producing a single line of trackg. 


\section{History and Systematic Position}

\section{HISTORY}

John James Audubon published the first description of the King Rail as a distinct species. The Great Red-breasted Rail or Fresh-water Marsh Hen, as he called it, was introduced with the publication of his painting in Birds of America (Audubon, 1834, plate 203). A year later a description of this new rail appeared in his Ornithological Biography (Audubon, 1835, p. 27-32).

Alexander Wilson, Audubon's predecessor, encountered this same species but thought it was the adult form of the Clapper Rail (Rallus longirostris), "following the current opinion of gunners that it was a very old example of that species" (Stone 1908, p. 110). Elaborating on this point, Audubon (1835, p. 27) stated:

No doubt exists in my mind that Wilson considered this beautiful bird merely the adult Rallus crepitans [Rallus longirostris crepitans], the manners of which he described, as studied at Great Egg Harbour, New Jersey, while he gave in his works the flgure and colouring of the present species. My friend, Thomas Nuttall, has done the same, without, I apprehend, having seen the two together. Always unwilling to find fault in so ardent a student of nature as Wilson, I felt almost mortified when, after having in the company of my worthy and learned friend, the Reverend John Bachman, carefully examined the habits of both species, which in form and general appearance, are closely allied, I discovered the error which he had in this instance committcd. Independently of the great difference as to size between the two species, there are circumstances connected with their habits which mark them as distinct. The Rallus elegans is altogether a fresh-water bird, while $R$. crepitans never removes from the salt-water marshes ...

J. d'Arcy Northwood (1956, p. 224), commenting on Audubon's discovery, said:

The king rail was one of Audubon's scoops. Here was a large rail, not particularly rare, that lived unknown and undescribed under the noses of the experts in Philadelphia. Audubon realized that it was distinct from the clapper rail of the salt marshes, with which it had been confused, and named it the Great Redbreasted Rail or Fresh-Water Marsh Hen.

The type locality given in the American Ornithologists' Union Check-list of North American Birds (1957, p. 152) is Kentucky, South Carolina, Louisiana, and north to Camden, N.J., and Philadelphia $=$ Charleston, S.C.

Although Audubon collected and observed the King Rail in several localities prior to his field studies in company with Bachman in the 
Charleston, S.C., region, it is apparent from his original description (Audubon, 1835) that he finally decided that it was indeed a new species on the basis of their work in that region. It would seem that the species distinctness may even have been brought to his attention by Bachman, who in a letter to Audubon sent from Charleston, S.C., and dated December 27,1832 , posed this question:

May not the Northern Marsh Hen, be the Bird which we here call the Fresh Water M. Fen \& our Ash coloured one that keeps to the Marsh be peculiar to the South? I should like to have this matter ascertained.

In a letter from Charleston dated March 27, 1833, Bachman, again referring to the Marsh Hen, said (Deane, 1929, p. 180, 184), "My opinion first expressed [in the letter of December 27, 1832] is every day strengthened."

Audubon (1835, p. 27-28) reported that he caught a female at Henderson, $\mathrm{Ky}$., on May 29, 1810, and also collected a female near Camden, N.J., in July 1832.

Stanley C. Arthur (1937, p. 503), a biographer of Audubon, believed that Audubon's painting of the Fresh-water Marsh Hen was made at New Orleans in 1821 when he spent the winter, spring, and fall there. Audubon obtained birds from the city market and from two hunters engaged to collect for him, and painted over 100 birds from this area (including work in the St. Francisville area in West Feliciana Parish). An entry in Audubon's journal, dated December 20, 1821 (Corning 1929 , p. 224), says that he "Rec a nondescript rail." And an entry made the next day says, "Drew a streaked Rail." This may have been a King Rail, but if it was, apparently it was not recognized as a new species at that time.

An interesting letter from Rodolphe M. deSchauensee, Curator of Birds at the Academy of Natural Sciences in Philadelphia, dated February 7, 1962, sheds some light on the possibility of an existing type specimen or cotype:

I have gone into the question of the type specimen of the King Rail mentioned in your letter of February 1 with what $I$ think are interesting results.

Some years ago Fletcher and Phillips B. Street gave to the Academy a collection of birds which had belonged to Edward Harris who was a friend of Audubon. On looking through our collection I found in this lot an immature specimen of the King Rail. In vol. 3 (p. 28) of Audubon's Ornithological Biographies he says "I killed one female in New Jersey, a few miles from Camden, in July, 1832 in company with my friends Edward Harris and Mr. Ogden . . ."

In the Elephant Folio (vol. 3) pl. 203 engraved in 1834 two birds are ahown, an adult and an immature. The bird in Harris's collection agrees very well both in color and measurements with the bird depicted as the immature specimen. $\mathbf{A s}$ the bird was collected in 1832 the plate engraved in 1834 and Audubon's original description published in $\mathbf{1 8 3 5}$, there is every reason to suppose that this is the bird shown on the plate.

In view of all the above $I$ feel that it is justifiable to regard this specimen as a cotype. Audubon described an adult male, a female and an immature. If 
these three birds all existed today they would of course all be cotypes. In the plate the female is not figured, only the adult male and young.

If this specimen were to be accepted as a cotype, the type locality would have to include Camden, N.J. However, in his original description of $R$. elegans, Audubon (1835) said that most of his observations of this species were in South Carolina.

\section{SYSTEMATIC POSITION}

The King Rail belongs to the order Gruiformes, which in North America includes the cranes, limpkins, rails, gallinules, and coots. Birds of this group mostly inhabit wetland environments, particularly marshes.

The suborder Grues includes the families Gruidae (cranes) and Aramidae (limpkins). Rails, gallinules, and coots belong to the suborder Ralli, which contains a single family, Rallidae. In North America this family comprises seven genera and nine species.

The three North American species of the genus Rallus, $R$. elegans (the King Rail), R. longirostris (the Clapper Rail), and R. limicola (the Virginia Rail), have laterally compressed bodies which facilitate passage through dense marsh vegetation; rather long, slender, and slightly curved bills which are as long as or longer than the tarsi, and longer than the heads; large, strong legs; long, slender, unwebbed toes; short, rounded wings (with vestigial claws); short, tip-up, pointed tails less than half as long as the wings; flanks conspicuously barred with white; olive or grayish dorsal regions which are striped with black or dusky markings; and buffy or rufescent breasts. $R$. elegans is larger than $R$. limicola, which it resembles in color, and is more rufescent than races of $R$. longirostris but is about the same size as that species.

Two races of the King Rail are generally recognized: Rallus elegans elegans of North America, and Rallus elegans ramsdeni, the Cuban form. Apparently a third form, Rallus elegans tenuirostris, occurs in the fresh-water marshes of the Valley of Mexico. There is a difference of opinion concerning the systematic position of tenuirostris, some authors assigning it to Rallus elegans and others to Rallus longirostris. The recent work of Warner and Dickerman (1959) seems to indicate that the plumage and inland distribution of this form are more like that of Rallus elegans.

\section{RELATIONSHIP TO THE GLAPPER RAIL}

Some ornithologists believe that King and Clapper Rails are merely races of the same species. Structurally and behaviorally they are similar. The plumages of several Clapper races closely resemble that of the King Rail. Their breeding ranges overlap in numerous coastal brackish marshes, in at least one of which there is absolute evidence of interbreeding resulting in the production of viable eggs. 
Oberholser (1937, p. 314-315), in discussing the relationship of these two species, stated that-

It remains yet to determine the status of the king rall, Rallus elegans, of the Frastern United States, and its single subspecies, Rallus elegans ramsdeni, of Cuba. This is an unusually difficult matter to decide, and one concerning which there may well be difference of opinion. The chief external characters separating the ling rails from the clapper rails consist in the much more reddish bend of the wing, and in the rich rufescent-olive tinge of the upper parts of the former birds, this involving both the centers and margins of the feathers. There is little or no trenchant difference in behavior, volce, nest building, or other habits between these two species. Nelther one of the external characters of plumage above mentioned, nor any difference in size or proportions, is entirely trenchant when all the races of Rallus longirostris are included.

The occurrence of King and Clapper Rails in the same breeding grounds has been observed by several ornithologists. Robert E. Stewart (personal communication) observed a King and a Clapper Rail together with brood at Chincoteague Island on the coast of Virginia in June 1951. He has also on numerous occasions observed King and Clapper Rails together in the tidal marsh along Ape Hole Creek, a tributary of Pocomoke Sound, Somerset County, Md. H. M. Stevenson reported seeing a Clapper Rail walking directly in front of a King Rail at Alabama Point, Ala., June 6, 1965 (Stewart, J. R., 1965, p. 553). In April 1956, I collected a King Rail and a Clapper Rail from the same pond at Grand Chenier, Cameron Parish, La. In this area, the narrow chenier (stranded rim of the sea or old shoreline) serves somewhat as a barrier between the fresh and salt marsh, and these two species merely have to walk a hundred yards or so to be together. It is difficult to separate the two species in the field in the gulf coast marshes, although the breast of the resident Clapper race, $R$. $l$. saturatus, is duller brown in contrast to the more rufescent breast color of the King Rail.

On the South Atlantic coast, Ivan R. Tomkins (1958, p. 11) encountered a similar situation near Savannah, Ga. He wrote:

This brackish area, a place of transition from fresh to salt, has some peculiar gituations in respect to bird habitats. In the middle of Elba Island I have seen both King and Clapper Ralls on territory so close together that both birds were in view at the same time.

In the New York City region, John Bull (1964, p. 169) reported 11. specimens and 19 sight records of King Rails in coastal salt marshes and a January record of two King Rails feeding with a Clapper Rail on a mud flat at Lawrence.

On May 18, 1960, John S. Webb and I observed a King Rail and a Clapper Rail together in a brackish tidal marsh along the Delaware Bay near Fleming's Landing, Kent County, Del. The mated pair (fig. 2) were observed on their nesting territory on numerous occasions thereafter and were collected on June 11. The nest was also located on that date, and the five eggs were removed and placed in an incubator. Despite the fact that optimal incubation conditions were main- 


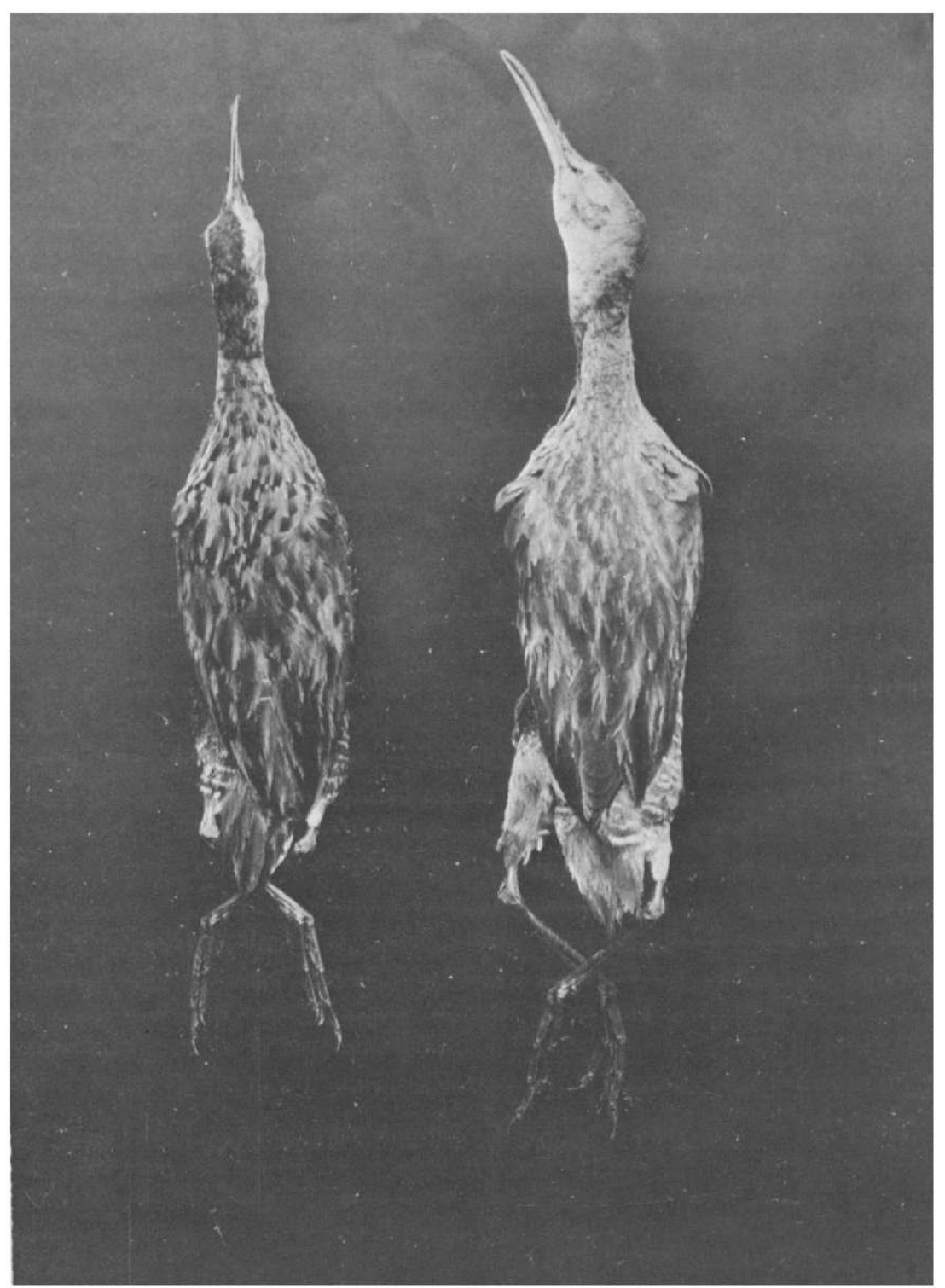

Froure 2.-Mated King Rail (subadult female) left, and Clapper Rail (adult male) right, collected at Taylor's Gut, Kent County, Del., June 11, 1960. Eggs of pair were fertile. (Photograph by Frederick C. Schmid.) 
tained (64 percent relative humidity and $37.8^{\circ} \mathrm{C}$. forced draft) (Wetherbee, 1959) the embryos died between the 17th and 19th days of incubation. The embryos appeared to be normal, and the deaths were believed to have been accidental rather than indicative of genetic incompatibility.

Subsequent observations revealed that King and Clapper Rails frequently were found together in the extensive brackish bay marshes in the Taylor's Gut area known as Broadway Meadows and located between Fleming's Landing and Woodland Beach, Del. (Meanley and Wetherbee, 1962, pp. 453-457; Meanley, 1965, pp. 3-7).

During the breading seasons of 1960-64, a eries of opecimens was collected in the Broadway Meadows marsh for plumage analysis. Specimens were obtained at three stations: $(a)$ the upper reaches of the brackish marsh at Fleming's Landing, where King Rails only were observed; $(b)$ the outer brackish marsh at Woodland Beach on Delaware Bay, where Clapper Rails only were observed; and $(c)$ the intermediate area between these two stations at Taylor's Gut, where both Kings and Clappers occurred. Specimens from the intermediate area showed a wide variation from typical King plumage to typical Clapper plumage (table 1).

In addition to the localities mentioned, there are undoubtedly many other such areas in the brackish marshes of the Atlantic and Gulf Coastal Plain where mixed King Rail and Clapper Rail populations occur. In fact, almost any Coastal Plain river that has extensive brackish marshes and a sizable fiddler crab population is a potential KingClapper mixing ground.

TABLE 1.-Specimens randomly collected from Taylor's Gut, Del., an area of mixed King and Clapper Rail populations

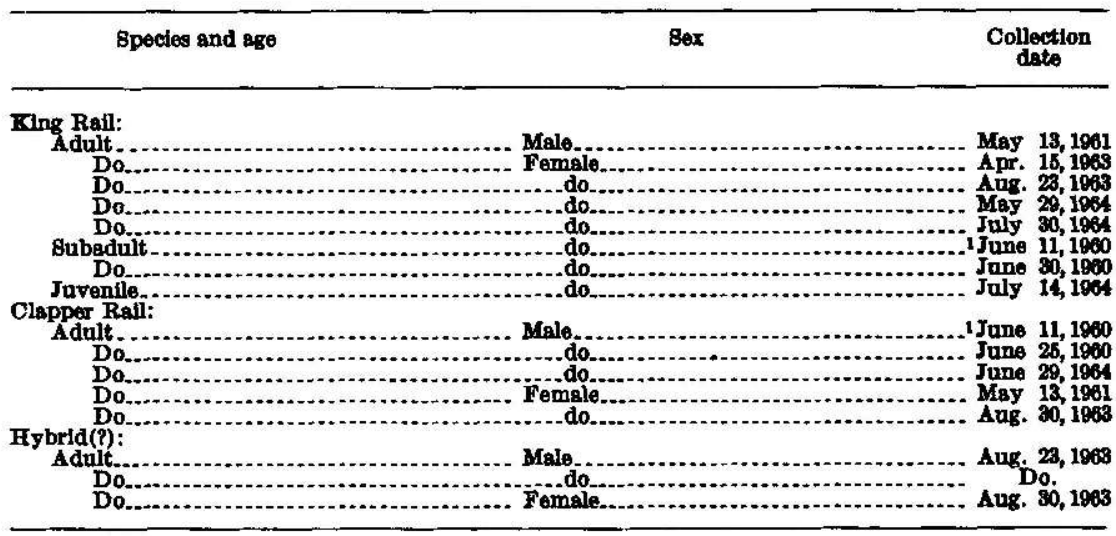

1 Paired and active nest found. 


\section{Distribution and Migration}

\section{DISTRIBUTION}

Unlike the Clapper Rail, which in the eastern United States is mainly restricted to a rather narrow band of salt marshes along the Atlantic and gulf coasts, the King Rail is found throughout the eastern half of North America. In general, its breeding range extends from the Gulf of Mexico to southern Canada and from the Atlantic coast to about the 100th meridian in the Great Plains (fig. 3).

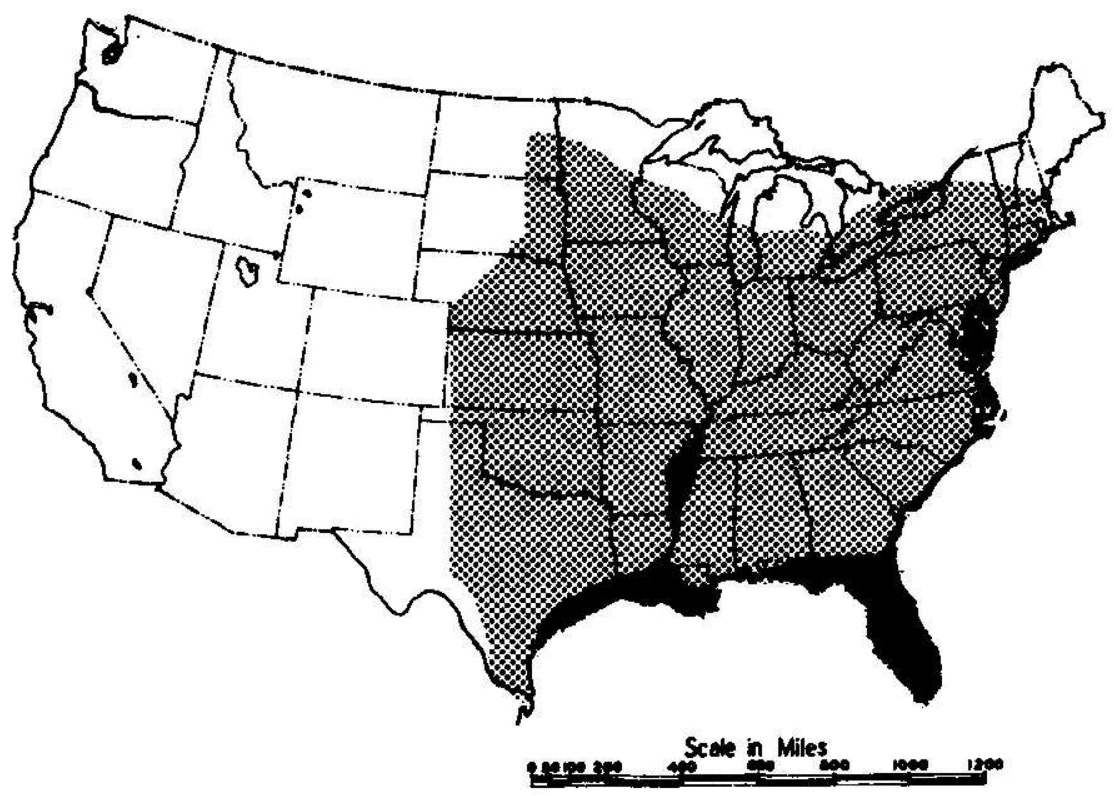

Frouke 3.-Approximate breeding range and principal distribution of the King Rail in North America (black shaded area along Gulf and Atlantic Coasts and in Iower Mississippi Valley and peninsular Florida indicates main wintering range).

The boundaries of the breeding range as given in the American Ornithologists' Union Check-list (1957, p. 152) and supplemented by additional records, mostly from the distribution files of the Section of Migratory Non-Game Bird Studies, Migratory Bird Populations Station, Laurel, Md., and from Audubon Field Notes, are as follows: The northern boundary extends from southeastern North Dakota 
(western Dickey County), central Minnesota (Otter Tail and Hennepin Counties), southern Wisconsin (Jamesville, Madison, Racine), central Michigan (Saginaw Bay), southern Ontario (St. Clair Flats to Toronto), and New York (Buffalo, Branchport, Ithaca, Long Island), to Massachusetts. The western boundary extends from southeastern North Dakota, eastern Nebraska, western Kansas (Cheyenne and Meade Counties), and central Oklahoma, to southern Texas (Corpus Christi). Collections of specimens at Brownsville, Tex., on September .27, 1911, and April 2 (year not given) (Griscom and Crosby, 1925, p. 527) suggest the possibility of breeding in that area. The eastern boundary extends from Massachusetts southward along the Atlantic coast to the southern Everglades. The southern boundary includes the gulf coast region, in places virtually to the edge of the gulf itself.

Records of occurrence near or beyond the limits of the normal breeding range are as follows: St. John's, Newfoundland (October 20, 1935) ; Wellington, Prince Edward Island, Canada (March 28, 1917); Ottawa, Ontario (May 7, 1896) ; Crane Lake, Ontario (July 31,1931 ) ; Port Perry, Ontario (April 21, 1923) ; Bucksport, Maine (November 22, 1909) ; Fargo, N. Dak. (October 15, 1925) ; Key West, Fla. (November 2, 1895); Dry Tortugas, Fla. (May 1961) (W. B. Robertson, personal communication); and Tlacotalpan, Veracruz, Mexico (January 18, 1901).

The King Rail's principal wintering range coincides with that part of the breeding range where the species is most abundant, in the tidewater country from the Delaware Valley to southeastern Georgia, and southward through interior Florida into the Everglades, westward through the gulf coast marshes and the rice belts of Louisiana and Texas, and north into the Arkansas rice belt.

The King Rail is a regular winter resident along the Atlantic coist as far north as New York City and in the Mississippi Valley to southeastern Missouri. Southernmost winter records in the United States are from the Lower Rio Grande Valley, in the vicinity of Brownsville, Tex. (December 28, 1911, and January 10, 1923) (Griscom and Crosby, 1925, p. 527).

Some of the numerous winter records (mainly from the distribution files of the Section of Migratory Non-Game Bird Studies, Migratory Bird Populations Station, Laurel, Md.) north of the principal winter range are as follows: LaSalle, Ontario (December 15, 1930) ; Lorne Park, Toronto, Ontario (December 26, 1960) ; Falmouth, Maine (December 17, 1899) ; Cambridge, Mass. (December 30, 1896); Cape Cod, Mass. (December 30, 1951); Hillsdale, Mich. (December 11, 1896); Detroit, Mich. (February 6, 1907); Port Huron, Mich. (December 6, 1902); Vicksburg, Mich. (February 6, 1909) ; Prudensville, Mich. (December 7, 1938); Monroe County, 
Mich. (December 30, 1934, and February 8, 1934); Bayside, Long Island, N.Y. (December 24, 1924) ; Miami and Meade Counties, Kans. (late December) ; and Montauk Point, Long Island, N.Y. (December 27,1951 ).

In the New York City region, Bull (1964, p. 169) reported 15 winter speoimens, 5 in December, 7 in January, 1 in February, and 2 the first week in March. Eleven of the fifteen were taken in salt marshes, and there were 19 sight records in salt marshes, nearly all in December and January.

On the basis of extensive field observations by several ornithologists, including Robert E. Stewart, Milton B. Trautman, D. J. Nicholson, T. D. Burleigh, Oliver H. Hewitt, and myself, and as a result of an intensive literature review, the most important areas of concentration probably have been determined.

The King Rail occurs in greatest numbers in the vast coastal marsh and ricefield area of southern Louisiana. Other areas supporting high populations include the coastal marsh-rice belt of Texas; the Arkansas rice belt; the fresh and brackish tidal marshes of the Carolinas and Georgia; the Everglades, the Kissimmee Prairie, and the St. Johns River marshes of Florida; and the tidal marshes of the Delaware Valley and Chesapeake Bay. The Lake Erie marshes of northern Ohio and the St. Clair Flats opposite Detroit, Mich., are two important concentration areas in the North Central States.

\section{MIGRATION}

Throughout most of its range the King Rail is migratory. Evidence of movements between wintering and breeding grounds is based on recoveries of banded birds, and birds heard calling overhead at night, striking beacons, and appearing in odd places such as city streets during periods of migration.

The Atlantic Coastal Plain, particularly its outer section, and the Mississippi Valley are important flyways of the King Rail. The occurrence of King Rails near the Atlantic coast during migration is due to movements to and from breeding grounds in that area. King Rails commonly breed at many places less than 50 miles from the coast. Several known localities include Butler Island near Darien, Ga.; Savannah National Wildlife Refuge, Jasper County, S.C.; Georgetown, S.C.; Currituck Sound, N.C.; Norfolk, Va.; the coastal sea islands and Delaware Bay marshes.

A King Rail collected by I. N. Gabrielson in the Atlantic coast salt marshes at Wachapreague, Va., August 25, and several taken by hunters in September at Chincoteague, Va., indicate the probable route of migration of at least some northeast Atlantic coast breeding birds.

During 7 years' residence in the lower Mississippi Valley, I heard migrating King Rails regularly every spring at Alexandria, La., and 
Stuttgart, Ark. On the night of March 11, 1956, single King Rails were heard calling as they migrated northward over the city of Alexandria at $8: 30,9: 30$, and 11 p.m. They appear to be less vociferous while migrating in the fall. The most commonly uttered call of migrating King Rails is a chur-r-r-r-r (the $r$ like the German "R"). Another call occasionally given is chac-chac-chac-.

Probably most fall migration takes place after molting, which is completed about the first of September. In Delaware, I have collected flightless birds in the last week in August that would still have been flightless through the first week in September. However, some rails collected in late August had nearly or completely renewed their flight feathers.

The fall departure schedule for three species of rails at the $\mathrm{Pa}$ tuxent Wildlife Research Center, Laurel, Md., was determined by a trapping and banding program extending from midsummer to early winter. King Rails were the first to leave the area (the last by late September) ; they were followed by Soras (the last by early November), and lastly by Virginias (the last of December).

David C. Hulse (personal communication) wrote that a definite influx of King Rails is noticed annually at Decatur, northern Alabama, in late September: "Local birds are still here and at this time must be augmented by migrants. Departure is gradual and by late October rails become gradually scarce."

King Rails breeding at the southern limit of their range in the gulf coast region are probably permanent residents or may perform short coastwise migrations.

Winter records for the Middle Atlantic and North Central States suggest the possibility of permanent residency by some individuals. In the Chesapeake Bay region of Maryland there are two records of King Rails banded in August and recovered in the same marsh the following January. Also, a 6-week-old chick banded July 12, 1968, at the Patuxent Wildlife Research Center, Laurel, Md., was recovered December 12,1968, at the same place.

As of January 1966 there have been only two recoveries of King Rails that migrated an appreciable distance from the point of banding. Only one of these was a direct recovery (bird recovered within 12 months of banding date). A 2-week-old chick was banded at Stuttgart, Arkansas County, Ark., on June 2, 1952, and recovered at Cut Off, Lafourche Parish, La., Decomber 1, 1952, having traveled a distance of about 350 miles. The other recovery concerned a King Rail banded at Lassie, Wharton County, Tex., June 9, 1949, and recovered at Brookville, Montgomery County, Ohio, 1,000 miles away, on May 2, 1951. A King Rail banded at Ruthven, Palo Alto County, Iowa, August 25, 1951, and recovered at Lake View, Sac County, Iowa, 
September 10, 1951, had traveled some 60 miles and was probably migrating.

Spring arrival and fall departure dates are given in table 2. Some of these dates are questionable; those for the interior northern part of the range may be more reliable than those along the Atlantic coast where so many King Rails winter.

\section{LOCAL MOVEMENTS}

Information on local movements was obtained at two marshy impoundments at Patuxent Wildlife Research Center, Laurel, Md., during the summers of 1965 and 1966. In 1965, four pairs of King Rails nested in an impoundment known as Knowles Unit 2; in 1966, no King Rails nested there because of deep water. Knowles 2 has an area of 20 acres, of which about 10 acres are shrub swamp or marsh or a mixture of the two. Knowles Unit 1, the other impoundment, is larger, but contained only about 6 acres of marsh and shrub swamp at the time. One pair of King Rails nested there in 1965 and 1966.

TABLE 2.-Spring arrival and fall departure dates for migrating King Rails

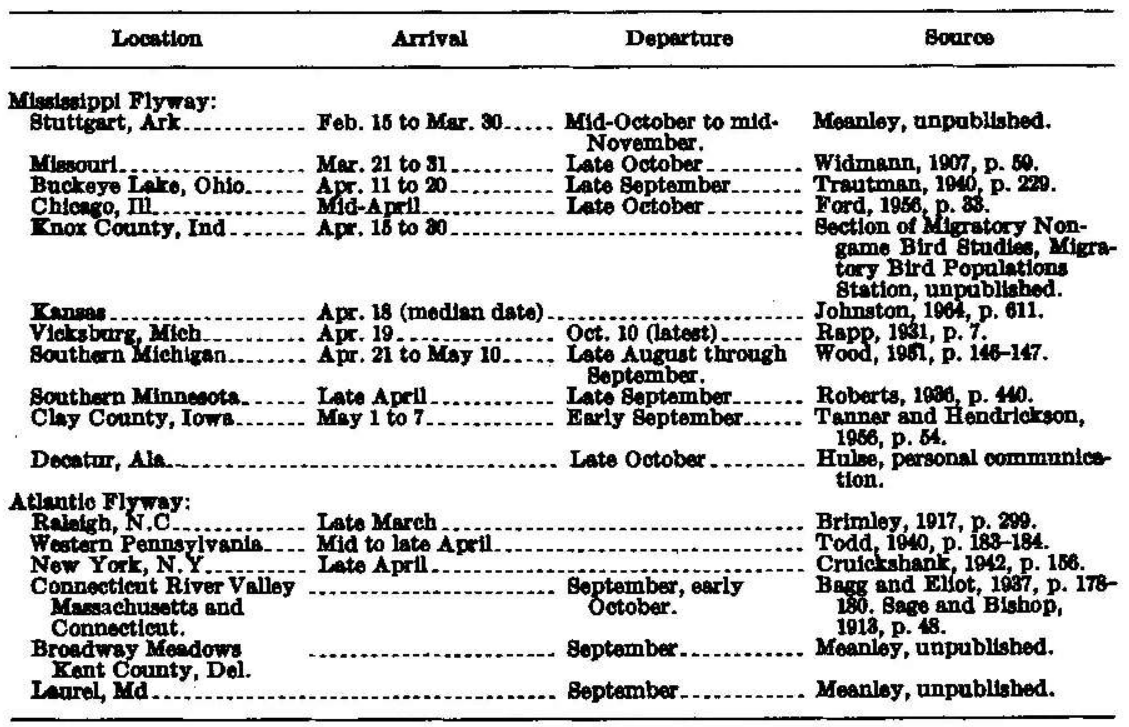

One of a pair of nesting King Rails trapped and banded on June 12, 1965, in Knowles 2, was first recaptured on August 2, approximately 200 yards from where it was banded. This bird was recaptured a second time on August 7, approximately 350 yards from the second site and 500 yards from the original site.

The young of the 1965 nest in Knowles 1 were hatched on July 2 and 3. Earlier, one of the adults was banded and color-marked while incubating. Both adults and the brood remained within 100 feet of the nest most of the time until at least July 24 , a period of 3 weeks. 
On July 8,1966 , the same color-marked adult, its mate, and their brood of eight 2-week-old chicks were trapped in Knowles 1, 50 feet from where the color-marked adult had nested the previous year. The unbanded adult and the chicks were banded when trapped.

On July 16, two of the eight chicks were captured and the rest of the family was observed on an island in Knowles 2, 0.4 mile from the site of their original capture in Knowles 1 on July 8. To reach the island in Knowles 2, the 3-week-old flightless chicks had not only walked nearly half a mile but had swum across 50 feet of open water that had a depth of 3 feot. 


\section{Ecological Relations}

The King Rail probably occurs in a wider variety of habitats than any other rail. The species ranges from coastal salt and brackish marshes to shrub swamps and occasionally is found even in upland fields near marshes where it forages for grasshoppers and grain, and where it sometimes nests.

The distribution of the King Rail's habitat coincides rather closely with that of the muskrat (Ondatra zibethicus). Muskrats create optimum habitat for rails by opening up marshes and producing networks of pathways leading to plunge holes. When the tide goes out, water is trapped in the holes, and rails use them as drinking places. Muskrat trails are also favorite places for crayfish burrows. The crayfish are a prime food of the rails and are usually carried to the tops of muskrat houses for eating.

Because of the geographic as well as the local variation in habitats of the King Rail, the ecological relations will be discussed on a regional basis.

This chapter will cover both my own observations on the ecology of the King Rail in Louisiana, Arkansas, South Carolina, Delaware, and Maryland, and those of other authors in different States or areas.

\section{LOUISIANA GULF COAST MARSHES}

The King Rail and the Louisiana Clapper Rail, a brownish form virtually indistinguishable from the King Rail in the field, occur together in some sections of the Louisiana coastal marsh. This vast marsh area of more than 4 million acres is divided into three major divisions, each of which is a distinct habitat type and will be discussed separately : the delta marsh, subdelta marsh, and prairie marsh (St. Amant 1959, p. 97-101) (fig. 4).

\section{The delta marsh}

The delta marsh, near the mouth of the Mississippi River, comprises only 7 percent of the total coastal marsh area of Louisiana. Important plant species of the delta marsh are caltails (Typha spp.), roseau cane or reed (Phragmites communis), common three-square (Scirpus americanus), dog-tooth grass (Panicum repens), giant cutgrass (Zizaniopsis miliacea), saltmarsh cordgrass (Spartina alterniflora), delta duck potato (Sagittaria platyphylla), alligatorweed (Alternanthera philoxeroides), and water hyacinth (Eichhornia crassipes). 


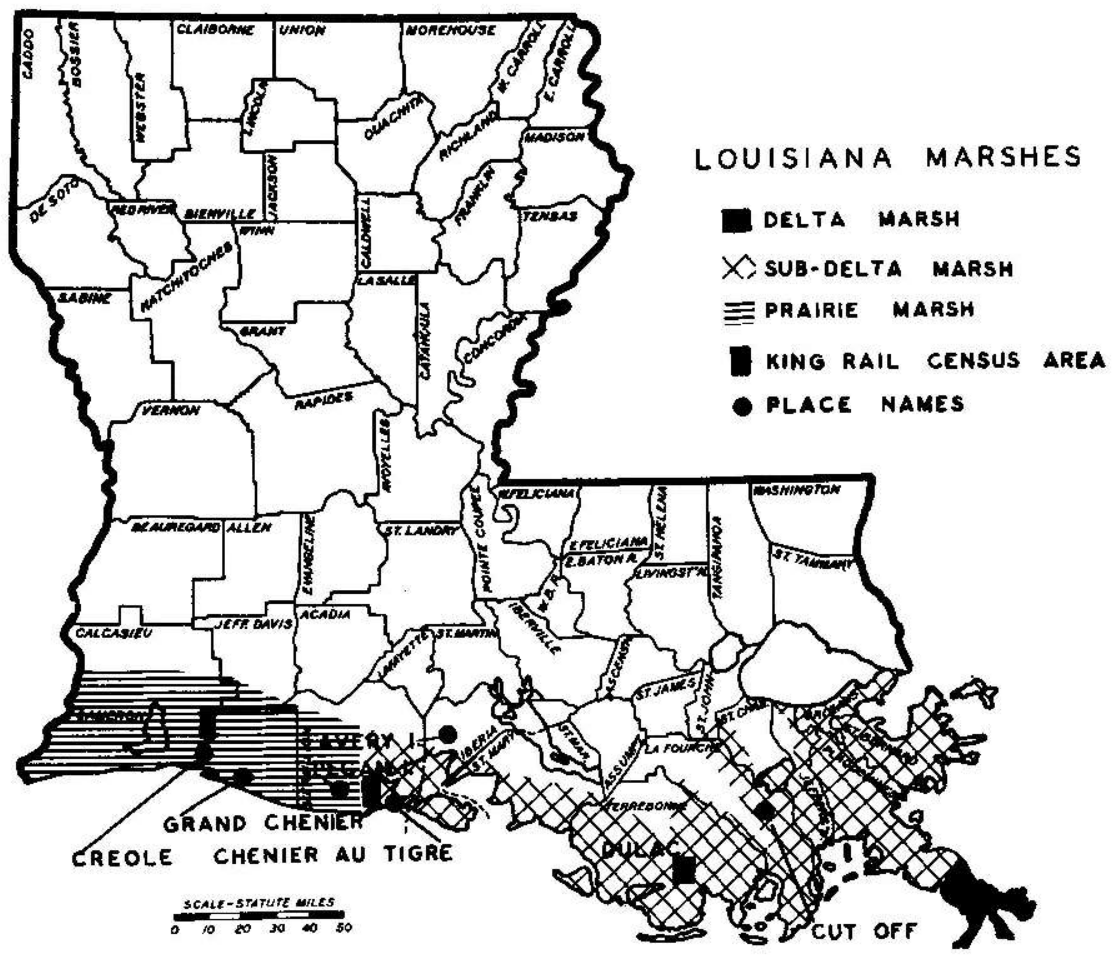

Fiourn 4.-Louisiana gulf coast marshes.

Oberholser $(1938$, p. 109, 201) reported the collection of a King and six Clapper Rails in the delta marsh at the mouth of the Mississippi River, indicating their presence in this habitat type.

\section{The subdelta marsh}

The subdelta marsh, comprising 74 percent of the Louisiana coastal marsh, extends westward from the Mississippi River Delta to Cow Island and Chenier au Tigre in Vermilion Parish. Both its fresh-water and brackish marshes are of two types, floating or with a firm floor of clay. The predominant plant species in both types is "paille fine" or maidencane (Panicum hemitomon). Associated with it are cattail, southern bulrush (Scirpus californicus), sawgrass (Cladium jamaicense), wapato (Sagittaria latifolia), alligatorweed, and water hyacinth. In brackish areas either saltmeadow cordgrass (Spartina patens) or Olney's threo-square (Scirpus olneyi) is dominant; the latter is dominant if there is management (burning) for muskrat production. Salt marshes in this area are dominated by needlerush (Juncus roemarianus), saltmeadow cordgrass, and saltmarsh cordgrass.

Both banding returns and collections of birds substantiate the occurrence of King Rails in the subdelta marsh. A King Rail banded at Stuttgart, Ark., in June 1952, was recovered at Cut Off, Lafourche 
Parish, in the subdelta marsh, in December 1952. Cut Off is approximately 25 miles south of New Orleans. King Rails were collected at Chenier au Tigre, January 1,3 , and 5,1934 , by A. M. Bailey (Oberholser 1938, p. 199); at the same location on March 31 and April 1, 1947, by I. N. Gabrielson; and at Avery Island, May 7, 11, 13, and 15, 1930, by E. G. Wright (Oberholser, 1938, p. 199).

I made a census, based on calls, in Terrebonne Parish, 1.2 miles south of Dulac, on January 3, 1963, to determine the abundance of King Rails in the area (table 3). The birds were heard calling from what appeared to be an abandoned silted-in canal where shallow ponds were interspersed with dense patches of vegetation dominated by clump grass (Spartina spartinae). In a 1-mile strip, 50 feet wide, 19 King Rails were counted. Short-billed Marsh Wrens (Cistothorus platensis), Soras, Virginia Rails, and Common Gallinules (Gallinula chloropus) were also common in this same census strip.

\section{The prairie marshes}

The prairie marshes in the southwestern part of the Louisiana gulf coast (Vermilion and Cameron Parishes) comprise 19 percent of the total area. Near the gulf coast much of the prairie marsh is bisected by ridges known as cheniers (stranded rims of the sea or old shoreline) that parallel the coast (fig. 5). Cheniers extend in straight lines for many miles and in most places are wide enough only for a

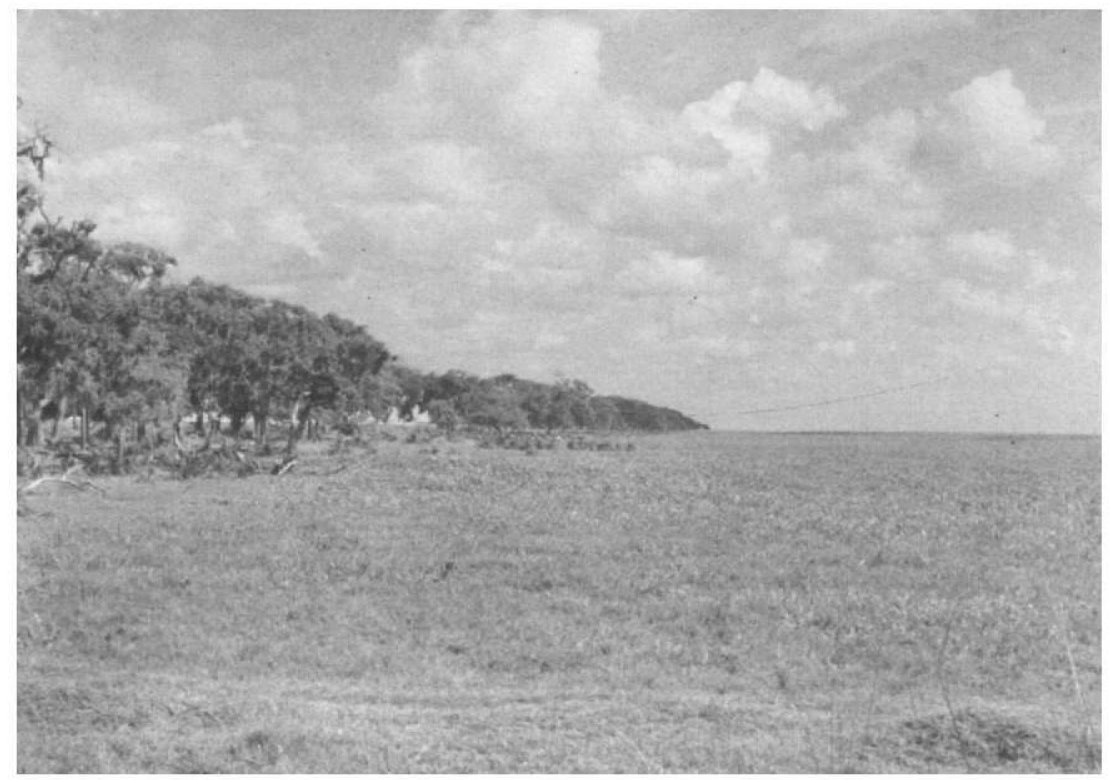

Frouex 5.-Prairie margh, Grand Chenier, La., March 1956. Mixed King and Clapper Rail populations sometimes occur in the same marsh type in this area. Both species were collected from the same half-acre pool near here, April 1056. 
road bordered on each side by a line of live oaks. In some places there are a few houses. In some sections, cheniers separate fresh and brackish marshes.

TABLE 3.-Abundance of King Rails in certain areas, as indicated by censusing

\begin{tabular}{|c|c|c|}
\hline Loestion & Number of K/ng Rails & Cover type \\
\hline 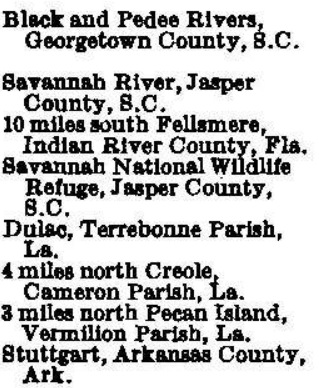 & 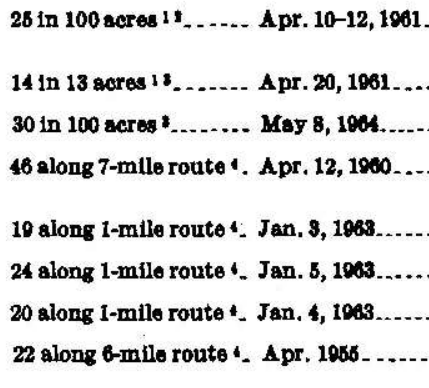 & $\begin{array}{l}\text { Giant cutgrass, cattsil, } \\
\text { big cordgrass, arrow. } \\
\text { arnm, } \\
\text { softstem bulrush. } \\
\text { Maidencane. } \\
\text { Giant cutgrass, cettall, } \\
\text { sawgrass. } \\
\text { Clump grass, or needle } \\
\text { cordgras. } \\
\text { Fall panicum. } \\
\text { Fall panicum. } \\
\text { Rice stubble, broom- } \\
\text { sedige, cattail, softrush. }\end{array}$ \\
\hline
\end{tabular}

1 Males only.

2 Two-etsere sampling.

- Strip consus.

- Roadside count.

In this area salt marshes near the coast are dominated by a saltgrass-saltmeadow cordgrass-saltmarsh cordgrass association. Landward from this association, brackish marshes extend north to the Creole and Grand Chenier ridges. Principal plants of the brackish marsh are saltmeadow cordgrass, Olney's three-square, and saltmarsh bulrush (Scirpus robustus). In the transition areas between brackish and fresh water, such plants as giant cutgrass, bull tongue, pickerelweed (Pontederia cordata), and wild millet (Echinochloa crusgalli) grow. The fresh-water marshes lie mainly north of the Grand Chenier and Creole ridges. In the higher parts of those marshes the following plants are found : bull grass (Paspalum boscianum), lake grass (Paspalum distichum), dotted smartweed (Polygonum punctatum), squarestem spikerush (Eleocharis quadrangulata), and delta duck potato. Sawgrass is the climax type in the lower parts of the freshwater marsh.

In the vicinity of the cheniers, King and Clapper Rails occur close to one another or together. Referring to this situation, Lowery (1955, p. 227) made the following statement:

The King and Clapper Rails are extremely similar in appearance and are, for the most part, simply ecological representatives of each other. The former generally inhabits fresh-water marshes and is widespread in the friterlor of the United States; the latter is always found on or near the seacasst in brackishor salt-water marshes. ... There are brackish marshes in which both breed side by side without intermingling ; . . .

I find it difficult to believe that the two species do not interbreed in the prairie marshes. Several King-Clapper pairs (and their nests and 
eggs) have been collected recently in Delaware brackish marshes, indicating that they do sometimes interbreed when they occur together (Meanley and Wetherbee, 1962, p. 453-457).

Near the village of Grand Chenier, I collected both Kings and Louisiana Clapper Rails from the same small pond on the south side of the chenier. The dominant vegetation in the immediate area was clumpgrass. On the south side of this narrow chenier, in the brackish marshes, the gulf coast form of the Clapper Rail is the dominant species, but the marsh on the landward side is the King Rail's domain. Rivers, such as the Mermenteau, and canals crossing the chenier extend the brackish water landward, and occasionally storm tides also affect large areas of the marsh, extending salt water into the freshwater zone and changing the habitat. This area may well be described as a mixing ground of plants and animals. A common avian associate of the rails breeding in the clumpgrass and saltgrass marsh was the Mottled Duck (Anas fulvigula).

I also encountered four King Rail broods, still in downy black plumage, and three single adults 4 miles north of Grand Chenier on July 23, 1955. At this station the marsh was composed of a mixture of southern bulrush, cattail, a Sagittaria, probably lancifolia, and water-hyacinth.

A census of King Rails, based on calls, was made in a marsh bordering the Pecan Island road, 2 miles south of the old Intracoastal Canal, Vermilion Parish, on January 4, 1963. Twenty birds were counted in 20 minutes along a 1-mile strip approximately 200 yards wide, at 6 p.m. (table 3). The dominant vegetation in the census area was fall panicum (Panicum dichotomiflomum). A similar census was made 5 miles south of the Intracoastal Canal on the east side of the road to Creole, Cameron Parish, on January 5, 1963. Between $5: 30$ p.m. and 6 p.m. 24 birds were counted along a 1-mile strip approximately 200 yards wide (table 3 ). The dominant vegetation types in the area were southern bulrush and fall panicum (fig. 6 ). Soras were also abundant in the same habitat.

\section{SOUTHERN RICEFIELDS}

The gradual shift in the domestic rice (Oryza sativa) growing industry from the South Atlantic coast to the South Central States of Louisiana, Texas, Arkansas, and Mississippi after the Civil War opened up a new marsh habitat for King Rails and other water birds. Much of the land where rice is grown today was once a vast natural tall-grass prairie in which the Greater Prairie Chicken (Tympanuchus cupido) was abundant. Harmon, Thomas, and Glasgow (1960, p. 153) reported that approximately 3 million acres in this area were devoted to rice growing by 1958 , and that this acreage wintered 4 million ducks and geese. Many aquatic plants grow in ricefields, and 


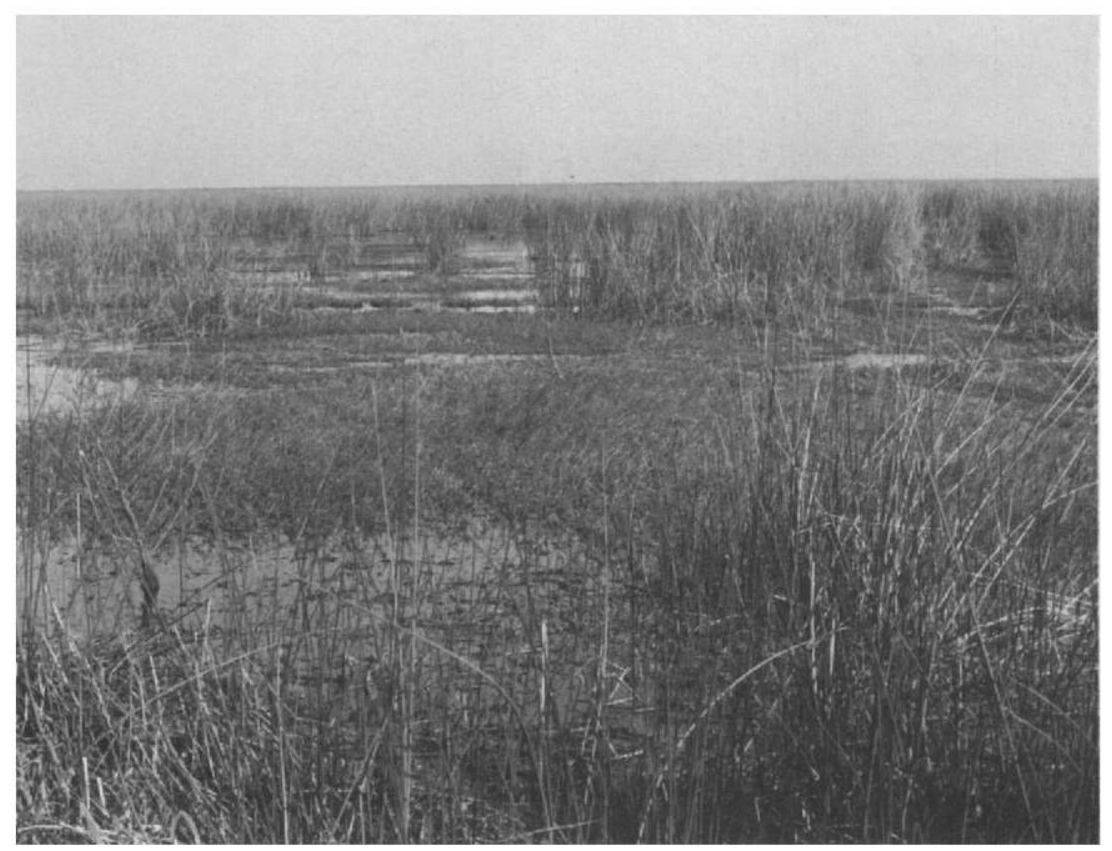

Fraure 6.-Southern bulrush (Scirpus californicus), fall panicum (Panicum dichotomiflorum), and alligatorweed (Alternanthera philoxeroides) in prairie marsh type near Creole, Cameron Parish, La., January 5, 1965. Between 5 :30 and 6 p.m., January 5, 1963, 24 King Rails were counted along a 1-mile transect through this marsh.

virtually all produce seeds utilized by a variety of water birds. Ricefields furnish an optimum all-purpose habitat for King Rails for nearly 6 months during the summer half of the year, and a source of food for them in winter (fig. 7).

On the gulf coast prairie of Louisiana and Texas, rice planting begins in March. Some early varieties are harvested by late July, but most fields are harvested from early August to early October. The planting season in Arkansas is about 2 weeks later, and harvest is from late August to early November. The fields are irrigated by wells or by canal systems fed from reservoirs or bayous. Water remains on the fields for 3 or 4 months and is maintained at a constant level of from 6 to 10 inches.

On the Arkansas Grand Prairie I found the nesting density of King Rails in one ricefield to be at least one nest per 15 acres, a figure based on the location of five nests in a 75-acre field in July. These nests were located by a team of men walking abreast and systematically covering the field to remove a pest plant, the coffeebean (Sesbania exaltata). The height of the nesting season was several months past, and these nests probably represented a renesting effort or a second 


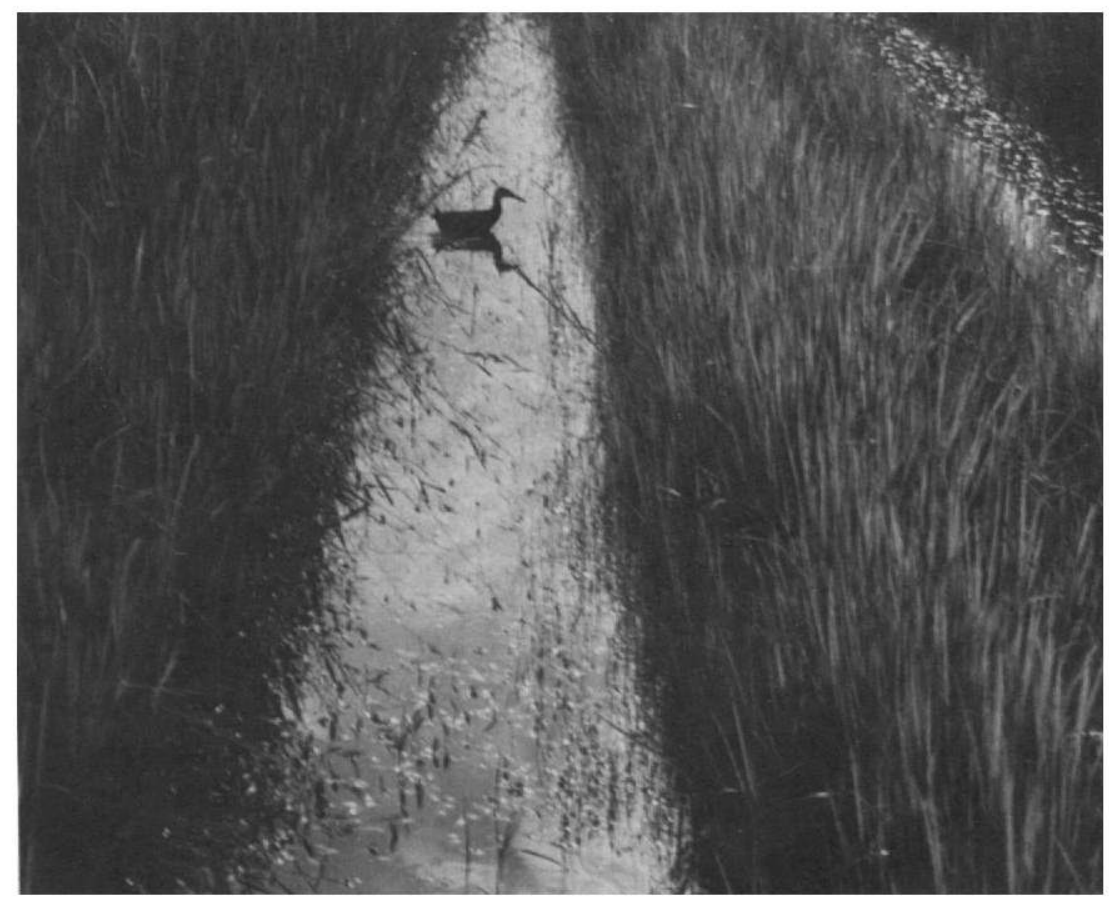

Froura 7.-King Rail wading through ricefield toward nest on dike, Stuttgart, Ark., July 13, 1962.

nesting after an earlier first successful nesting. It is not to be construed that this is an average nesting density for Grand Prairie ricefields.

Since much of the rail nesting in rice country is completed before the rice is high enough to provide nesting cover, a better idea of nesting density could be obtained from nest counts or mating call counts in the spring when most of the rails are found in roadside ditches and canals and occasionally in rice stubble. As an example, in April 1955 I located 22 occupied nesting territories along 6 miles of continuous roadside ditch beginning 2 miles north of Stuttgart, Ark. (table 3 and fig. 8).

In Evangeline and Jefferson Davis Parishes in Louisiana I found many nests in roadside ditches where the dominant regetation was paille fine (maidencane) and softrush (Juncus effusus). In Arkansas Grand Prairie ditches in 1952 and 1953, nests were found mainly in stands of softrush, cattail, common spikerush (Eleocharis palnustris), and lake sedge (Carex hyalinolepis and $C$. lacustris), a plant which grows to a height of 3 feet or more and forms very dense stands that persist intact through the winter. Lake sedge was available for nesting cover earlier than any plant in the roadside ditches. Ten years 


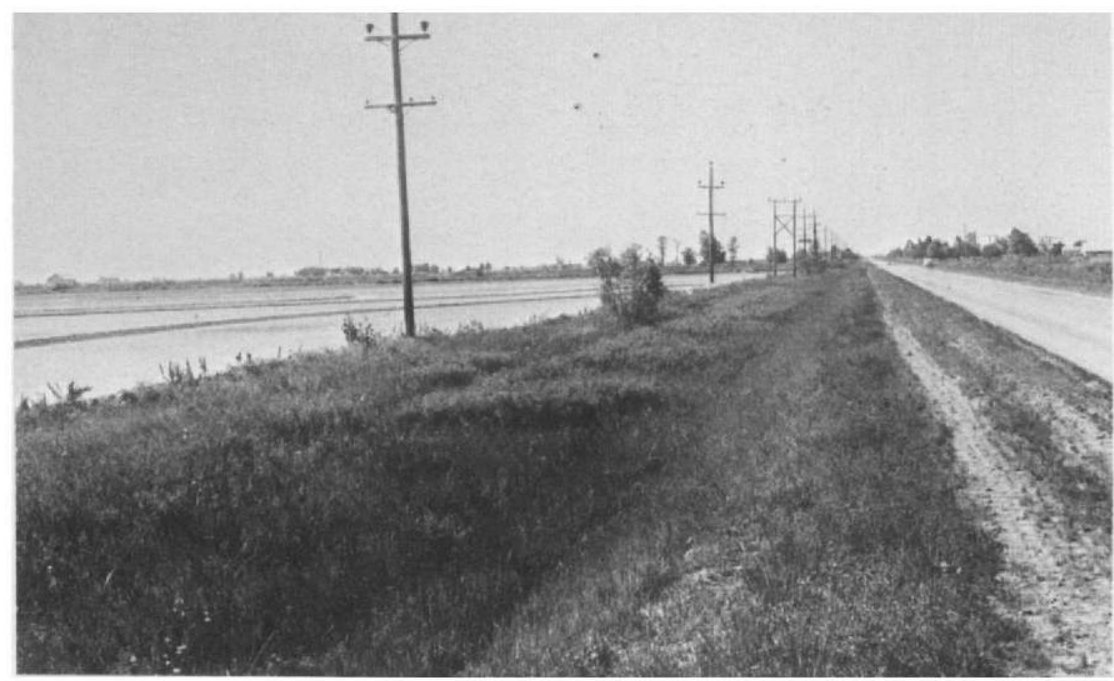

Frougs 8.-Arkansas Grand Prairie near Stuttgart, Ark, May 1962. Ralls nest in roadside ditches in April and May. Vegetation in ditches is mostly softrugh (Juncws effusus) and two pedges (Cares stipata and C. hyalinolepis). In June, rails move into ricefields (left of ditch) for late nesting or renesting as rice begins to form nesting cover.

later (1962), in those same ditches, awl-fruited sedge (Carex stipata) was the dominant plant, and four of six nests located during May of that year were constructed of this plant.

Old rice stubble is sometimes used for nesting. On the southwestern Louisiana rice prairie where farming is less diversified than on the Arkansas Grand Prairie, many farmers let the stubble fields lie out through the winter and spring for cattle grazing. In one such wet stubble field at Mamou, Evangeline Parish, I located two rice-straw nests on May 5, 1957 (fig. 9).

During the summer, when the rice is growing and the fields appear as a vast green marshland, virtually all King Rails in the rice belt frequent the fields. Some are renesting, and others are wandering about with their broods in search of crayfish, minnows, and aquatic insects which abound here.

Nesting associates of the King Rail in Louisiana ricefields are the Fulvous Tree Duck (Dendrocygna bicolor), the Purple Gallinule (Porphymula martinica), the Least Bittern (Ixobrychus exilis), and along the southern border of the rice belt the Mottled Duck. The most common bird in the area is the Red-winged Blackbird (Agelains phoeniceus). In the northern part of the principal Louisiana rice belt, at Mamou, Evangeline Parish, I found the Long-billed Marsh Wren (Telmatodytes palustris) nesting in rice. 


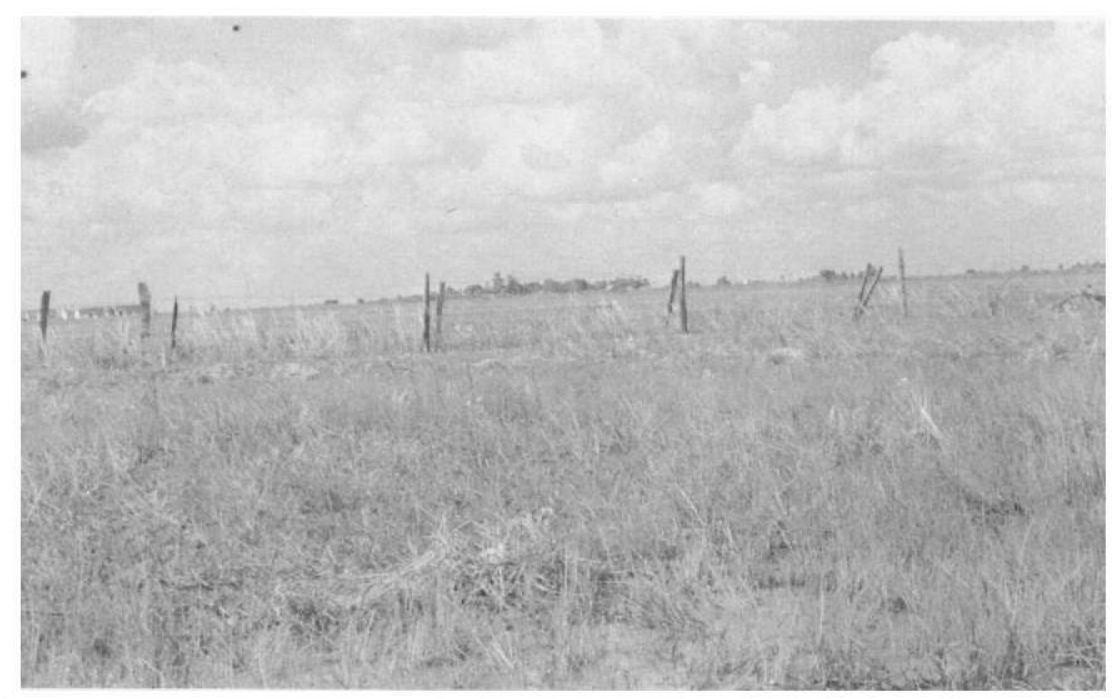

Frouke 9.-Nest of King Rail in wet rice stubble, Mamou, La., May 5, 1957. Photographed as found.

In 1955 a rice farmer at Mamou located six Fulvous Tree Duck nests in a 400-acre block of rice, and in the same locality I found 22 active Purple Gallinule nests in a 10 -acre section of a 25 -acre ricefield. In the Arkansas ricefields the Purple Gallinule is an uncommon breeding bird. There are no breeding records for the Fulvous Tree Duck in Arkansas ricefields, but there are several early fall occurrence records. The Short-billed Marsh Wren has been found nesting in Arkansas ricefields in August and September.

King Rails are more secretive in winter than at other seasons and often are present in good numbers in some localities although seldom or never seen. For 5 years in the Arkansas rice belt, I was in the field daily without ever seeing one in the dead of winter. Yet they were present, as a mink trapper brought me several each January.

On the Arkansas Grand Prairie, I have often come across trails forming tunnels which often continue for many feet beneath the matted vegetation of a ditch bank. These trails appear to have been made by some mammal, yet many tell-tale signs, particularly the characteristic regurgitated pellets and roundish droppings about the size of a silver dollar, are proof that King Rails use them. Regardless of whether these trails are made by rails, mink (Mustela vison), rabbits (Sylvilagus floridanus), or rats (unidentified), trapping indicates that they are used by all four species. King Rails also spend the winter in small marshy tracts along the bayous that dissect the Grand Prairie.

At Stuttgart, Ark., a King Rail used a long water pipe about 11/2 feet in diameter and running from a pumphouse to a small reservoir 
as its winter retreat. From late November to mid-December, I stopped by almost daily to see its fresh tracks leading from the pipe to the mudflat of the reservoir.

A rather surprising wintering habitat is the cutover longleaf pine (Pinus palustris) land of central Louisiana. Bobwhite and Woodcock hunters flush King Rails from little damp spots or seepage areas in the bluestem (Andropogon tener and $A$. divergens) range. Crayfish, a prime food of the rail, also are found there.

\section{FLORIDA}

A. H. Howell $(1932$, p. 202), in commenting on the status of the King Rail in Florida during the early 1930 's, said it was probably most numerous in the Everglades and big marshes of the upper St. Johns River. D. J. Nicholson of Orlando (personal communication, 1962), who has made an intensive study of Florida birds since 1900, told me the King Rail is still a common to abundant breeding bird in many parts of central and southern Florida, although extensive drainage projects in the area have destroyed thousands of acres of marsh habitat. In addition to the two areas mentioned by Howell, Nicholson included the open wetlands of the Kissimmee Prairie as an important King Rail area. $\mathrm{He}$ added that the King Rail is common in the St. Johns River marshes in Seminole, Orange, Volusia, Brevard, and Indian River Counties; and is found in good numbers nesting on Merritt Island, Brevard County, "both in the salt marshes near Wayne's Clapper Rail, as well as in numerous fresh water ponds on that island."

S. A. Grimes (personal communication) reports that, in northern Florida, the King Rail occurs in most of the fresh-water marshes of Duvall County. Two of the several nests he found were in open cypress bayheads.

A. D. Cruickshank (personal communication), in writing from Brevard County, said that the King Rail is decidedly more common there in winter than during the breeding season, with peak numbers usually coming in late December and January. Apparently the local population is augmented by migratory populations from north of Florida. Evidence of local abundance in this area is based on the annual Audubon Society Christmas bird count conducted within a 15-mile radius of Cocoa, Fla. (Cruickshank et al., 1953-66). The numbers of King Rails reported has ranged between 11 and 93 over the past 14 years and averaged 40 per year. Cruickshank reports that the best localities are $(a)$ fresh-water marshes around Lake Poinsett, a large lake in the St. Johns River, and $(b)$ fresh-water marshes on Merritt Island.

During the period May 4-8, 1964, I examined some marshes in Indian River, Osceola, and Glades Counties. Approximately 10 miles south of Fellsmere, Indian River County, at the junction of State 
Highways 60 and 512, I found King Rails common where maidencane and pickerelweed formed a high percentage of the vegetation of the wetter marshes (fig. 10). Apple snails (Pomacea pahudosa), the

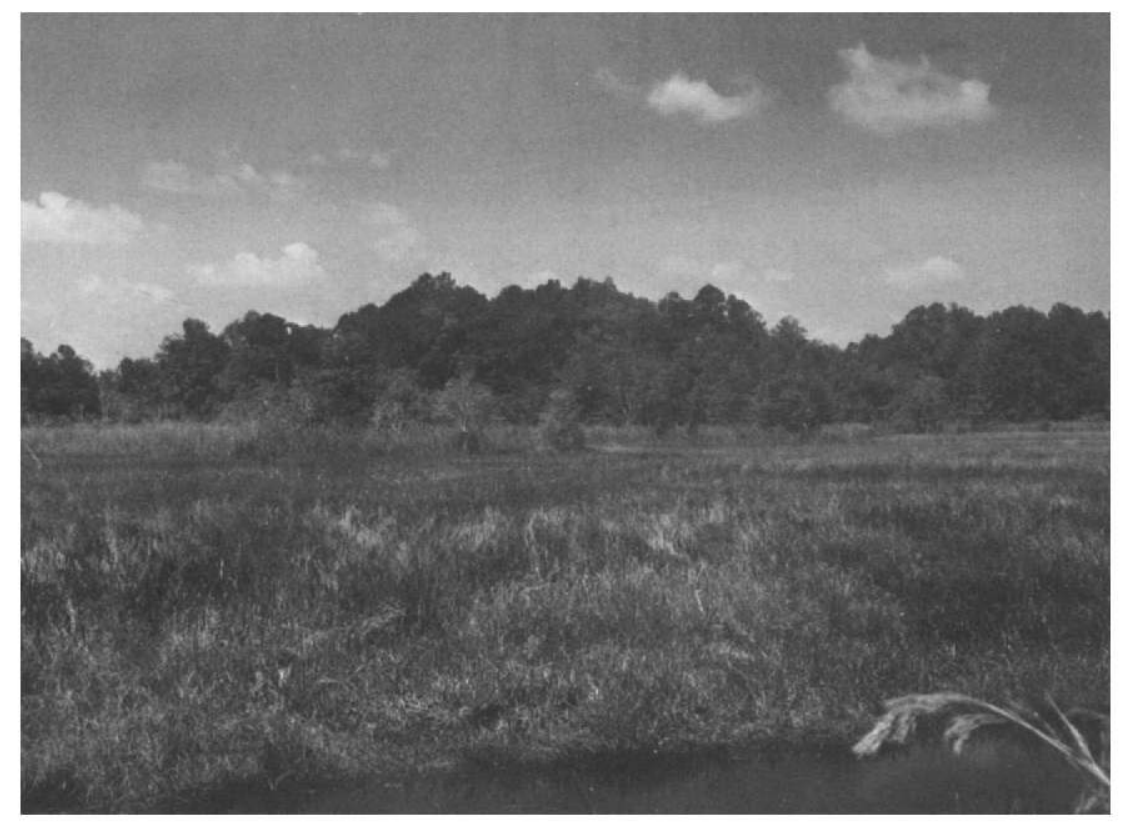

Frauke 10.-Fabitat of King Rail, 10 miles south of Fellsmere, Indian River County, Fla., April 1967. Marsh vegetation in foreground is mostly maidencane (Panioum hemitomon) and pickerelweed (Pontederia cordata), in background sawgrass (Cladium jamaicense). White waterlily (Nymphaea odorata) in pond left of center. Forest community is pond cypress (Tacodium ascendens). The density of King Rails in this area was estimated at 30 birds per hundred acres.

major food of the Limpkin (Aramus guarauna), and the eggs of these snails, were scattered abundantly throughout the wetter marshes, but were absent from the drier ones. 'Houses of the round-tailed muskrat (Neofiber alleni) were abundant in both wetter and drier marshes. Limpkins and rails use the tops of these houses as their "dinner tables." King Rails were most commonly in the drier marshes. I estimated a density of approximately 30 birds per hundred acres in a tract on the east side of Highway 512 (table 3).

On the Brighton Seminole Indian Reservation, Glades County, I heard and saw King Rails in marshes composed largely of pickerelweed, bull tongue (Sagittaria lancifolia), and dotted smartweed (fig. 11). While on a trip through the reservation in January 1958 , I saw two very dark-plumaged King Rails in a small pickerelweed marsh. 


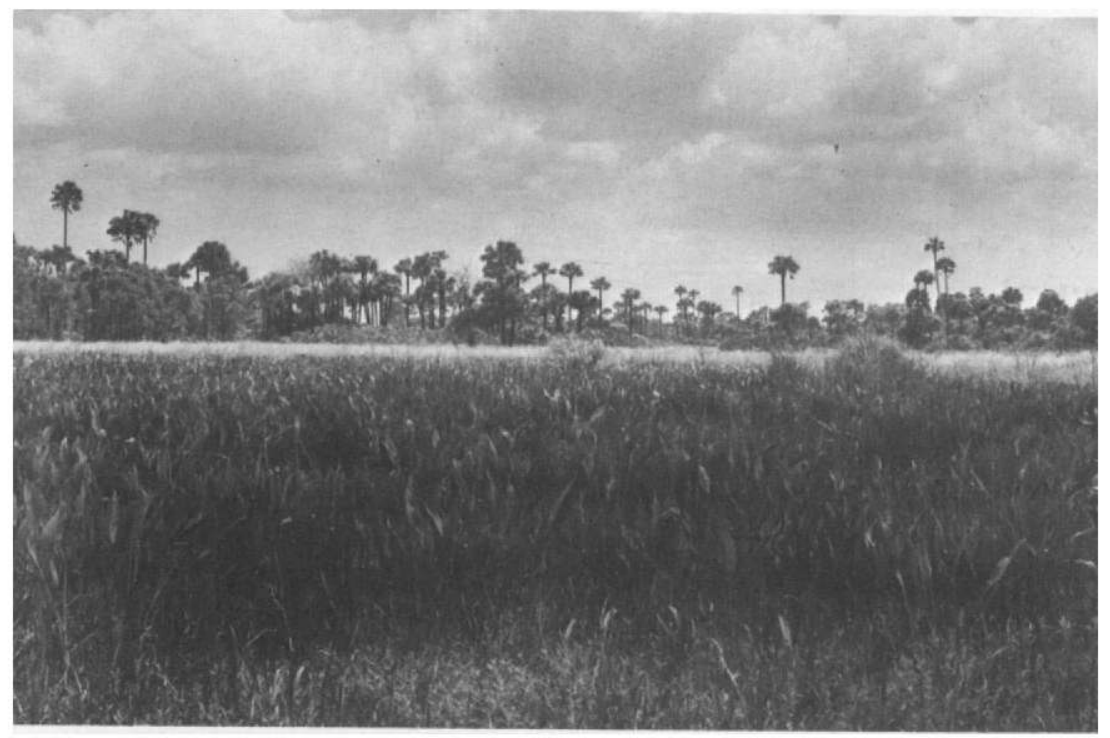

Frauke 11.-King Rail habitat on Seminole Indian Reservation, Glades County, Fla., May 5, 1964. Predominant plants in marsh are bull tongue (Sagittaria lancifolia), pickerelweed (Pontederia cordata), and dotted smartweed (Polyoonum punctatum).

\section{SOUTH GAROLINA LOW COUNTRY}

King Rails are common to abundant in many fresh-water and brackish tidal-river marshes of the South Carolina Low Country. These marshes are along the famous rice rivers of colonial times: the Ashepoo, Black, Combahee, Edisto, Pee Dee, Santee, Savannah, Waccamaw, Wando, and others. It was in such marshes that domestic rice was grown until about 1915. Remnants of the old ricefield dikes and canals built by slaves are still evident in the marshes (fig. 12).

The dominant vegetation type of most sections of the marshes today is giant cutgrass. Because of the blanched appearance of the giant cutgrass in winter, these marshes were referred to by the early explorer-naturalists as the "white marsh." Giant cutgrass provides excellent escape and nesting cover for rails but apparently is of no food value to them, although Purple Gallinules, Red-winged Blackbirds, and Bobolinks (Dolichonyx oryzivorus) feed on its flowers and seeds.

A survey of the marshland in the Low Country from the lower Cape Fear River at Wilmington, N.C., to the Altamaha River at Darien, Ga., seems to indicate that the King Rail is largely associated with the "white marsh" zone of these coastal rivers. It should be emphasized, however, that many secondary plant communities occur within this zone with varying King Rail population densities depending upon local ecological conditions. 


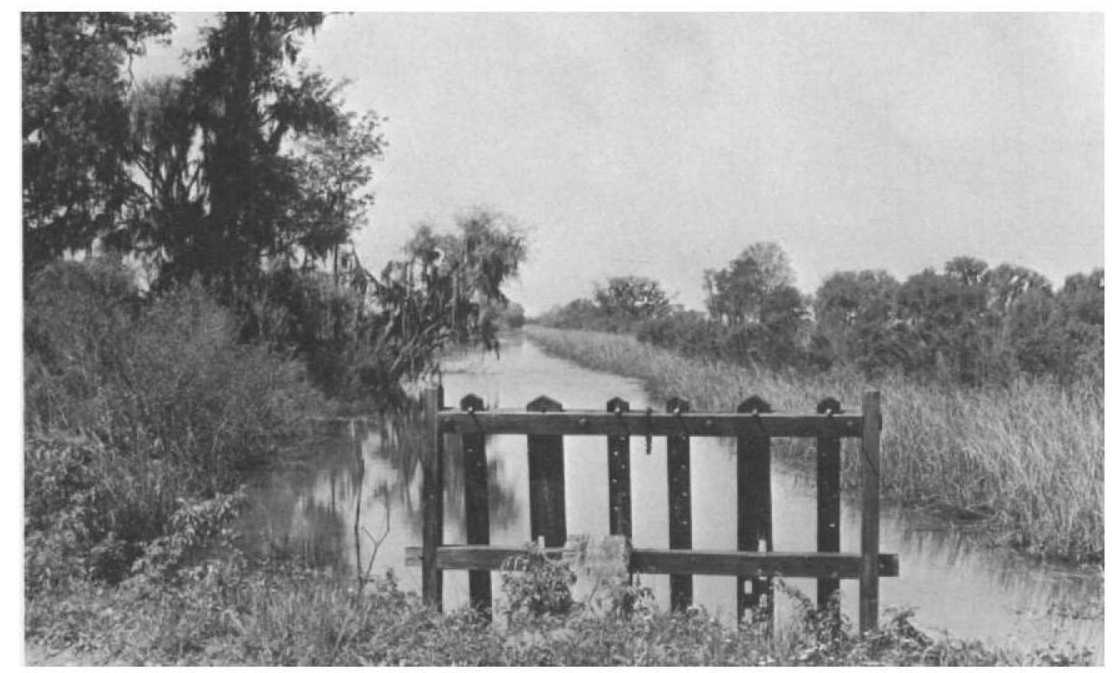

Froure 12.-Floodgate and ricefield canal near Savannah, Ga., April 1960. The land is irrigated as the tide rises from the Savannah River. King Rails nest in giant cutgrass (Zizaniopsis miliacea) seen along right-hand edge of canal. The high population density in this area is probably due to good nesting cover and the abundance of the red-jointed flddler crab (Uca minax), a favorite food of the rail.

In the Low Country, March and April appear to be the best months for censusing, as King Rails are more vociferous at this time than during any other period of the year. A narrow strip of marshland bordering a river is the most suitable place for censusing.

The marshland on the west side of the Pee Dee River and one of its tributaries, the Black River, for a distance of 8 miles north of Georgetown, S.C., totalling 3,000 acres, was selected as a sampling area. The sampling design was suggested by Dr. Don W. Hayne of the Institute of Statistics, North Carolina State College, Raleigh, N.C.

Georgetown is approximately 8 miles inland from the coast on Winyah Bay at the confluence of the Pee Dee and Waccamaw Rivers. The Black River flows into the Pee Dee about $21 / 2$ miles north of Georgetown. The mean tidal range at Georgetown is $31 / 2$ feet. At Georgetown the river is slightly brackish, and big cordgrass (Spartina cynosuroides) is an important plant component of the marsh, especially along old ricefield canals. Six 10-acre plots were composed mainly of the following plants: big cordgrass, 35 percent; Olney's three-square, 20 percent; cattail, 14 percent; giant cutgrass, 13 percent; arrow-arum (Peltandra virginica), 11 percent; softstem bulrush, 5 percent; and river bulrush (Scirpus fuviatilis), 2 percent.

Vegetation analyses were made also of three 10 -acre plots 8 miles north of Georgetown on the Black River. On the Black River, 
giant cutgrass formed 52 percent of the marsh vegetation, arrowarum 36 percent, and cattail 12 percent.

For the actual census, the entire marsh area, as shown on U.S. Geological Survey maps, was blocked off into 64 primary sampling units, each a 630 -foot-wide transect extending from the edge of the river to the land. Each transect was divided into 10-acre plots, the number in a transect depending upon the width of the marsh at that location along the river.

Ten of the 64 transects were randomly selected as primary sampling units, and one 10-acre plot from each was chosen for censusing. At least 1 hour between 5 and 8 a.m. or 5 and 7 p.m. during the period April 10 through 12, 1961, was spent in each plot counting calls.

The number of male King Rails in a transect was estimated by multiplying the number of 10 -acre plots in that transect by the number of birds heard in the census plot. The estimated total of 755 males in the 3,000 -acre marsh was derived by multiplying the average number of birds per sample transect by the total number of transects. The density estimate of 25.2 male birds per 100 acres was calculated by dividing the total population by 30 (the number of 100 -acre units in the 3,000-acre marsh). Since some of the calling King Rails were undoubtedly already mated, and most of the others would be eventually, the average number of breeding rails per 100 acres could be inferred to be 25 pairs (table 3 ).

Sampling indicated that the density of the King Rail population was higher at Georgetown in the Pee Dee River marshes than several miles up river along its tributary, the Black River. One 10-acre plot at Georgetown had six calling rails, and four other plots had four each. None of the Black River plots had more than two rails. The higher density at Georgetown could be attributed to the higher proportion of red-jointed fiddler crabs (Uea minax).

\section{Savannah National Wildlife Refuge}

The Savannah National Wildlife Refuge in South Carolina and Georgia, near Savannah, is about 25 miles upriver from the ocean on what was formerly a rice plantation (fig. 13) and is divided by the Savannah River. The larger acreage is on the South Carolina side. Its marsh is the fresh tidal type, with a tide which rises about 1 foot.

Giant cutgrass is the dominant vegetation of much of the marsh on the refuge. The old growth of cutgrass forms a nearly pure stand, and has an average height of about 5 feet, but will average higher when the new growth matures. Arrow-arum, dotted smartweed, and swamp smartweed (Polygonum hydropiperoides) are scattered about the marsh, particularly along the edges and on high spots. There are numerous small holes made by the red-jointed fiddler crab, an important food of the King Rail, along the tidal creeks and edges of the marsh. While making a survey of King Rail populations in April 


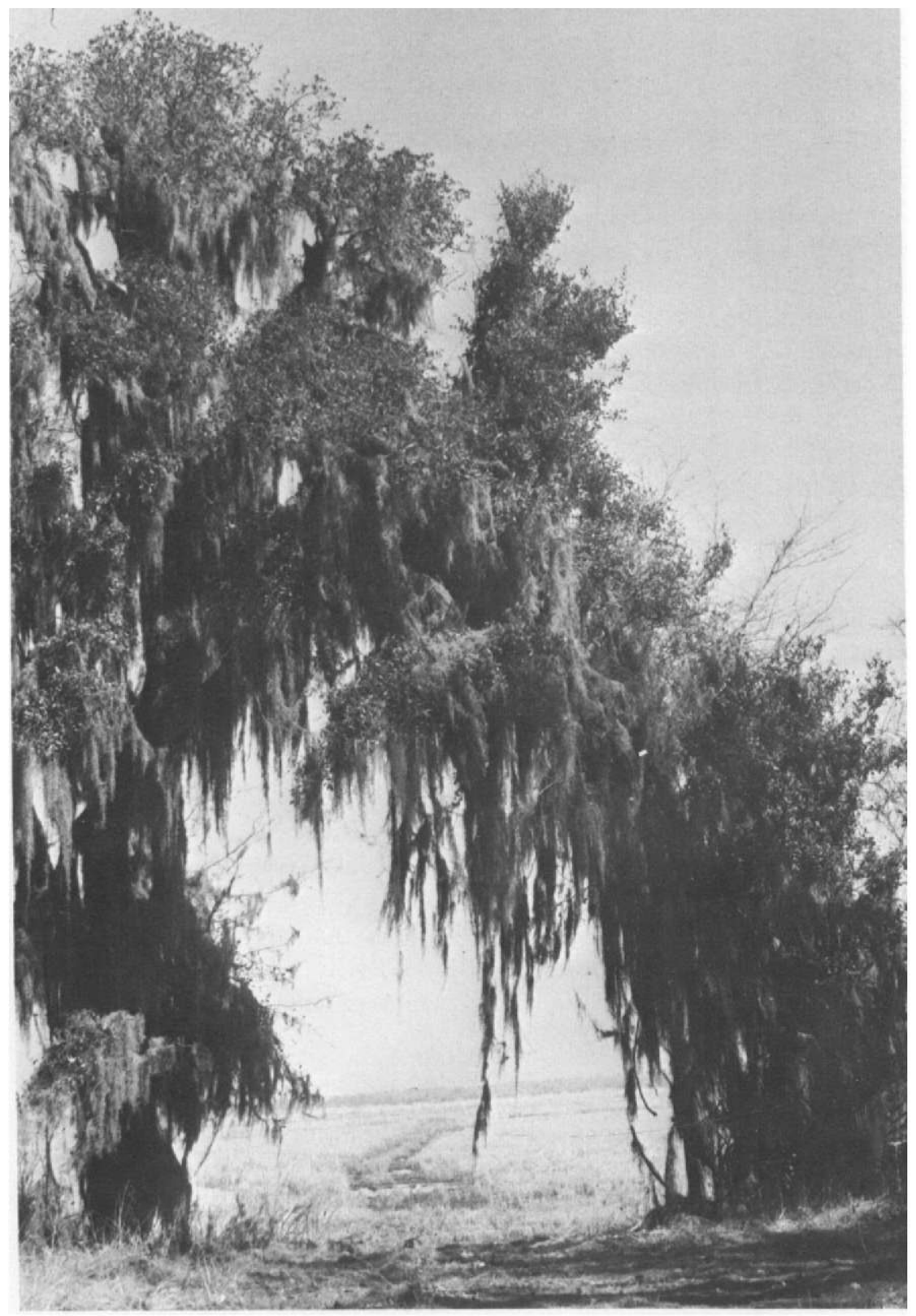

Fraurs 13.- South Carolina Low Country: ricefield nesting habitat in Jasper Oounty along the Savannah River, fall 1958. 
1960, I estimated a density of one pair per acre in the cutgrass marsh bordering the river. A year later I also heard many King, Virginia, and Sora Rails calling at night in the same marsh.

Much of the refuge canal system and some of the ponds are choked with alligatorweed, a plant that forms extensive mats upon which rails, gallinules, coots, herons, and several species of ducks do much of their foraging for aquatic insects (fig. 14). Small patches of giant

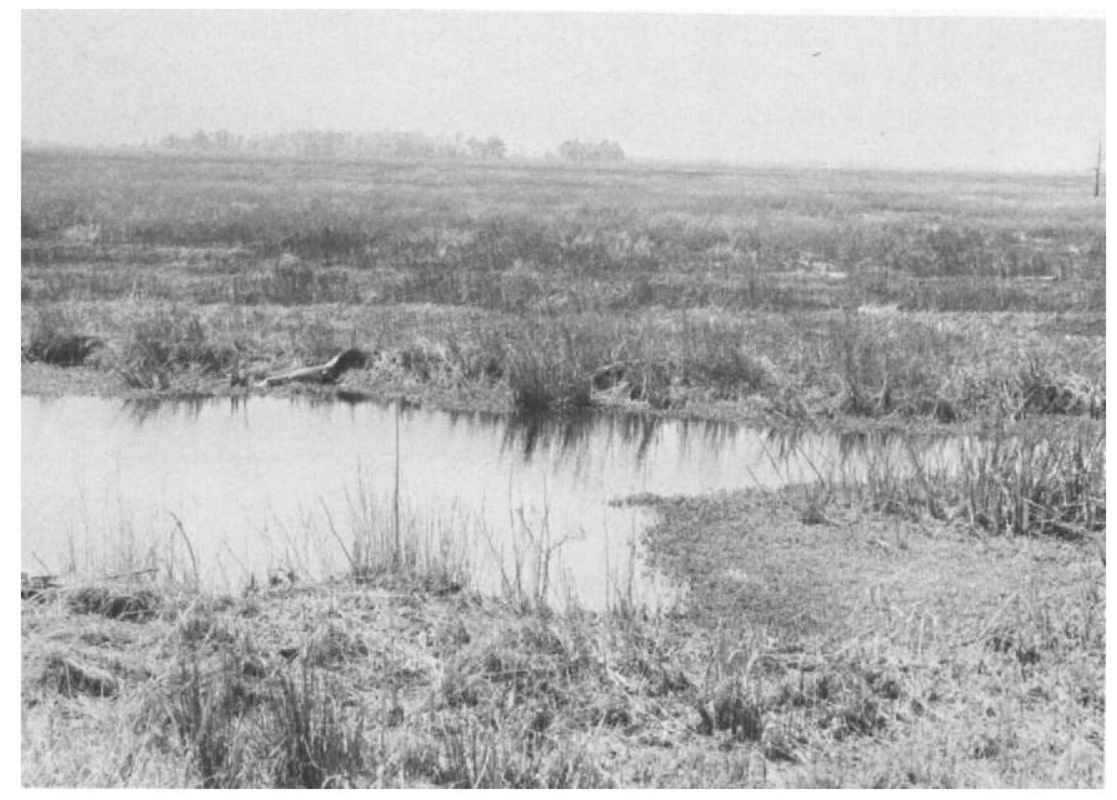

Fraune 14.-Allgatorweed (Alternanthera philoxeroides) in canal at Savannah National Wildlife Refuge, Jasper County, S.C., April 1960. This plant forms spongy, extensive mats upon which rails, gallinules, coots, herons, and ducks forage for aquatic insects, flsh, amphibians, and crustaceans. Such mats have an obvious value to birds that utllize its growth form to facllitate their quest for food. Note alligator on far side of canal. Alligators feed on many forms of animal life including various water-birds such as ralls.

cutgrass in which Purple Gallinules nest are sparsely distributed along the canals. I located many King Rail pairs with feeding territories along sections of the canals. Some of these territories were not more than 20 feet square, indicating the high food productivity of these aquatic mats. All of the King Rails that I observed feeding in the choked-up canals, however, nested on the other side of the dike in a deep-water impounded marsh containing a mixture of giant cutgrass, sawgrass, cattail, royal fern (Osmunda regalis), buttonbush (Cephalanthus occidentalis), and myrtle (Myrica cerifera).

I made a roadside count of calling males on April 12, 1960, along a 7 -mile route beginning at the north entrance to the refuge on U.S. 
Highway 17, continuing along the east dike, through the string of island hammocks, and ending at the Savannah River just inside the south entrance on U.S. Highway 17 . On this census, made between 6 and 7 p.m., 46 males were tallied (table 3 ).

On April 20, 1961, I estimated the breeding King Rail population in a nearly pure softstem bulrush (Scirpus validas) marsh along U.S. Highway 17 A, about 2 miles north of Savannah, Ga. The bulrush averaged about 5 feet in height, and the marsh had a firm bottom covered with 1 to 2 inches of water. A 13-acre section was marked off into transects, and King Rail territories were then spot-mapped on the basis of three calls from any one area. This mating-call count indicated a breeding population of 14 males in the 13-acre tract (table 3).

\section{Upper Savannah River Valley}

King Rails also nest further upriver in the Savannah River Valley section of the Upper Coastal Plain in South Carolina. Norris (1963, p. 2,19$)$ described the typical nesting habitat as a "Carolina bay"an oval-shaped water-filled depression with rank growths of maidencane and other aquatic plants.

\section{CHESAPEAKE BAY COUNTRY}

\section{Tidewater Virginia}

Tidewater Virginia is the section of the Middle Atlantic Coastal Plain that extends from the fall line (the line separating the Piedmont Plateau from the Coastal Plain) to the Chesapeake Bay. It is dissected by numerous rivers, the largest of which are the Potomac, the Rappahannock, the York, and the James.

The King Rail is common throughout the year in much of Tidewater Virginia and usually occurs in greatest numbers in marshes where big cordgrass is dominant. Big cordgrass is one of the best cover plants for King Rails in Tidewater because of its height and occurrence in fairly dense stands, and because it retains its life form throughout most of the year (fig. 15). In the early 1960's, I found King Rails common in the big cordgrass marshes at Norfolk, West Point, and Tappahannock.

Other marsh types, especially Olney's three-square, wild rice (Zizania aquatica), and cattail, are important for the King Rail, but there is less acreage of these types, and wild rice does not provide cover in the winter. During the winters of 1958 and 1961, I encountered several muskrat trappers who were inadvertently catching King Rails in the extensive Rappahannock River brackish marsh flats across the river from Tappahannock. These flats are dominated by Olney's three-square (fig. 16). Several King Rails were removed from muskrat 


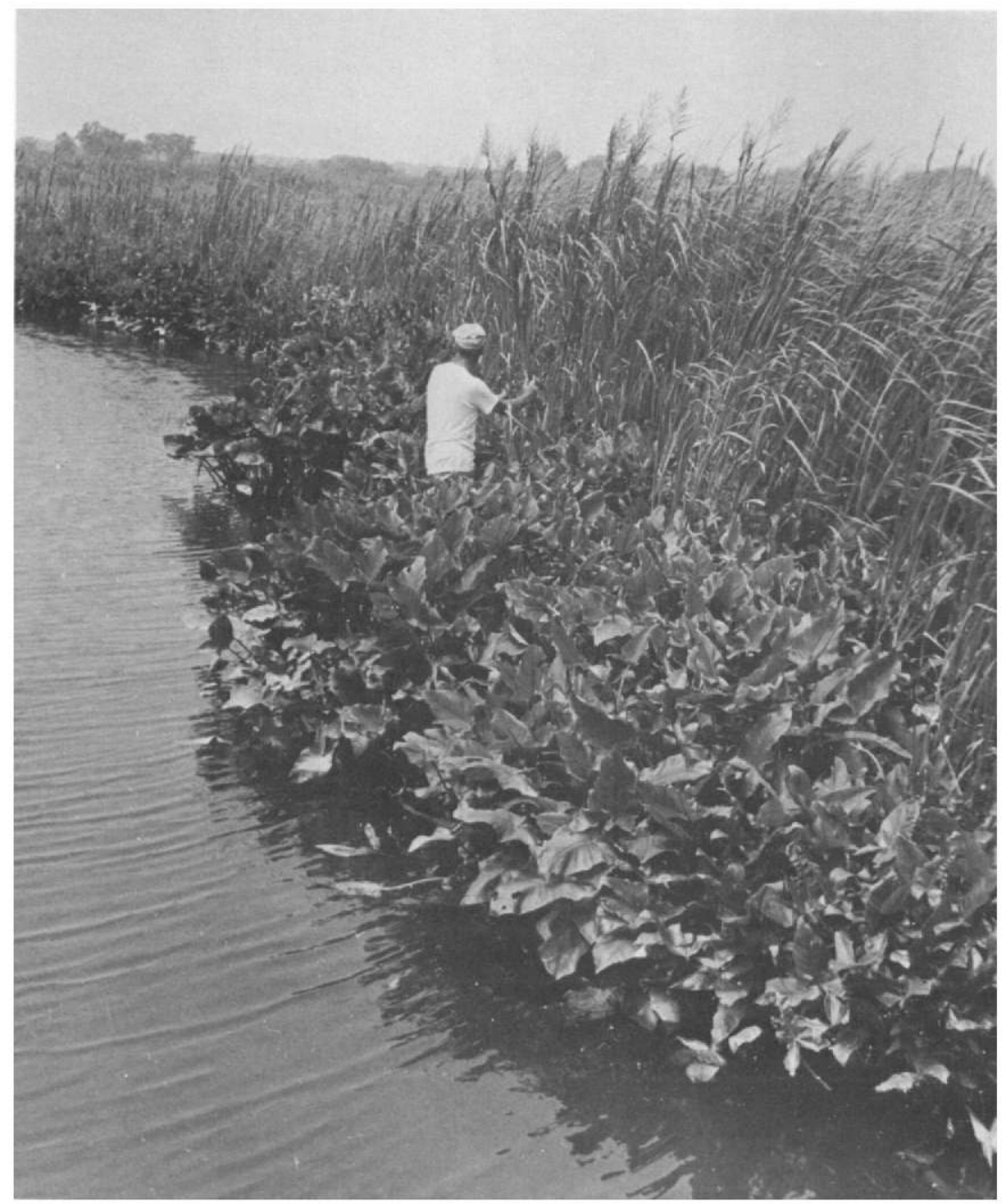

FIqURe 15.-Big cordgrass (Spartina cynosuroides) (tall plant) and arrowarum (Peltandra virginica) (broad-leaved plant next to water) along tidal creek, Nanticoke River marsh, Wicomico County, Ma., August 1967. Big cordgrass usually grows along the margins of tidal guts in brackish bay marshes, but may form extensive, nearly pure stands in brackish tidal-river mashes. It is one of the most important cover types for King Rails in the Chesapeake Bay region. (Photograph by Luther Goldman.) 


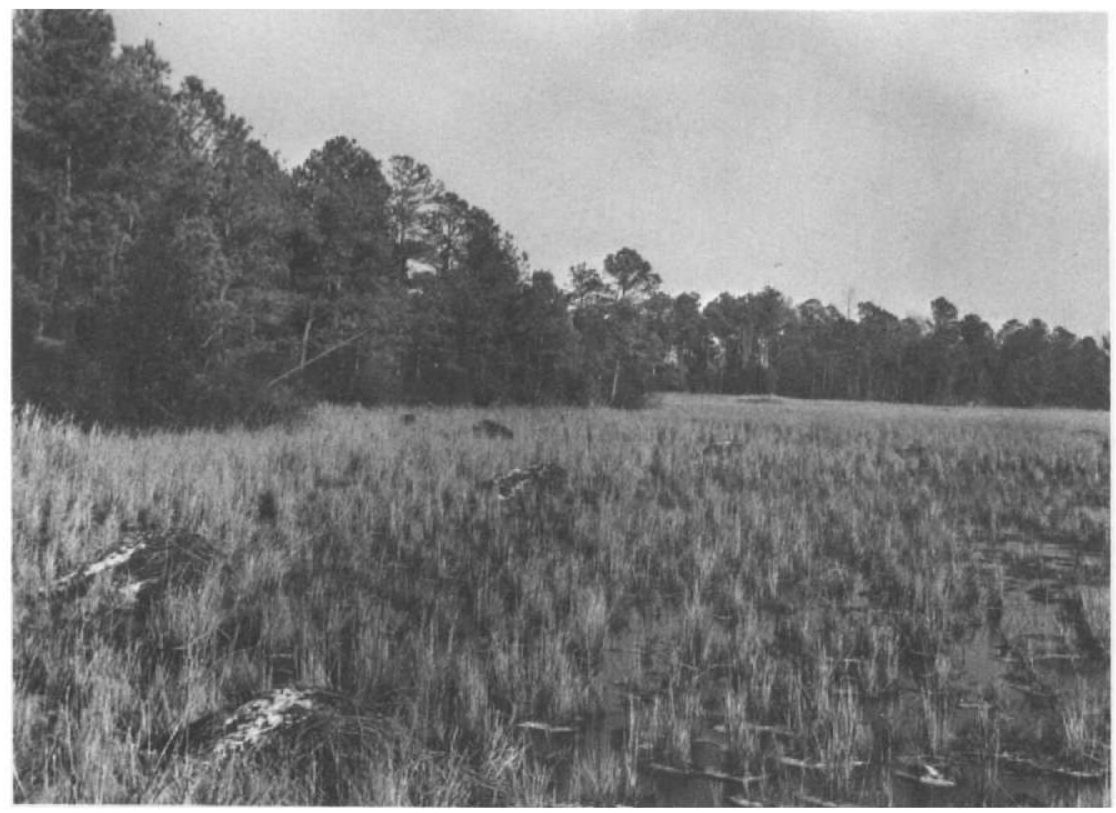

Froukz 16. -Winter abode of King Rail. Rappahannock River near Tappahannock, Va., January 1961. Vegetation is mainly Olney's three-square (Bcirpus olnewi) and saltmarsh cordgrass (Bpartina alternifiora).

traps as I watched a trapper run his line. In these and other tidemarsh habitats, tidal action along the creeks and over adjacent marshlands keeps the water open throughout much of the winter.

At Hog Island, Surry County, in the James River opposite historic Jamestown, C. C. Steirly found both King and Clapper Rails breeding. Steirly $(1959$, p. $47-48)$ made the following comments about the rail habitat on the island:

Apparently there is a salinity gradient between the east side of the refuge and the west side of Cobham Bay. Hog Point might be the dividing line. There seems to be a slight difference in the tidal vegetation between the two eides of the refuge although the cord grass marsh seems to be the dominant feature along the east or down river side. The King Rail is most often seen on the west side; however, there is as yet no proof that it does not breed on the east side. In one of the particular haunts of the King Rail, pickerel weed (Pontederia cordata) and bulrush (Scripus robustus) occur in some abundance where there is less tidal fluctuation.

\section{Virginia Eastern Shore}

The Eastern Shore peninsula of Virginia lies between Chesapeake Bay and the Atlantic Ocean. While King Rails would be expected to occur on the bay side of the peninsula, their presence on the offshore barrier islands on the ocean side would seem rather surprising; nevertheless, on these salty coastal islands King Rails are found in 
land-locked fresh-water marshes. Montagna and Wimsatt (1942, p. 434 436) collected a female on Rogue Island 11 miles off the coast between Hog and Cobb Islands. The specimen had a fully developed swollen brood patch, and its oviduct contained an egg with shell.

There are several records from Chincoteague Island. Robert E. Stewart encountered paired adult King and Clapper Rails with a brood in a salt meadow cordgrass marsh on this coastal island. The Chincoteague salt marshes are one of the important Clapper Rail hunting grounds along the Atlantic Coast, and King Rails occasionally turn up in hunters' bags.

One of the best King Rail areas on the bay side of the eastern shore peninsula is Bullbegger Creek, a tributary of the Pocomoke River. Big cordgrass is the dominant plant in this creek marsh.

At Knott's Island, at the head of Currituck Sound, partly in Virginia and partly in North Carolina, A. J. Duvall $(1937$, p. 462) and party collected a female King Rail and five chicks along a roadway in a salt marsh on June 1, 1936.

\section{Maryland Eastern Shore}

In Maryland the King Rail is mainly associated with tidal marshes of the Chesapeake Bay system, and is found in greatest numbers in the extensive brackish tidal-river marshes of the Eastern Shore, especially in the vast area of fresh and brackish bay marshes of Dorchester County (see R. E. Stewart, 1962, for a description of Maryland Chesapeake Bay marsh communities). In this area, the following plants are usually present as pure stands or are found in some combination in areas where King Rails occur: big cordgrass, broad-leaf and narrowleaf cattail (Typha latifolia and T. angustifolia), Olney's threesquare, switchgrass (Panicum virgatum), softrush, and rosemallow (Hibiscus moscheutos).

The importance of big cordgrass in the Maryland section of the Chesapeake Bay is comparable to that in Tidewater Virginia.

In the brackish tidal-river marsh community of the Choptank River at Dover Bridge between Talbot and Caroline Counties, a muskrat trapper caught 50 King Rails in a single season (January 1 to March 15). Most of the birds were caught where big cordgrass was dominant but usually mixed with Olney's three-square and switchgrass. Because of the sparseness of winter marsh cover, King Rails often seek means of escape and places for hiding different from those used during the rest of the year. A muskrat trapper on the Choptank River in Maryland reports that whenever he surprises a rail along a tidal gut in the marsh it almost invariably darts into a muskrat hole along an embankment.

Robert E. Stewart has observed both King and Clapper Rails in the same big cordgrass marsh along Ape Hole Creek in Somerset County. 
Both species are common there, probably because of the abundance of such prime rail foods as blue crabs (Callinectes sapidus), mud crabs (Sesarma reticulatum), red-jointed fiddler crabs, periwinkle snails (Littorina irrorata), and salt-marsh snails (Malampus lineatus).

In a brackish bay marsh community at Elliott Island, Dorchester County, on May 28, 1959, I heard King Rails calling between 11 p.m. and midnight. Most were calling from the narrow band of big cordgrass that characteristically borders the sides of Pokata Creek. Soras, Virginias, and Black Rails (Laterallus jamaicensis) were heard at the same time and in the same general area, but mostly in a saltmeadow marsh type community.

In a fresh bay marsh community north of Savannah Lake, Elliott Island, King Rails occur where the switchgrass marsh extends inland for a mile or so forming an understory beneath a loblolly pine (Pinus taeda) forest (fig. 17). It seems rather strange to flush a King Rail

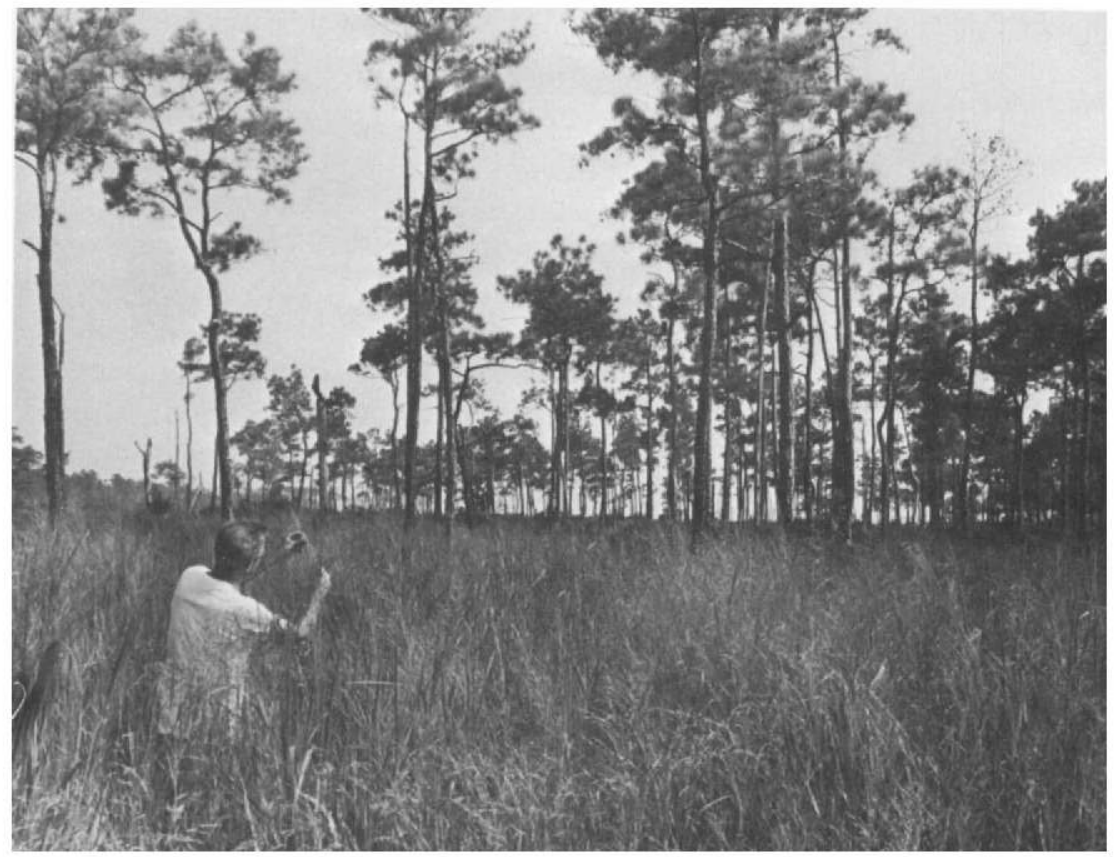

Froune 17.-Habitat of King Rail in loblolly pine (Pinus taeda) and switchgrass (Panicum virgatum) association, Elliott Island, Dorchester County, Md., August 1967. (Photograph by Luther Goldman.)

from beneath a stand of loblolly pine. The Short-billed Marsh Wren was found nesting and wintering in this same pine-switchgrass association. Switehgrass, which attains a height of 5 feet, retains its life form throughout the year, thus affording excellent cover, especially in winter when several other marsh plants have deteriorated. 
On June 10, 1965, I made a King Rail survey of a section of the Nanticoke River marshes, Wicomico County, across the river from the town of Vienna. This was a typical muskrat marsh in which Olney's three-square was dominant, with rosemallow scattered throughout. Four King Rail nests, located at the bases of rosemallow plants, were found in a 20 -acre section of the marsh. The life form of this plant, with its cradle-like base and broad leaves forming a protective cover above, makes it well suited for nest cover (fig. 18).

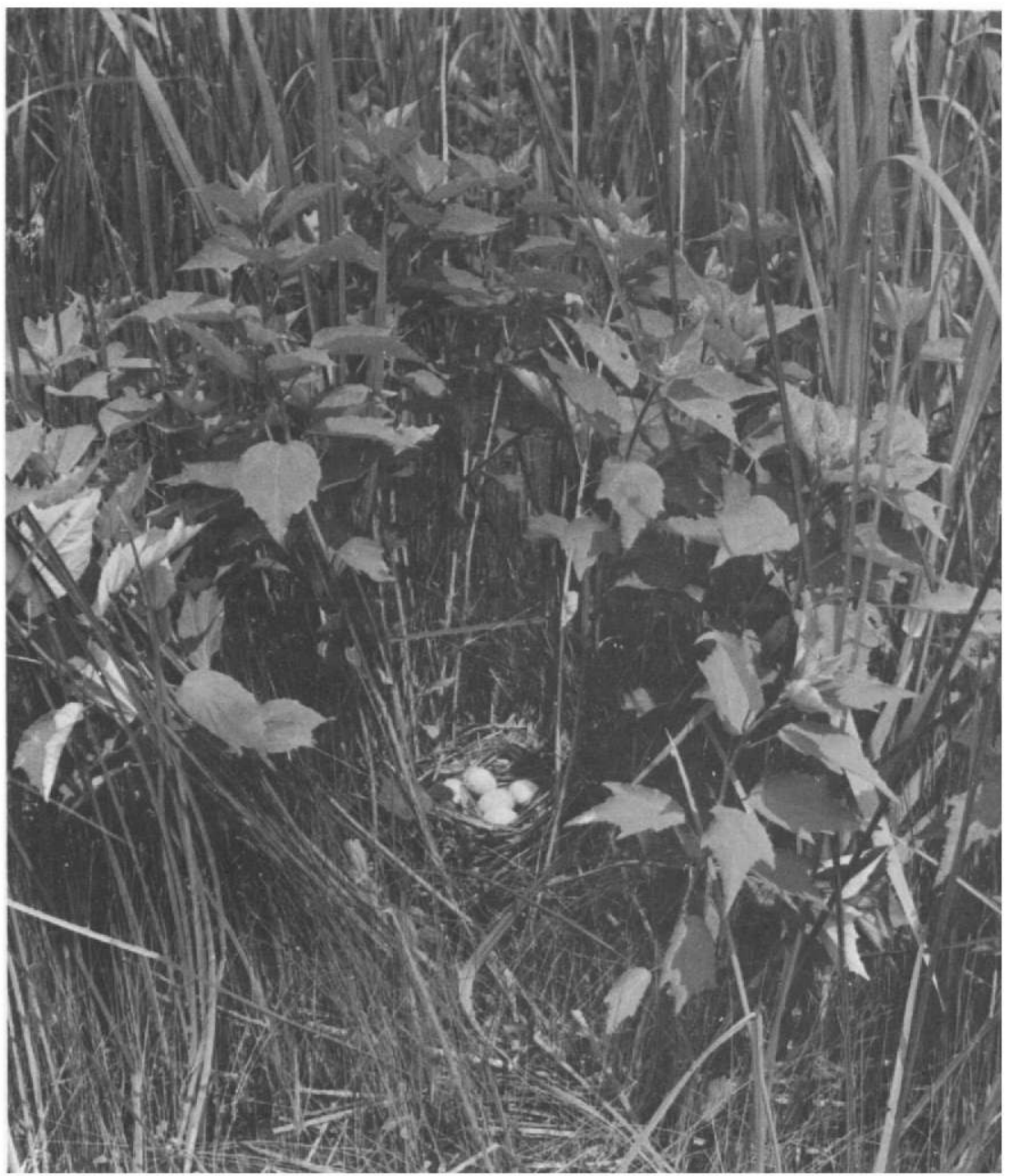

Frgure 18.-Nest and eggs of King Rail in Nanticoke River marsh, Vlenna, Wicomico County, Md., June 10, 1965. Nest found in section of marsh dominated by Olney's three-square (Soirpus olneyi) interspersed with rose mallow (Hibiscus moscheutos). Four nests found in this marsh were all in rose mallow. Because of the life form of this plant, the rail does not have to build a canopy over its nest as it does when using other plants. 
In May 1959, while censusing Red-winged Blackbirds on a number of small islands in Chesapeake Bay, I was surprised to find King Rails on almost all of them. The islands provide a brackish environment. On Long Marsh Island, May 26, 1959, I observed a nest constructed mostly of saltmeadow cordgrass and containing nine eggs (fig. 19).

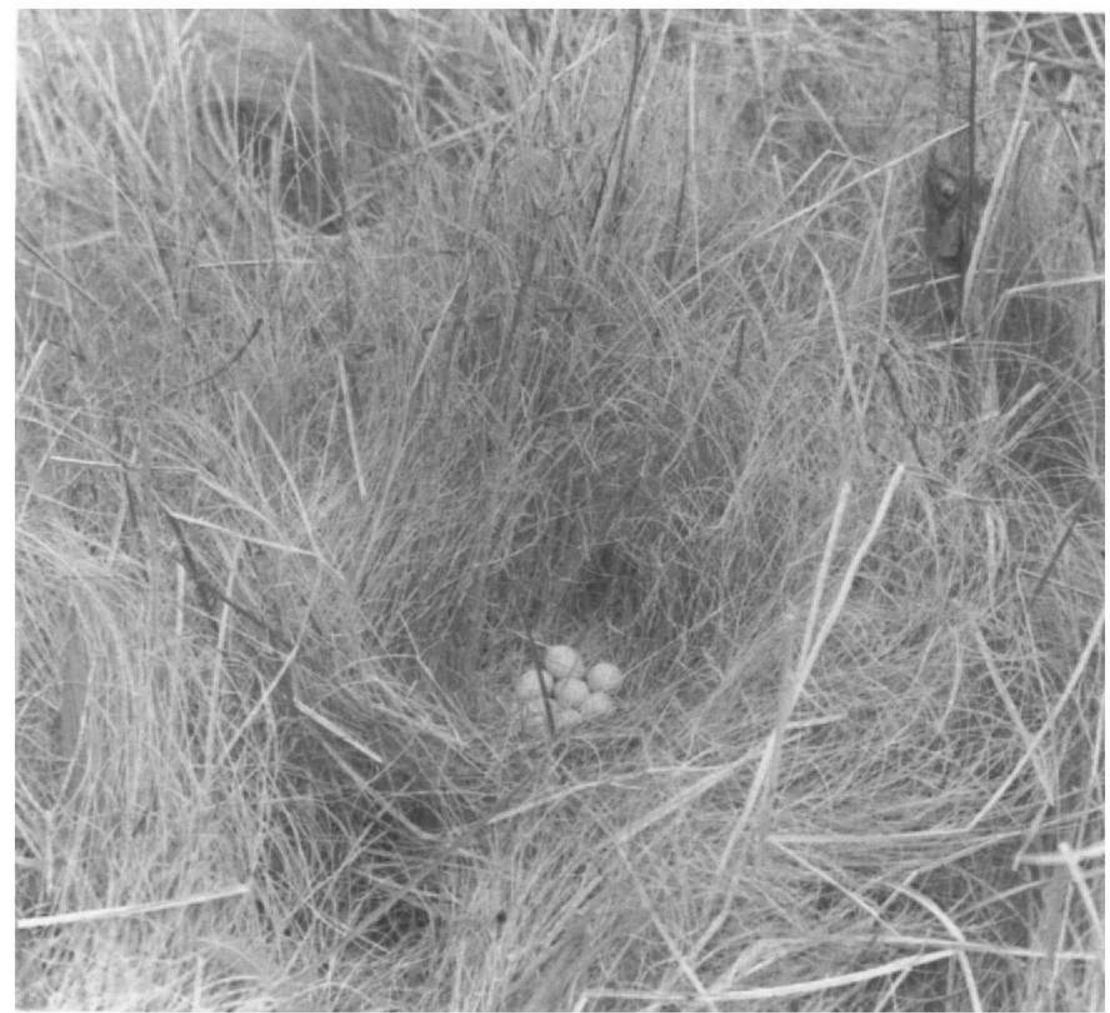

Frevre 19.-Nest and nine eggs of King Rail in brackish marsh, Long Marsh Island, Bastern Bay (of Chesapeake Bay), Queen Annes County, Md., May 26, 1959. Nest constructed of saltmeadow cordgrass (Spartina patens) and Olney's three-square (Scirpus olneyi).

Small patches of saltmeadow cordgrass were scattered throughout the dense growth of hightide-bush (Iva frutescens) on the island. The King Rail nest was only 15 feet from a Black Duck (Anas mubripes) nest. On another Chesapeake Bay island (Miller's Island) a King nest was found in a pure stand of saltmarsh cordgrass.

\section{Inner Coastal Plain of Maryland}

Four pairs of King Rails nested in 10 acres of shrub swamp-marsh mixture at the Patuxent Wildlife Research Center, near Laurel, Md., 
during May and June 1965. Softrush, tussock sedge (Carex stricta), and arrowhead (Sagittaria sp.) were the common emergent herbaceous plants. Woody marsh plants included swamp viburnum (Viburnum nudum), arrow-wood ( $V$. dentatum), buttonbush, alder (Alnus serru$l a t a)$, winterberry (Ilex verticillata), red maple (Acer mubrum), and willow (Salix nigra). In late summer Woodcock (Philohela minor) were common in this same area.

\section{DELAWARE BAY, DEL.}

King and Clapper Rails inhabit the extensive brackish bay marshes known as Broadway Meadows between Fleming's Landing and Woodland Beach, Kent County, Del. Two King-Clapper pairs and their nests were found in June 1960 at Taylor's Gut approximately halfway between Fleming's Landing and Woodland Beach (fig. 20).

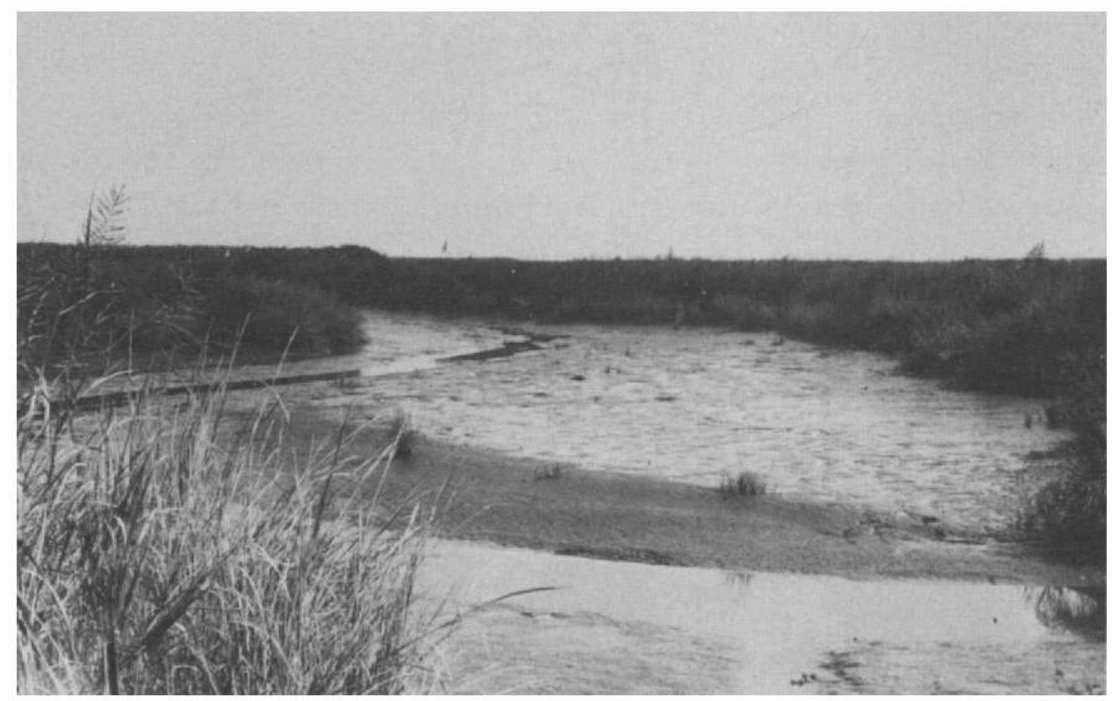

Fiaure 20.-Taylor's Gut at low tide, Kent County, Del., September 30, 1963. Vegetation in this breeding habitat of mixed King and Clapper Rafl populations is mainly saltmarsh cordgrass (Spartina alternifora), big cordgrass (Spartina cynosuroides), saltmarsh bulrush (Scirpus robustus), and hightide-bush (Iva frutescens). (Photograph by Frederick C. Schmid.)

The section of marsh at Taylor's Gut where mixed populations occur is more typical of Clapper Rail than of King Rail habitat. The domi- 
nant vegetation types are saltmarsh cordgrass and saltmarsh bulrush (table 4). Hightide-bush borders the tidal guts.

TABLE 4.-Plant composition at three stations in Broadway Meadows, Del., in 1960

[In percent, based on estimates for flve 10-foot-square quadrats at each station; tr. $=$ trace]

\begin{tabular}{|c|c|c|c|}
\hline & $\begin{array}{c}\text { Fleming's } \\
\text { Landing } \\
\text { (King Rails } \\
\text { only) }\end{array}$ & $\begin{array}{c}\text { Taylor's Gut } \\
\text { (Intermediste } \\
\text { area; King } \\
\text { and Clapper } \\
\text { Rails) }\end{array}$ & $\begin{array}{l}\text { Woodland } \\
\text { Beach } \\
\text { Causeway } \\
\text { (Clapper } \\
\text { Rails only) }\end{array}$ \\
\hline $\begin{array}{l}\text { Saltmeadow cordgrass. } \\
\text { Baltmarsh cordgrass. }\end{array}$ & $\begin{array}{l}50 \\
15\end{array}$ & $\operatorname{tr}$ & 70 \\
\hline $\begin{array}{l}\text { Boltmarsh bulrush } \\
\text { Big cordgrass } \\
\text { Olngy's throg }\end{array}$ & 25 & $\begin{array}{l}30 \\
10\end{array}$ & $\begin{array}{l}20 \\
10\end{array}$ \\
\hline Hightide-bush & & 10 & (n) \\
\hline $\begin{array}{l}\text { Bailtgrass } \\
\text { Groundsel-bush.......... }\end{array}$ & $\begin{array}{l}\text { tr. } \\
\text { tr. }\end{array}$ & & (n) \\
\hline
\end{tabular}

Two miles inland at Fleming's Landing only King Rails were observed. The vegetation at Fleming's Landing is composed mostly of saltmeadow cordgrass and saltgrass (Distichlis spicata). Occasional patches of Olney's three-square, big cordgrass, and saltmarsh cordgrass were distributed through the saltmeadow marsh, and as in the intermediate area at Taylor's Gut, hightide-bush bordered some of the tidal guts.

Two miles further toward Delaware Bay along the Woodland Beach Causeway, Clapper Rails were abundant, but King Rails were not observed. Saltmarsh cordgrass and saltmarsh bulrush were the dominant plants at this station. Hightide-bush was not present.

It is interesting to note that in the Taylor's Gut area salinity readings are intermediate between those at the other stations (table 5).

TABLE 5.-Salinity determinations at three stations in Broadway Meadows, Del. in 1960

[In parts per million. Water samples were analyzed in the chemistry laboratory, Patuxent Wildiffe Research Center, Laurel, Md.; ses strength is 32,000 to 35,000 p.p.m.]

\begin{tabular}{|c|c|c|c|}
\hline & $\begin{array}{l}\text { Fleming's } \\
\text { Landing }\end{array}$ & $\begin{array}{l}\text { Taylor's } \\
\text { Gut }\end{array}$ & $\begin{array}{l}\text { Woodland } \\
\text { Besch } \\
\text { Causeway }\end{array}$ \\
\hline 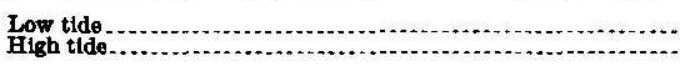 & $\begin{array}{l}4,380 \\
3,700\end{array}$ & $\begin{array}{l}7,190 \\
5,670\end{array}$ & 7,600 \\
\hline
\end{tabular}

The red-jointed fiddler crab was abundant at Taylor's Gut during the period 1959 through 1963, and formed the main food of the rails. There was a marked diminution in the fiddler crab population in 1964, and a corresponding decrease in the rail population.

Other breeding birds at Taylor's Gut in order of relative abundance are the Long-billed Marsh Wren, Red-winged Blackbird, Song Sparrow (Melospiza melodia), Seaside Sparrow (Ammospiza maritima), 
Swamp Sparrow (Melospiza georgiana), Black Duck, and Least Bittern. The muskrat, raccoon (Procyon lotor), and rice rat (Oryzomys palustris) are common mammals in the area.

\section{GREAT LAKES REGION}

In Lake County, Ill., Beecher (1942, p. 13-14) found the Carex lacustris consocies or lake sedge-marsh wren community to be the optimum breeding habitat of the King Rail. Three nests were located in 5.39 acres (Beecher, 1942, p. 29). Beecher characterizes this marsh type as follows:

Although the Typha consocies is so distinctive in its characteristics, there is considerable overflow of the species presumably finding their optimum within it bounds into the lake sedge which usually adjoins it in shallower water. Cares lacustris tends to exist as a closed community; it is more completely dominant in its own zone and its boundaries more sharply marked out than those of any other plant in the hydrosere. To state that it has the same lifeform as Typha means nothing, since, though much coarser than the grass-like sedges which follow it, the stalk offers little suppont. Nests of bittern, gallinule and blackbird are decidedly less frequent than in cattails, those of the redwing being constructed on a stool, generally. But the King and Sora Rails and the Prairie Marsh Wren are much more abundant in this sedge than in cattails, suggesting that it has qualities of its own. Primarily, it offers the tussock or stool type of substrate so attractive to rails, and anyone viewing this community for the first time would appreciate its fitness for the wrens. The growth is denser, less erect and, doubtless, easier to work.

The King Rail also formerly occurred commonly in the extensive cattail marshes of the southwestern shore of Lake Erie. On May 30, 1931, Milton Trautman (personal communication) recorded $18 \mathrm{King}$ Rails in 1 hour in these marshes. Trautman further stated that in the Sandusky Bay region, on many June and July evenings during the years between 1925 and 1934, he saw from one to eight broods on roads adjacent to marshes. At Buckeye Lake in east-central Ohio, Trautman (1940, p. 229-230) reported more than 50 pairs nesting annually between 1922 and 1930 . Trautman told me that by 1959 only two or three pairs nested there. Surveys in 1961 by Trautman and others to determine the status of the King Rail in Ohio revealed that it was disappearing at an alarming rate.

In Ontario, Baillie (1940, p. 109) reported five breeding localities (based on the presence of nests or broods) along the southern edge of Ontario from Lake St. Clair to Toronto: St. Anne's Island, Lake St. Clair, Lambton County, May 1882 (nest of 13 eggs) ; eastern end of the north shore of Lake Erie, at Point Abino, Welland County, May 30, 1894 (nest of 10 eggs) ; north shore of Lake Erie, at Long Point, Norfolk County, summer of 1921 and 1926 (young); western end of the north shore of Lake Ontario at Toronto, August 22, 1938 (young); and at Hamilton, August 6, 1939 (young). 


\section{NORTH-GENTRAL PRAIRIE MARSHES}

Tanner and Hendrickson (1956, p. 54-56) studied the King Rail in the marshes of Dewey's Pasture Public Shooting Ground, Clay County, Iowa, from April 1951 to April 1953. Their description of the habitat in this area is as follows:

The 402-acre research area included 28 marshes lying in the hollows between gently sloping prairie knolls. These marshes ranged in depth from several inches to 4 feet and in area from 0.2 acres to 18.0 acres. Of the total 96.4 acres of marsh, 81.4 acres supported emergent vegetation habitable by rails. The remaining 15.0 acres consisted of open water. The predominant species of emergent vegetation in the shallowest water along the shores were blue-joint grass [Calamagrostis canadensis], prairie cordgrass [Spartina pectinata], tussock sedge and fox sedge [Cares vulpinoidea]. In waters of intermediate depth the most abundant species of emergent plants were river grass [Fluminea festucacea], lake sedge, sweet flag [Acorus calamus] and water smartweed [Polygonum coccineum]. In deeper waters the predominant specles were broad-leaved cattail, narrow-leaved cat-tail, river bulrush [Scirpus fluviatilis], hard-stemmed bulrush [Scirpus acutus], pale great bulrush [Scirpus heterochaetus] and large bur-reed [Sparganium eurycarpum]. The plant names follow Hayden (1943), .. . . . . . Four of the six nests were found in areas of marsh in which lake sedge was the predominant regetation, while the others were found in pure stands of river bulrush and were attached to plants of that species. Of the four nests located in the lake sedge cover-type, only one was actually attached to plants of that specles. The others were supported by tussocks of blue-joint grass or cordgrass, or clumps of hard-stemmed bulrush, which occurred here and there among the lake sedge.

The estimated number of breeding adults in the 81.4 acres of marsh was 12 . In the same area there was an estimated adult breeding population of 54 Virginia Rails and 52 Soras.

\section{NORTHERN GREAT PLAINS}

The King Rail rarely breeds in the northern Great Plains, but R. E. Stewart (personal communication) located a breeding pair in a prairie pothole in the Missouri Coteau of western Dickey County, N. Dak., in June 1961. This pothole was a fresh-water type and was composed chiefly of whitetop grass (Fluminea festucacea) and slough sedge (Carex atherodes), with an outer border of river bulrush. Several pairs of Virginia Rails and Soras were also observed in this same pothole. Stewart also recorded single King Rails on June 5 and 24, 1963, about 12 miles west of Buchanan, Stutsman County, N. Dak., where common cattail and common spikerush were the dominant plants. 


\section{Description}

\section{SIZE}

The male King Rail is generally larger and heavier than the female. Males in my study weighed about 100 grams more than females. Six of nine adult males weighed over 400 grams each, and the average of all nine was 415.4 grams, whereas the average of nine females was 306.0 grams. These weights do not differ greatly from those of Clapper Rails (table 6).

Measurements of body length and wing length also reflect the difference in size of the sexes. These are compared in table 7 along with measurements of the Clapper Rail, which is somewhat smaller in these dimensions.

\section{ADULT PLUMAGE}

There are no apparent differences between the plumages of the male and the female King Rail. Ridgway and Friedmann (1941, p. 83) described the plumage as follows:

Forehead, crown, occiput, and nape deep, rich mummy brown, the feathers of the forehead and crown with shiny black shafts; scapulars, interscapulars, upper and lower back, rump, upper tail coverts, and rectrices deep fuscous to fuscous-black, the feathers broadly edged with tawny-olive to buckthorn brown, the edges becoming broader on the more posterior parts, often occupying (between the two margins) more than half the width of the feather on the long scapulars and the feathers of the rump and the upper tail coverts, narrow on the anterlor interscapulars; upper wing coverts deep hazel to bright russet, some of the outer median and greater coverts with narrow whitish tips and a concealed narrow subterminal whitish band; remiges sepia, the outer web of the outermost primary often slightly paler-Saccardo's umber; a light strip from the base of the maxilla over and behind the eye light pinkish cinnamon; rest of lores, circumocular area, cheeks and auriculars grayish mummy brown; lower cheeks and sides of throat cinnamon; chin and middle of upper throat white; lower throat, breast, and upper abdomen cinnamon becoming paler in the mid-ventral part of the upper abdomen, the feathers faintly tipped with white on the upper abdomen, without pale tips on the breast feathers ; middle of abdomen light buff; thighs similiar but transversely barred with deep drab to hair brown; flanks sepia barred with white, the feathers tipped with white and crossed by two or three white bars each; vent similar to flanks; under tail coverts white, not buffy, and with sepia areas reduced making the white bars wider; the outer webs of the lateral ones wholly white; axillars and under wing coverts deep rich sepia tipped and crossed by narrow bars of white ; . . .

Ridgeway and Friedmann described the dark and light phase adult plumages of the King Rail, and suggested that the light phase rarely 
occurs. My recent investigations indicate that the so-called light phase plumage is probably the result of hybridization or intergradation in areas of mixed King and Clapper Rail populations, or it may be due simply to individual variation.

In my collection I have a series of $16 \mathrm{King}$ and Clapper Rail specimens taken from a 1-square-mile area of brackish marsh in Delaware (table 1). In this serjes there are Kings and Clappers with typical plumages and also gradations from one type to the other. Some of the specimens appear to be light phase King Rails. Ridgeway and Friedmann (1941) made no mention of locality, habitat, or the possibility of mixed populations where so-called light-phased birds were collected.

TABLE 6.-Weights of King and Clapper Rails

[In grams. All specimens were adults. Bottom line shows mean weights.]

\begin{tabular}{|c|c|c|c|c|c|c|c|}
\hline \multicolumn{2}{|c|}{$\underset{\text { (R.e. elepans)! }}{\text { King Rail }}$} & \multicolumn{2}{|c|}{$\begin{array}{l}\text { King Rafl } \\
\text { (R. e. tenuirostris) }\end{array}$} & \multicolumn{2}{|c|}{$\begin{array}{l}\text { Clapper Rsil } \\
\text { (R.l. crepitans) }\end{array}$} & \multicolumn{2}{|c|}{$\underset{\substack{\text { Clsper R. } \\
\text { Rall }}}{ }$} \\
\hline Males & Femsles & Males & Females & Males & Females & Males & Females \\
\hline $\begin{array}{r}339.9 \\
366.0 \\
367.9 \\
421.0 \\
427.0 \\
436.0 \\
498.3 \\
458.0 \\
490.0\end{array}$ & $\begin{array}{l}253.0 \\
272.0 \\
305.0 \\
313.3 \\
319.0 \\
320.0 \\
322.0 \\
323.0 \\
325.0\end{array}$ & $\begin{array}{l}271 \\
306 \\
317 \\
331\end{array}$ & $\begin{array}{l}220 \\
255 \\
268\end{array}$ & $\begin{array}{l}332.2 \\
335.0\end{array}$ & & $\begin{array}{l}300 \\
325 \\
300 \\
325 \\
300 \\
350 \\
300 \\
300 \\
325 \\
350 \\
350 \\
350 \\
325\end{array}$ & $\begin{array}{l}275 \\
275 \\
275 \\
278 \\
275 \\
275 \\
250\end{array}$ \\
\hline 415.5 & 308.9 & 306.3 & 247.7 & 333.6 & & 320.8 & 271.4 \\
\hline
\end{tabular}

1 From Arkansas, Delsware, and Louisiana (author's data).

3 All from Merico (Warner and Dickerman, 1939, p. 80).

Both from Delaware (author's data).

- All from Sonth Carolins, each to nearest 25 grams; race (R. l. crepitans or $R$. l. waynei) not specified (Blandin, 1963, p. 33).

\section{TABLE 7.-Measurements of King and Clapper Rails}

[From Ridgway and Frledmsnn, 1911. All spectmens were adults. All meagurements are given in mm. Wing measurements are for the chord, from bend of wing to tip of longest primary]

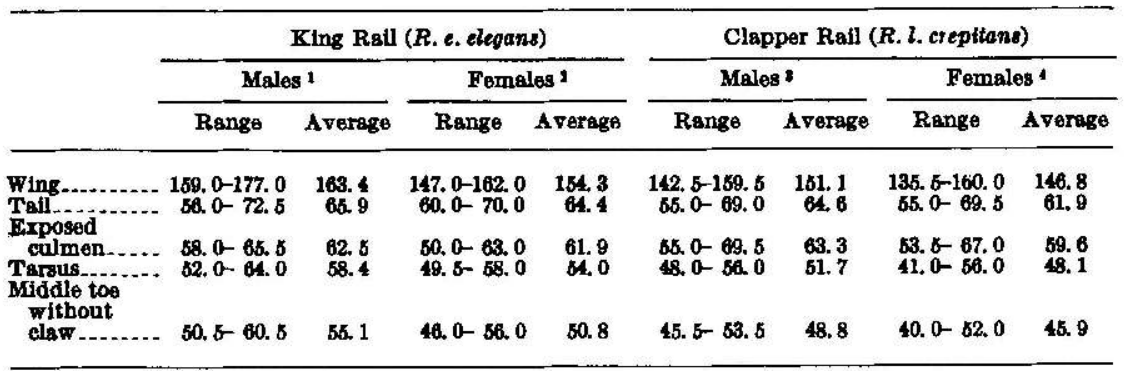

18 specimens from nlinols, Missourl, District of Columbia, Virginla, Alabams, Loulsiana, South Carolina, and Florids.

314 specimens from Illinols, District of Columbia, Maryland, Virginis, Louisisna, and Florida.

21 specimens from Massachusetts, New York, New Jersey, Virginia, and North Carolina.

117 specimens from New Jersey, VIrginia, and North Carolina.

Norr.-An incubating female (adult ?) King Rall collected at Stuttgart, Ark., May 1962, had a left wing messurement (chord) of only $141.0 \mathrm{~mm}$.; a paired female (adult ?) collected at Taylor's Cut, Kent County. Del., Apr. 15, 1968, had a left wing measurement (chord) of $145.0 \mathrm{~mm}$. 
The most unusual plumage that $I$ have seen was that of a very dark brown, almost blackish bird near Lake Okeechobee, Fla., January 1958. William B. Robertson (personal communication) told me of seeing several birds with similar dark plumage in the Everglades, and Luther C. Goldmarı collected such a specimen near Cape Sable, Fla. Dr. Harry C. Oberholser examined the specimen and remarked that it had a most unusual plumage. Apparently he did not make a critical study of it, and it has since been lost.

\section{LEGS AND FEET}

Legs and feet are pale brownish gray. An adult male collected at Welch, La., January 12, 1963, and two adult males collected in August. 1963 , in Delaware, had a pinkish-brown color on the inside and outside heel areas and immediately above. This heel color is apparently typical of birds in their second year or older.

\section{BILL}

In most adult birds the bill is orange-yellow from the base to at least the nares in the upper mandible, and usually slightly beyond in the lower mandible. The outer part of the bill is brownish. However, one marked wild bird known to be at least 2 years old had a lightishbrown bill more typical of immatures. A captive immature did not attain the color at the base of the bill until it was 10 months old. The color was then yollowish rather than orange-yellow. Young wild birds 2 to 3 months of age had lightish brown bills. The upper mandibles of these birds were darker.

\section{TONGUE AND LINING OF MOUTH}

Tongues and mouth linings of birds 1 year or older, examined immediately after collection, were a bright orange-red. Young birds in juvenal plumage, collected during the summer, had yellow tongues and mouth linings.

\section{EYE}

Irides of adult King Rails are reddish-orange while pupils are grayish-black. Eyes of newly hatched chicks are grayish-brown, and 1- and 2-month-old birds have dull-brown irides.

\section{NOTES ON SEXING AND AGING}

In a 50-bird sample from Louisiana, examined 3 months after collection in late fall, I was able to sex 47 of 50 birds by weight, and age 36 of 45 by color of the bill and heel. As an aging criterion, the color of the bill is used most accurately with live or freshly killed birds, because with time it fades. Wing measurements can also be used as an aid in sexing birds, since the average for males is nearly 10 milli- 
meters greated than that for females. From late summer to at least early winter, the presence of a bursa in young birds will distinguish them from adults.

\section{MOLTING}

Adult King Rails have a complete molt and are flightless for nearly a month. Young of the year undergo a partial molt which does not include the tail and flight feathers.

In the Middle Atlantic States the molting season for King Rails extends from the beginning of the breeding season in late May until the beginning of fall migration in early October.

In this study, breeding birds found in molt during May and June were replacing only body feathers. Molt of the remiges and rectrices was not observed until the first week in July. I have not been able to ascertain the relation between the partial molt during the breeding season and the complete molt in the summer. Birds that are renewing their body feathers while nesting in May and June may be undergoing prenuptial molts or early postnuptial molts during which the wing and tail feathers are not dropped.

Bent (1926, p. 262) stated that adult King Rails undergo a partial molt of the contour plumage during early spring. Eight specimens collected in the Middle Atlantic States in March and April showed no signs of molt. An adult female King Rail in the U.S. National Museum, taken at Alligator Bluff, Kissimmee River, Fla., April 9, 1901, was molting body feathers when collected. This could well have been a breeding bird because in Florida this species begins nesting in late winter. In my records the earliest recorded dates of molting by King Rails are May 28, 1960, and May 29, 1964, when an adult or subadult male and female, respectively, were found in breeding condition at Woodland Beach, Del. The male had pinfeathers on the underside of the neck, the sternal region, and the crural tract. Feather renewal on the female appeared to be about three-fourths complete and was proceeding simultaneously in most areas of the body. Three King Rails in breeding condition examined at Laurel, Md., June 12 and 18 and July 3,1965 , also were molting body feathers.

Molting rails in breeding condition have previously been reported. Watson (1962, p. 350 ) collected molting Spotted Rails (Pardirallus maculatus) in breeding condition in Cuba; Warner and Dickerman $(1959$, p. 50), working near Mexico City, reported two female King Rails (Rallus elegans tenuirostris) molting in May during the nesting season.

My earliest example of a King Rail molting its wing and tail feathers was at Laurel, Md., July 7, 1965. This bird was flightless. Two other birds trapped at Laurel, one on July 14, 1967, the other on July 24, 1967, also were flightless. A female collected near Woodland Beach, 
Del., July 30, 1964, had nearly completed molting. Its now remiges and rectrices were about half grown, and there was evidence of a late stage of feather replacement in all tracts except the head and upper neck regions.

A captive subadult female began molting wing and tail feathers by the latter half of July. Two of three adults collected in Delaware on August 23, 1963, had nearly completed their molts of wing and tail feathers; the third had no wing or tail feathers.

On August 3, 1967, I took two birds from the Nanticoke River marsh, Vienna, Md., that had not yet begun to molt.

The molting period for the Clapper Rail in the Middle Atlantic States is apparently the same as that for the King Rail. A pair of molting Clapper Rails in breeding condition was collected at Woodland Beach, June 29, 1964. Only the body feathers were being molted.

Robert E. Stewart (1952, p. 57) trapped and banded many Clapper Rails at Chincoteague, Va., and made the following notes on their molt:

During the trapping period [July 16-August 31] most of the adults were undergoing their post-nuptial molt . . . The individual molting period lasts about one month. The first adult observed in full molt was trapped on July 21. During the period August 24 to August 31 (period just before hunting season) a total of 11 adults were trapped. Of these only 5 had completed their molt and were capable of flight, while 4 were in heavy molt, and were completely flightless. Surprisingly enough the other two adults had not even started to molt and were in very worn plumage.

In a group of young captive King Rails, the postjuvenal molt was underway when they were 50 days old. Molting of the body feathers began before the young could fly, when the flight feathers were about one-half to three-fourths unsheathed. Another group of young King Rails, raised in captivity after being hatched on June 7, completed their postjuvenal molt by the end of the first week of September. 


\section{Breeding Biology}

Studies of the breeding biology of the King Rail were made mostly on the Grand Prairie in Arkansas and Prairie Counties, Ark., during the period 1951-55.

In late winter when rails return to the prairie from more southern latitudes or simply become conspicuous in areas where they have been present all winter, the most suitable habitat for the establishment of nesting territories is the narrow strip of marsh found in roadside ditches. At this season there is little suitable cover elsewhere. Old rice stubbles are sometimes used for nesting, but many of these are dried up or whipped down by winter winds and rains or are plowed under in the early spring.

\section{HOMING}

Some males or females return to the same territory in consecutive years. An incubating bird of undetermined sex banded on a nest at Stuttgart, Ark., May 6, 1952, was recaptured the following year on May 1, on a nest 30 feet from the previous year's nest site. An incubating bird of undetermined sex was banded on its nest at the Patuxent Wildlife Research Center, Laurel, Md., July 3, 1965, and recaptured in a trap with a mate and brood of eight young on July $8,1966,50$ feet from the 1965 banding site.

\section{TERRITORIES}

Territories occupied by King Rails in roadside ditches consist of small strips of fresh-water marsh. The dominant plants in most of these small marsh strips (in order of relative abundance and consequently of relative importance as nesting cover for King Rails in 1952) were soft-rush, awl-fruited sedge, bottlebrush sedge (Carex comosa), lake sedge, common spikerush, beakrush (Rhynchospora sp.), an undetermined Graminae, broad-leaved cattail, and smartweed (Polygonum sp.).

The schedule of arrival of males in the area and the stage of courtship determine size and choice of territory. It is conceivable that the earlier arrivals manage to claim larger and more suitable territories than those which arrive later when competition is keener. However, territorial boundaries are rather fluid during the earlier part of the courtship period. As additional males move into an area of suitable 
roadside ditch habitat, the large courtship-feeding territories of the first contingent tend to shrink.

Initial occupation of territories is indicated by the mating call. During the last week in February and the first week in March 1955, one male King Rail gave the mating call at various points along 975 linear feet of roadside ditch. By the second week in March its mating call was heard from about 500 feet of roadside ditch; its territory then was about half its original size. The diminishing of the territory was caused by : $(a)$ Pressure from another courting male, $(b)$ burning of cover along part of the ditch bank within the original calling territory, and $(c)$ relatively modest territorial requirements for nesting, particularly if there is plenty of water and ample aquatic animal life for food in the area about the nest.

Approximate sizes of nesting territories were determined by measuring the distances between three active nests in the same ditch; from the center nest it was 298 feet to the nest on one side and 166 feet to the nest on the other side. The ditch was about 30 feet wide at all three points.

\section{Defense of territories}

King Rails defend their territories both inter- and intra-specifically. When another King Rail invades a territory, the possessor often prepares to charge by coming to a "freeze," assuming a partial crouch, drawing in its neck, and slowly ruffling its feathers. It then chases the intruder on foot and on the wing.

As additional King Rails move into suitable nesting habitat, there is much fighting, particularly near boundaries of the more desirable territories. I observed a typical skirmish in a narrow ditch bordering a secondary road on April 21, 1955. At this unstable territorial boundary, two males attacked each other with bill and claws, sparring like fighting cocks for about 20 seconds. Then the battle suddenly ended, and the birds moved in opposite directions.

On April 22, 1955, in a rice stubble which appeared to be a common feeding ground for the occupants of the adjacent section of roadside ditch, two males (each already paired) "squared off" in a bitter encounter lasting 3 minutes. There was much chasing both on foot and on the wing and clashing "fighting cock style." W. E. D. Scott (Bent, 1926, p. 287-288) reported similar fighting by Clapper Rails (Rallus longirostris 8cotti) during the courtship period :

"During the mating season the male birds are very pugaacious and resent any intrusions from others of the species. At such time I have them have pitched battles, and finally, one giving in and taking to flight, the victor would pursue the vanquished on the wing for several hundred feet . . .

Sora Rails, migrating through the Arkansas rice country in spring, frequent roadside ditches occupied by King Rails on established nest- 
ing territories. One King Rail made four passes in running flight at a Sora in order to evict it from his territory. Virginia Rails received the same treatment from King Rails.

A call, presumably agonistic, heard when two male King Rails were in the same territory, could be described as kik-kik-kur-r-r-r-.

\section{COURTSHIP BEHAVIOR}

\section{Mating call and pair formation}

With the first warm days of late February, the mating calls of King Rails are heard for the first time in the roadside ditches adjacent to rice stubbles or other fields. Rails feed in the shallow water of the ditch and use the broomsedge (Andropogon spp.) on ditchbanks or outside levees of old ricefields as places of retreat or hiding. Moreover, the rails use little lanes or pathways, such as those made by cottontails (Sylvilagus sp.), for traveling in concealment along the ditchbanks. In late February the only vegetation that offers much concealment to calling King Rails is the perennial ditchbank sedge which is also the winter abode of the Short-billed Marsh Wren on the Grand Prairie; consequently, much of the early season calling emanates from behind or among clumps of this grass. However, where there happens to be an old growth of cattails in the ditch, rails may call from this cover.

The male King Rail calls its mate from a concealed, partly concealed, or completely exposed position. The purpose of this call is first to attract a mate and later, after pair formation, to rally her.

The mating call is one of the least difficult calls to describe. It is most commonly given as a harsh $k i k-k i k-k i k-k i k-k i k$-, but occasionally varies from a series of kiks to a series of kuks or bups. This variation may be a matter of interpretation, possibly depending upon the observer's distance from a calling bird. The pitch of the call is steady, but the tempo increases from time to time. One bird was heard and seen to give this call continuously for 18 minutes. In the Arkansas ricefields this call was heard at almost any time during daylight, but less frequently at night. At Elliott Island, Md., in the Chesapeake Bay country, I often heard the mating call after 10 p.m. D. J. Nicholson (personal communication) heard dozens of these rails calling all through the night on the Kissimmee Prairie, Fla., in January and February 1962.

I have never heard a female give the mating call.

\section{Other calls}

The most characteristic call of the King Rail, the primary advertising call, is the one that is heard throughout the breeding season. It may be written as jupe-jupe-jupe-jupe-jupe- or cheup-cheup-cheupcheup-cheup- or sometimes as gelp-gelp-gelp-gelp-gelp-. The first several notes in a series are louder than succeding ones, and the tempo 
increases rapidly toward the end of the call when the notes run together. One rail gave 25 distinct jupes in a single series, not including those in the rapid ending which could not be counted. This call carries a greater distance than the mating call and is somethimes answered by a number of other King Rails. It is sometimes used when a bird is startled and occasionally serves as an "all is well" call when a pair of separated birds are reunited. In addition, I have often observed an incubating bird using this call when it wishes to be relieved at the nest. The primary advertising call of the King Rail is slower and more deliberate than that of the Clapper, which is usually more of a rapid chac-chac-chac-chac-ohac-.

A call uttered during prenmptial courtship by both the male and the female, but more frequently after pairing, is a soft and rapid tuk-tuktuk-tuk-tuk-. This sound reminds me somewhat of the clapping together of the mandibles of the Barred Owl (Strix varia), and is seldom audible to the human ear beyond 20 or 30 feet. The King Rail uses the "tuk" call as a rallying call or gives it to indicate its position to its mate.

\section{Display}

The display of the male during prenuptial courtship is relatively simple and consists mostly in walking about with tail uplifted and white undertail coverts extended (fig. 21-1). In this position the white undertail coverts can be seen from a considerable distance. While flashing its white undertail coverts, the rail usually flicks its tail up and down slightly. Females that I observed during the period of prenuptial courtship made no attempt to display.

There were other forms of posturing during the period of courtship and mating, but apparently the cocked tail and well-exposed white undertail coverts, accompanied by the mating call, are the principal means of attracting a mate.

On two occasions I observed what appeared to be another form of display, the "pursuit display." The circumstances and the behavior of the male were essentially the same both times. In each case the male apparently had not succeeded in attracting a mate to his territory. On March 1, 1955, at 8:30 a.m., I saw a small and very rufescent King Rail, later established to be a female, moving along a rice levee bordering a roadside ditch and approaching a calling male. The female continued along the water's edge at a slow but steady gait and passed beyond the male that was standing in the ditch. As soon as she was ahead of him, the male followed her at a fast walk with head and neck outstretched, bill open (but emitting no sound audible at 40 feet), tail cocked, and white undertail coverts extended (fig. 21-2).

Following pair formation much of the posturing and calling that characterized the period of prenuptial courtship continues, at least 


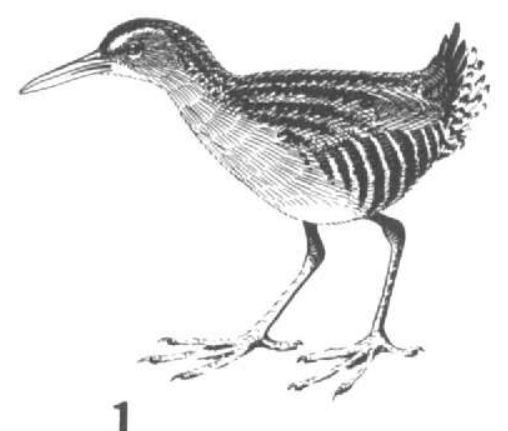

1

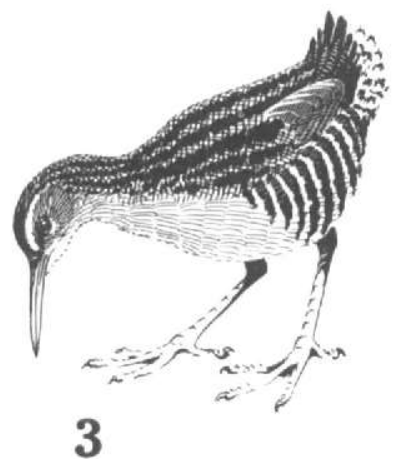

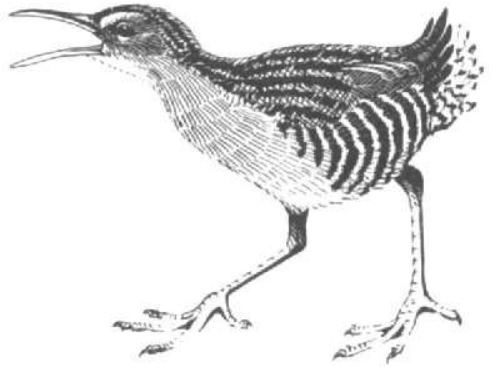

2

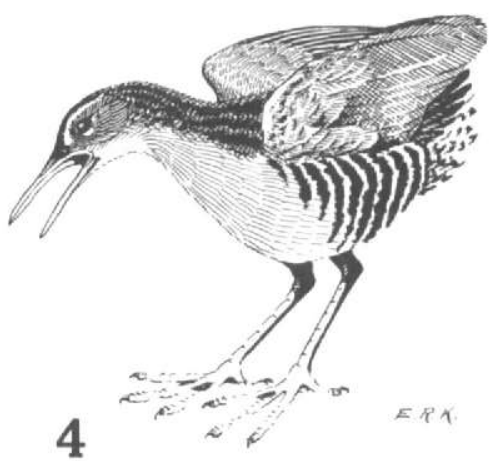

Figure 21.-Displays of the King Rail: (1) In the Advertising Display the tail is cocked and the white undertail coverts extended. (2) The Pursuit Display is given when the male pursues the female during prenuptial courtship; the male walks fast or runs with tail slightly cocked, white undertail coverts extended, and bill wide open. (3) The Invitational Display is assumed by the mated male when the female approaches; the bill points downward and slowly swings from side to side, and the tail is displayed. (4) A variation of the Invitational Display consists in wings arched, head turned to one side, bill open, and tail displayed.

in the earlier phases of nuptial courtship. While pair formation is in progress, but infrequently during the nuptial courtship period, the female utters a purr or churr sound, like the purr of a cat, especially after the male has given the mating call.

The male uses the mating call (kik-kik-) infrequently and with less vigor when rallying a newly won mate which often strays when foraging. I observed a good example of the use of this call shortly after pairing on the evening of March 2, 1955. During an 18-minute period beginning at $5: 30$ p.m., a paired male, while standing partially concealed on a ricefield border levee, uttered the complete mating call seven times. Six of the seven times his mate ran to him from a distance of 100 feet or less where she had been feeding. When the female came up beside him, the male spread his white undertail coverts and bent his head and neck so that his bill was perpendicular to and 
nearly touching the ground (fig. 21-3). From this position, he often turned his bent head with bill open toward the female. At one of these meetings the male appeared to be about to mount the female and begin to rise up with his bill still wide open, but the female evidently was not ready for copulation and walked away.

I observed the same posture many other times, but the birds were usually standing in water. On these occasions the bill usually touched or slightly dipped into the water. Males assumed the pose after pairing, when the feeding female that had been at some distance away came within 3 or 4 feet of her mate. On one occasion a male under such circumstances arched his partly opened wings (fig. 21-4).

\section{Courtship feeding}

Courtship feeding, a type of symbolic display that aids in maintaining the pair bond, was observed during the courtship, egg laying, and incubation periods of the King Rail. In the Arkansas ricefields, the crayfish was the only food that I ever saw presented to a female. In Delaware Bay marshes, the fiddler crab was used for this purpose. The male usually brings the food item to the female, but sometimes he may stand where he catches the crustacean, holding it in his bill, until the female approaches and takes possession.

A mated pair of rails that I observed for a number of days on their Delaware breeding territory would descend at low tide from the marsh to a pool in the bed of a tidal creek. The female would usually stand in the pool while the male hunted food for her. He would frequently run up the winding creek bed for 25 yards or so, catch a fiddler crab, and run back to present it to the female. Why he often traveled such distances when there were plenty of fiddlers nearby is not known.

During a 2-hour period of observation in an Arkansas ricefield, I saw the male of a pair catch seven crayfish, five of which he presented to his mate.

\section{PRENESTING ACTIVITY}

\section{Calling}

As the nesting season approached, the mating call and undertail covert flashing by the male all but ceased, and the addition of a number of calls, mostly soft or subdued, increased the repertoire of the mated pair. Paired rails used such calls as rallying devices when separated or as reassuring answers to one another's calls when together.

A call frequently given by both birds, particularly as nesting approached, was a very soft poyeek-poyeek-poyeek-poyeek-poyeek-, or wyeek-wyeek-wyeek-wyeek-wyeek-, which seemed to act as an inquiry of the whereabouts of the mate.

Several males gave one of the more unusual calls, a deep booming sound requiring an effort which caused the body to appear to expand 
slightly and sounding something like óom-óom-óom-óom-óom-. The purpose of his "booming" call is not known. It is not very loud, and the females were not nearby when it was uttered, unless they were well concealed.

\section{Symbolic nest building}

Symbolic nest building was observed at Stuttgart, Ark. In this case a male King Rail was observed carrying nesting material into a hole in a ricefield dike through which water was draining into a roadside ditch. The dike was about $21 / 2$ feet in height, and the hole was large enough for the bird to pass easily from one side to the other. The light stream of water did not prevent an accumulation of nesting material. However, the nest was not completed. Two days later (April 2) the true nest was started about 10 yards from the hole in the dike.

\section{Copulation}

Copulation usually takes place near the nest site, before and during egg laying. Although no nests with eggs were found on the Arkansas Grand Prairie before March 25, rails were observed copulating as early as March 3, in 2 different years. Perhaps these birds nested earlier than March 25.

On one nesting territory, the male came within 20 feet of the nest (containing one egg), called, and was answered by the female who left the nest and came to the male for copulation. The jupe-jupe-jupejupe-jupe-call often precedes copulation during this period. Copulation is performed with the female assuming a crouch and the male mounting with legs and feet placed on the female's back.

\section{NESTING PERIOD}

The nesting period varies with latitude, being longer and starting earlier in the southern part of the range. The nesting period in Florida extends from late January, at least, until the middle of July, and in Louisiana from early March to September. It is quite conceivable, therefore, that in such States as Florida and Louisiana the breding season covers 7 to 8 months. Unlike the Bobwhite (Colinus virginianus), Redwinged Blackbird, and several other species which do not nest much earlier in the gulf coast region than in the northern States, the King Rail takes advantage of the long warm period, and nests over a longer period of time. The long period of nesting in the South should result in a greater total production of young, because of the much greater opportunity for renesting and second broods. The nesting season in the Middle Atlantic States is about 4 months; adults with downy young have been observed in early August in Delaware. 
With the long warm period prevailing in the Deep South, time for raising more than one successful brood would seem to be ample. A breeding pair is busy with nesting activity for about 2 months (approximately 10 days for laying, 21-22 days for incubation, and 24-30 days with brood). As yet there is no evidence that the King Rail is double-brooded; however, no attempt has been made to determine this. The closely related Clapper Rail in South Carolina is double-brooded (Blandin, 1963, p. 66-67), and it is probable that some King Rails in the Deep South also have more than one successful brood during a season.

A nest found in a cypress pond in southern St. Johns County, Fla., in February 1933 contained 11 eggs in an advanced stage of incubation (Hallman, 1934, p. 18). Allowing a 21- or 22-day incubation period plus 11 days for laying, it is conceivable that this nest was started in January. D. J. Nicholson found a dead King Rail at Orlando, Fla., on February 16, 1925, with a hard-shelled egg ready for deposit (Howell, 1932, p. 203). A single downy young King Rail was seen on March 10, 1950, 2 miles west of 40-mile Bend, Dade County, Fla., by J. C. Moore and D. B. Beard (U.S. National Park Service files). W. B. Robertson, Jr. (personal communication), found several young King Rails at Royal Palm Hammock, in the Florida Everglades, on March 5, 1952. These last two examples indicate February nesting.

Adults with six young approximately 2 weeks old were recorded in Lee County, Fla., July 30, 1966, indicating that the nesting season in Florida extends into July (Frederick H. Lesser, personal communication).

At Oakland Plantation, a few miles north of Charleston, S.C., a brood of 10 young were seen by Francis Porcher on March 22, 1913 (Sprunt and Chamberlain 1949, p. 193). In this case nesting started in early or mid-February. I found young 1 to 4 days old (egg tooth present) and a nest of nine eggs in Jasper County, S.C., near Savannah, Ga, on April 16, 1961, and young at Georgetown, S.C., on April $25,1961$.

At Grand Chenier, Cameron Parish, on the southwestern coast of Louisiana on April 8, 1956, I observed a pair of King Rails feeding 2-week-old young. Back-dating about 38 days to cover the age of the young and the incubation period, laying began about March 3.

Fifty miles north in the Louisiana rice country, nesting probably gets underway a little later than on the coast. A nest of seven eggs was found at Mamou, March 30, 1957. A late nest containing eight eggs was found at Mamou, August 6,1955.

On the Arkansas Grand Prairie, the important nesting months are April, May, and June (table 8). The earliest indication of nest build- 
ing is in late March (March 25). During March 1952, nearly all King Rails seen were in pairs.

In Maryland, most clutches are laid between May 15 and June 30. A brood of chicks and their parents were seen by P. J: Van Huizen near the Blackwater River, Dorchester County, on May 21, 1965, giving evidence that some King Rails begin nesting in April.

In Central Ohio, Milton B. Trautman and R. Bales located 42 nests, 34 of which were found in May and 8 in June (M. B. Trautman, personal communication). Seven of the June nests were found during the first half of the month, and 26 of the May nests were found during the last half of that month. From this, the main nesting period seems to extend from May 15 to May 31.

TABLE 8.-Nesting dates, clutch size, and habitat of King Rail nests at Stuttgart, Ark.

Nest
num- Date found
ber

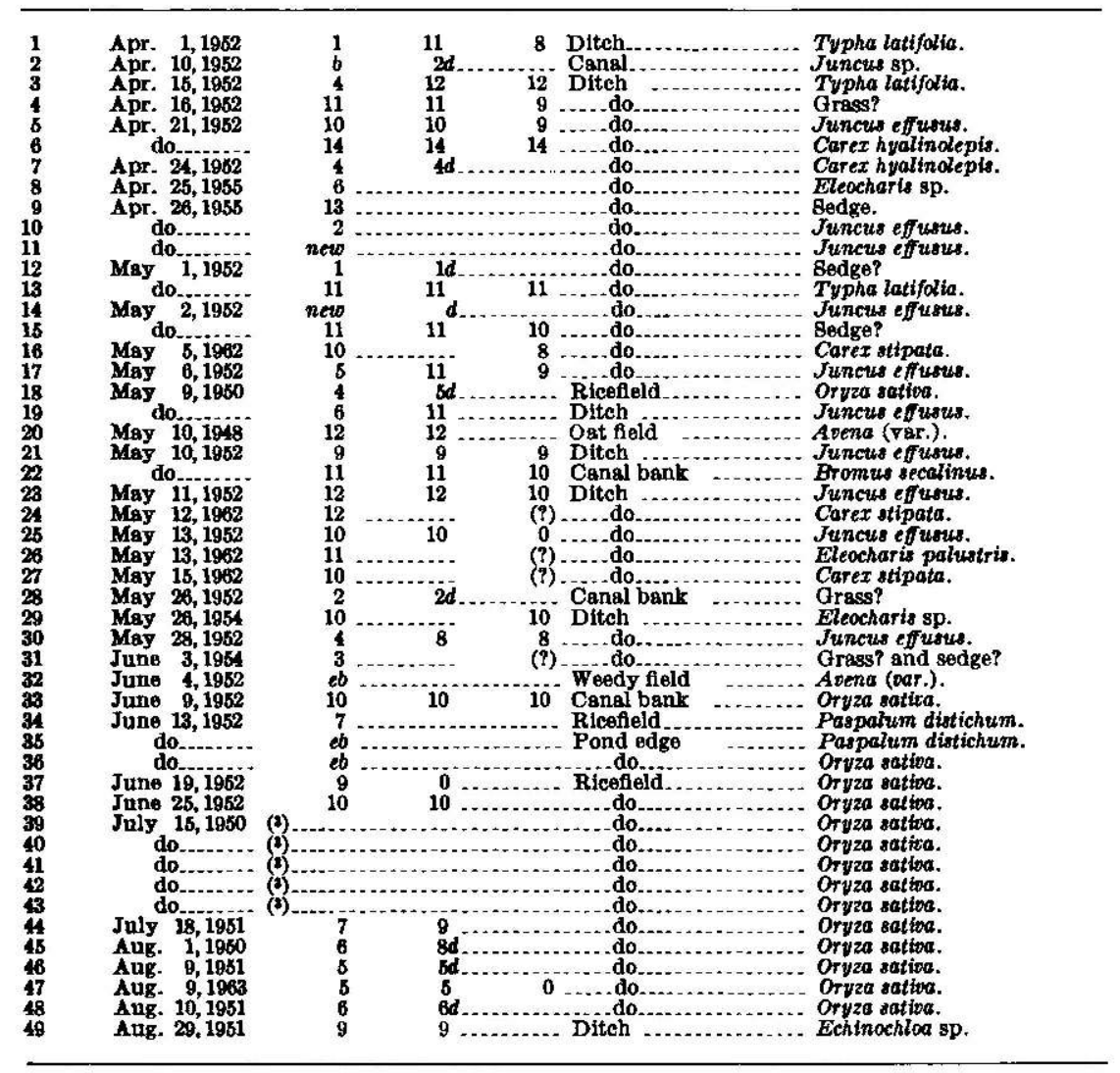

$1 b=$ bulliding; $b=$ eggs broken.

Nest and eggs found; clutch size not recorded. 
Tanner and Hendrickson (1956, p. 54) reported that in Clay County, Iowa, nesting begins soon after the arrival of the birds during the first week of May.

In 1951 the nesting season extended for a period of 42 days from May 13, the date that the first egg was laid, until June 23, the date that the last egg hatched.

\section{NEST SITE AND MATERIALS}

The usual nest site is in the shallow-water part of a marsh. The water depth was 4 to 18 inches at Clay County, Iowa (Tanner and Hendrickson 1956, p. 55), 2 feet at Buckeye Lake, Ohio (Trautman 1940, p. 229), and 6 to 8 inches in Arkansas ricefields. In South Carolina, Wayne $(1910$, p. 35) found nests in buttonbushes 8 to 18 inches over water.

In a giant cutgrass marsh near Savannah, Ga., each of five nests located was within 20 feet of the edge of the marsh, although the vegetation density and other characteristics appeared uniform over extensive areas.

Occasionally a nest is placed on a dry-land site such as an oat or wheatfield, or on a grassy embankment. In 1952, on Long Island, N.Y., Roy Latham (1954, p. 3-9) found a nest on the ground in a potato field, 150 yards from the edge of a salt marsh where Clapper Rails were nesting.

The nest site appears to be chosen by the male. On two occasions, I have seen a male initiate nest-building.

Most King Rail nests are placed in fairly uniform stands of vegetation and are well concealed, but the shape of the nest canopy (whether cone-shaped or round) sometimes disrupts the uniform pattern of the vegetation and reveals the location of the nest to the human eye (figs. 22 and 23 ).

The life form of some plant in the territory, such as a tussock of grass or the stool of a rice plant, often determines the exact nest site. A nest may be placed in a clump of grass or a sedge tussock, or between several clumps, parts of which are used in fashioning the canopy and sides of the nest. The bases of most Arkansas nests were made of wet decaying plants, and the platforms or cups were of dead dry grasses, sedges, or rushes. These materials are obtained near the nest site. The base of one nest found in Arkansas was made entirely of mud and was $21 / 4$ inches in depth.

Nest materials used in some Iowa nests consisted of one or two species of plants (Tanner and Hendrickson 1956, p. 55). Most nests in Arkansas ricefields were made of rice plants; a few were made from "weed" plants in the fields, such as wild millet. The completed nest is a round, elevated platform with a saucer-shaped depression (figs. 23,24 , and 25). It usually has a round or cone-shaped canopy and a ramp, and is nearly twice as large as that of the Virginia Rail or Sora. 


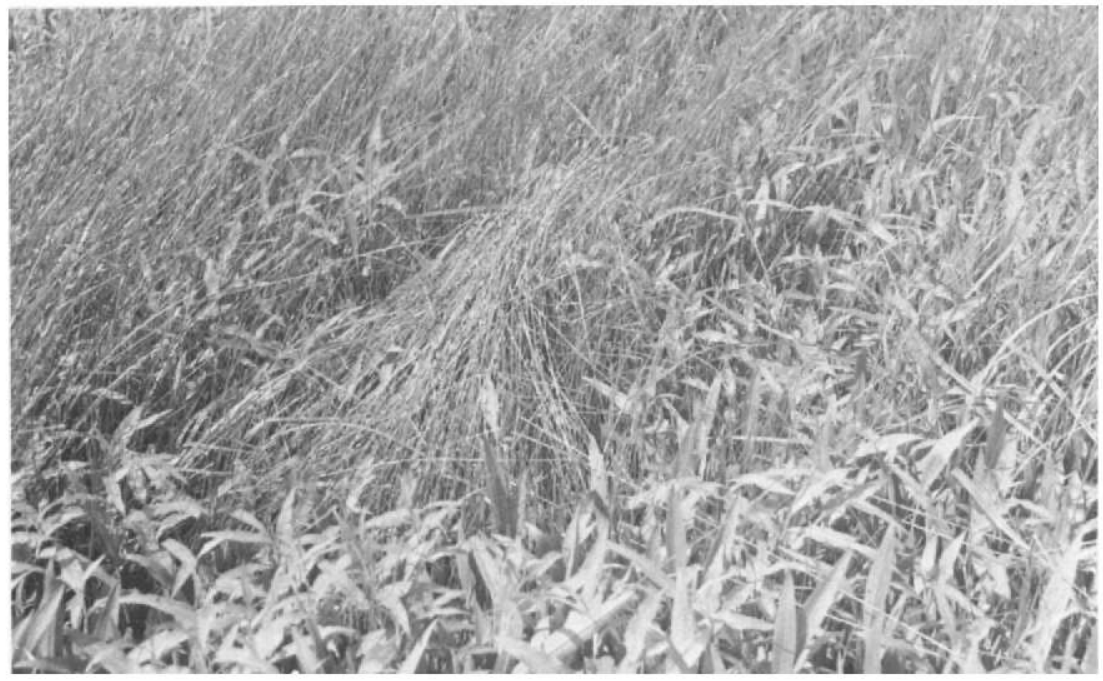

FraUaE 22.-Canopy of King Rail nest in roadside ditch, Arkansas Grand Prairfe. In a uniform stand of vegetation the canopy is often quite conspicuous. Canopy composed of spikerush (Eleocharis palustris) and smartweed (Potygomum sp.).

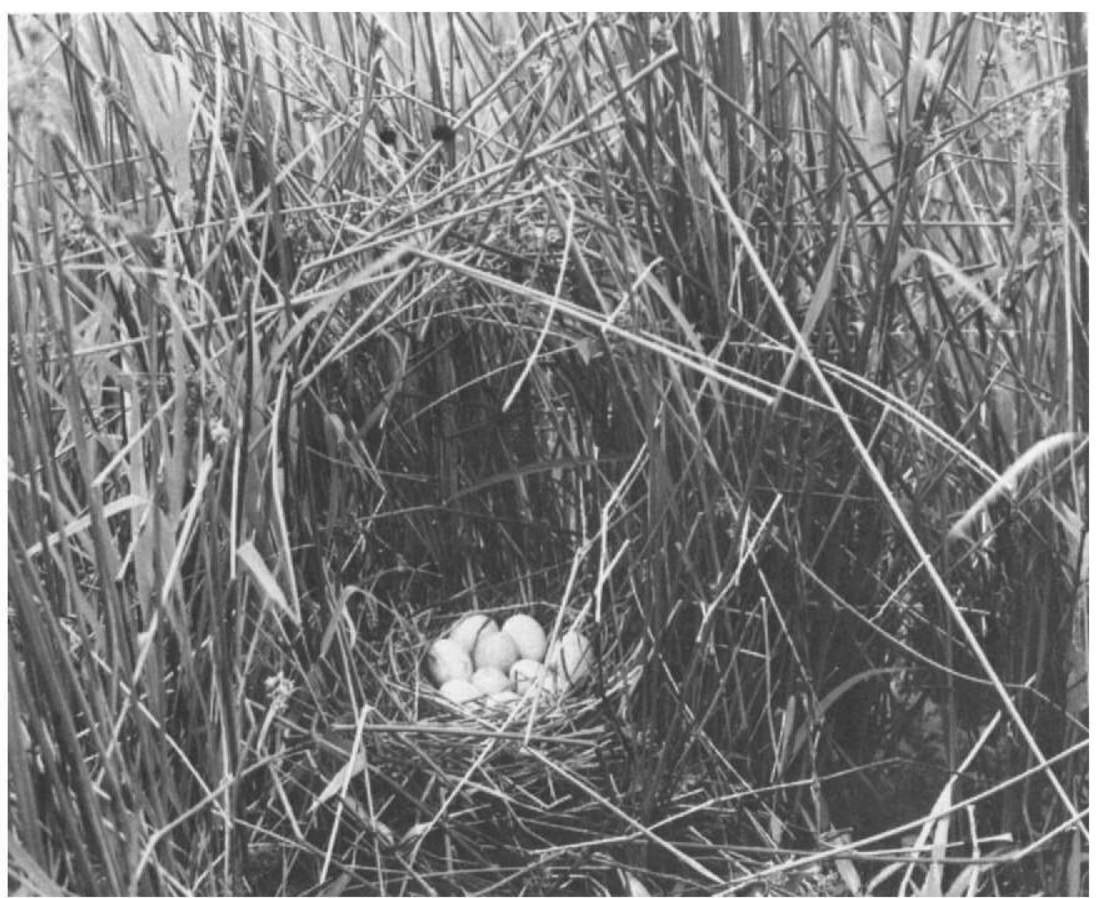

Froubs 23.-King Rail nest in roadside ditch near Stuttgart, Ark., May 30, 1952. Nest constructed of softrush (Juncus effusus). 


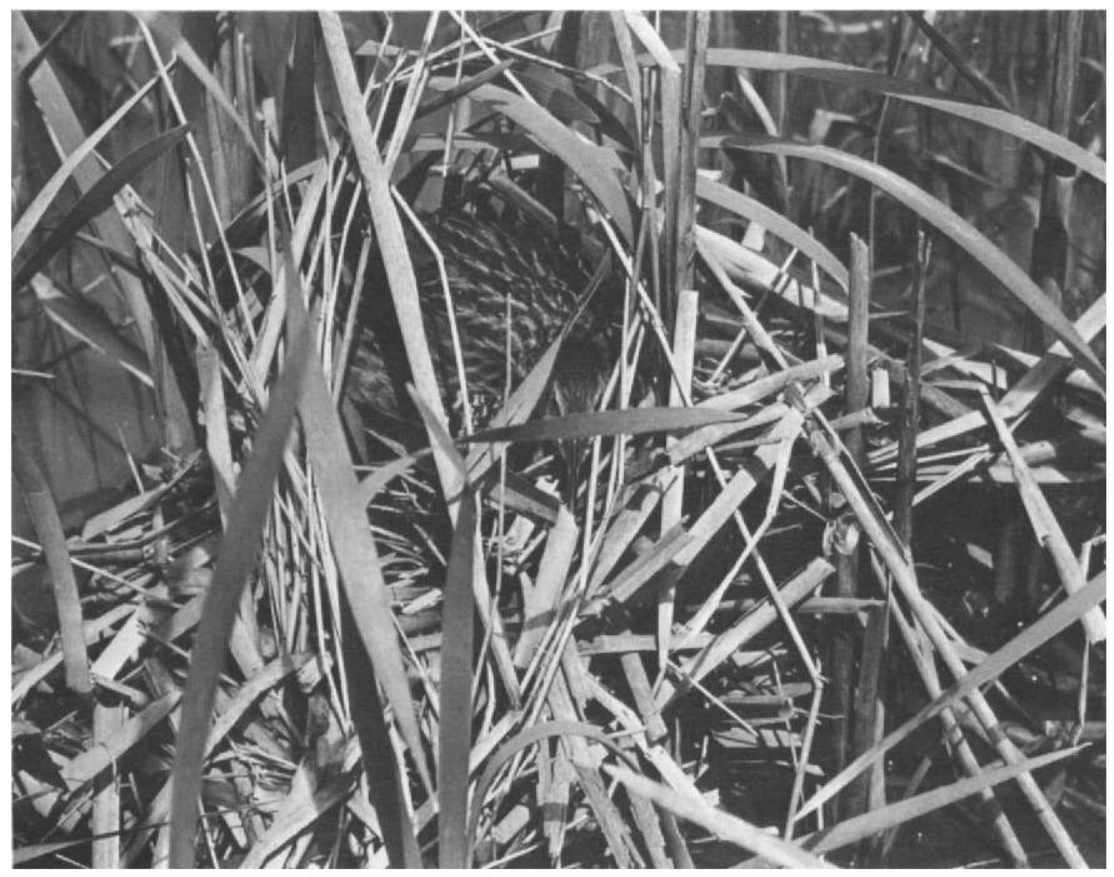

Frauke 24.-King Rail incubating in nest constructed of cattalls (Typha tatifolia) in raadside ditch, Arkansas Grand Prairie, April 1952.

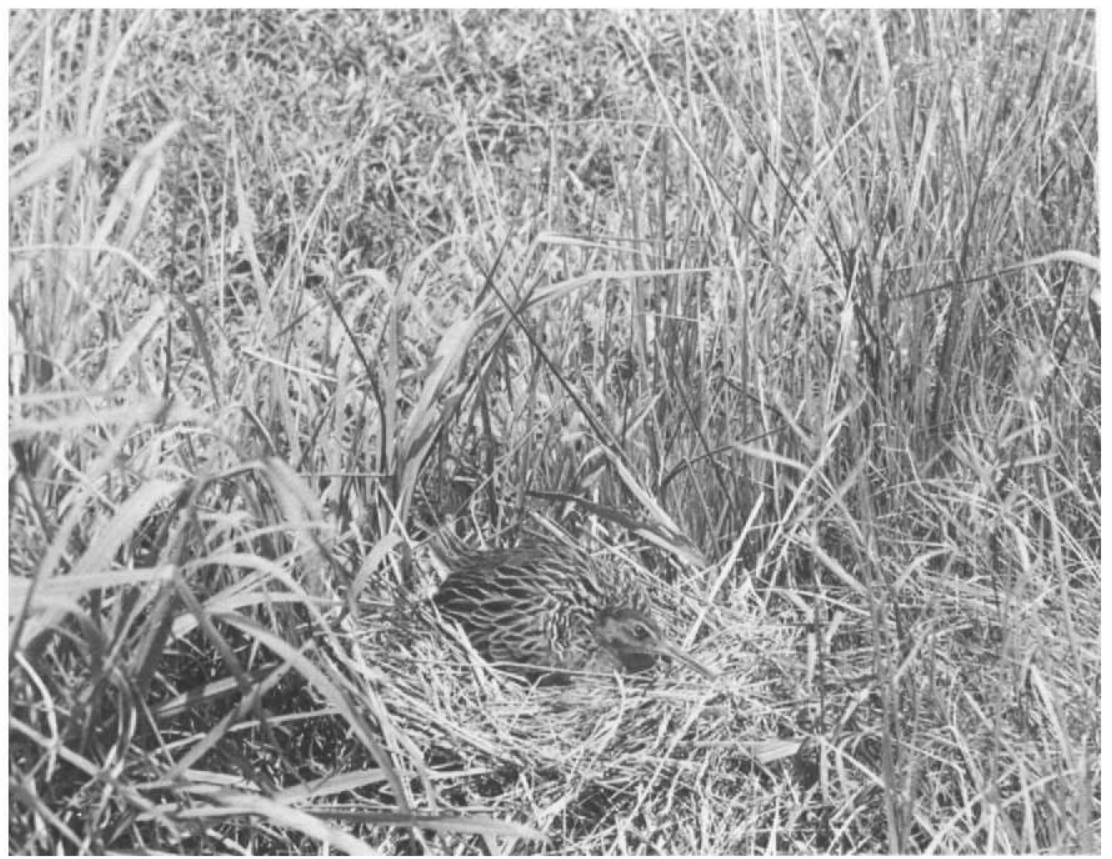

Frgure 25.-King Rail incubating in open nest along roadside ditch, Mamou, La., April 1857. 
Dimensions of 11 eastern Arkansas nests were: average height from ground to canopy, $43.0 \mathrm{~cm}$; ; average height from ground to rim, 16.5 $\mathrm{cm}$.; average exterior diameter, $28.0 \mathrm{~cm}$.; and inside depth, $1.5 \mathrm{~cm}$. (Meanley, 1953, p. 265).

The height of the nest above water usually depends upon the depth of the water. Eggs in most nests in Arkansas Grand Prairie ricefields were less than a foot above the water level. In tidal marshes along the lower Savannah River, S.C., the eggs in two nests were about 2 feet above the low tide mark and about 1 foot above the high water mark. Nests in dry locations, such as oatfields, canal banks, or dry ditches, are usually elevated very little, and the eggs may rest within an inch or two of, or actually on, the ground. Nests placed above 2 or 3 inches of water may be elevated as much as a foot during a heavy rain or when a dry ricefield is being flooded.

After a heavy rain on the Arkansas Grand Prairie, an incubating rail was observed working rapidly to build up its cattail nest above the rising water in a roadside ditch. By reaching ont with its bill all around the nest and picking up materials (mostly cattail leaf fragments), which it tucked beneath the eggs, and by using most of the canopy for the same purpose, the bird managed to keep the eggs about 2 inches above the rising water. The ditch was nearly dry before the rain, and the eggs were then 5 inches from the ground. At peak depth, the water was 21 inches deep. On another occasion, a nest with eggs $2 \mathrm{x} / 2$ inches from the ground was located in a ricefield that had been temporarily drained. The next day, the field was flooded to a depth of 5 inches, and the eggs were raised to 7 inches from the ground. As the water continued to rise, the incubating bird persisted in elevating the eggs by tucking rice leaves from the canopy under them.

On one occasion I came upon a bird constructing a nest on a canal bank, and watched the process only a minute or so before its mate came to continue the work. The bird that was relieved left to feed in a nearby ditch. I watched the newcomer for about 3 minutes, and then collected it. Upon dissection it proved to be the male.

Apparently the male takes the more active part in nest building. Males on three occasions were observed gathering nest material within 20 feet of the nest site. A captive male purred like a domestic cat constantly as it carried nesting material to the nest site. The nest is shaped as the bird (all observations were of males) sits in a clump of grass or between clumps and semirotates its body. It later piles up dead vegetation, and shapes the cup. The canopy is formed by bending over the tops of stalks of adjacent plants. One Arkansas nest was observed under construction at 8 a.m. and $6: 30$ p.m. of the same day, another one at $12: 15$ p.m. and $5: 15$ p.m.

The nest is not always completed before the first egg is laid. While driving along a paved road 5 miles south of Stuttgart, Ark., at $5: 30$ 
p.m. one day in May, $\mathbf{I}$ heard two rails uttering their characteristic jupe-jupe-jupe-jupe-jupe call. One of the birds was standing in a nearby ditch, and after about 3 minutes of watching, I saw the grass move on the bank near the rail in view. As the same grass continued to move, it was evident to me that the mate was building a nest. Actually the bird was pulling in grass to form the sides and canopy for a nest. After watching it for a few minutes I departed. The next morning I found that construction was in the initial stage, but two eggs had been laid on the bare ground and were surrounded by just a few dead plant fragments.

A Purple Gallinule, another species of Rallidae, was reported by Grimes $(1944$, p. 63$)$ to have a nest platform 6 inches thick when the first egg was laid. As the eggs began to hatch, the nest was built up until it was 13 inches thick.

Similar nest building activity by Clapper Rails at Frogmore, S.C., was reported by Hoxie (1887, p. 181) :

The first time I found the nest it contained only one egg, and did not seem wide enough to hold more than one more. . . . As each new egg was laid they added fresh material to the outside, until the nest was at least amply sufficient to contain the full set of eight.

Several brood nests, usually without canopies, are constructed near the egg nest.

\section{EGG LAYING AND CLUTCH SIZE}

Eggs were deposited daily at five Arkansas nests. In one Arkansas nest, the eggs were laid between 7 p.m. and 7 a.m. In one South Carolina nest, Wayne $(1910$, p. 36$)$ noted that each egg was deposited after 11 a.m.

Parasitism or "dumping" was recorded by B. H. Swales (1896, p. 142) in St. Clair County, Mich. On June 9, a King Rail was flushed from a nest containing $17 \mathrm{eggs}$; nine were apparently laid by the King Rail, seven by a Virginia Rail, and one by a Sora.

\section{Clutch size}

Clutches of 10,11 , or 12 King Rail eggs are most frequently found (table 9). A smaller clutch may represent a replacement clutch, depending upon when it occurs. On the Arkansas Grand Prairie, the earliest clutch of eight eggs was found on May 28, approximately 2 months after the beginning of the laying season. In Maryland, in July, I observed three complete clutches of six eggs each.

\section{Description of eggs}

Bent (1926, p. 261) gives the following description of the eggs:

They are ovate in shape and the shell is smooth and slightly glossy. The ground color averages lighter than in eggs of the clapper rails, but not so light as in 
those of the California species; it is pale buff, varying from "cream buff" to "pale olive buff." They are sparingly and irregularly spotted, mostly in small spots, with various shades of "vinaceous drab," "army brown" and "vinaceous brown" and sometimes with a few spots of brighter browns. The measurements of $56 \mathrm{eggs}$ averaged 41 by 30 millimeters, the eggs showing the four extremes measure 44 by $32,38.5$ by 28 millimeters.

I measured 20 eggs at Stuttgart, Ark. two from each of 10 nests. The average measurement was 40.8 by 30.4 millimeters, with extremes of 42.0 by 32.0 and 39.5 by 29.5 .

Table 9.-Clutch sizes in King Rail nests at three locations

\begin{tabular}{|c|c|c|c|}
\hline \multirow[b]{2}{*}{ Clutches with- } & \multicolumn{3}{|c|}{ Number of clutches found } \\
\hline & $\begin{array}{l}\text { Stuttgart, } \\
\text { Ark. }\end{array}$ & $\begin{array}{l}\text { Northern } \\
\text { snd central } \\
\text { Ohio : }\end{array}$ & $\begin{array}{l}\text { Delaware } \\
\text { Valley }^{3}\end{array}$ \\
\hline 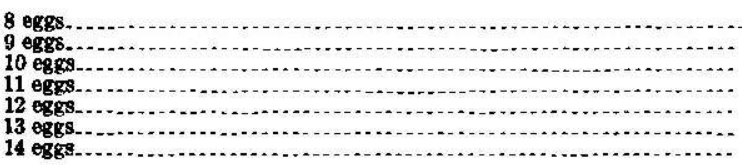 & $\begin{array}{l}1 \\
3 \\
7 \\
3 \\
1 \\
1\end{array}$ & $\begin{array}{r}3 \\
1 \\
9 \\
11 \\
9 \\
3 \\
1\end{array}$ & $\begin{array}{r}1 \\
3 \\
3 \\
2 \\
4 \\
1\end{array}$ \\
\hline Mean number of eggs & 11.2 & 37. 9 & 14.6 \\
\hline
\end{tabular}

1 Meanley, unpublished.

2 Trantman, 1940, p. 229; R. Bales, ms.

2 Stone, 1937, p. 332; R. F. Miller, correspondence.

\section{Weight of eggs}

At Stuttgart, Ark., three eggs weighing 18.9, 20.3, and 18.8 grams were marked on the day they were laid and were weighed on every seventh day until hatching (table 10). The average weight loss was 0.47 gram during the first week, 0.83 gram during the second week, and 1.0 gram during the third week. The average total loss from laying to hatching was 2.30 grams.

\section{INGUBATION}

The incubation period is about 21 or 22 days. Roberts (1936, p. 440) stated that A. M. Bailey found the incubation period to be about 21 days. In Clay County, Iowa, Tanner and Hendrickson (1956, p. 55) found it to be approximately 21 days. Incubation periods of four Arkansas clutches were 21 days, 22 days, 22 or 23 days, and approximately 23 days.

One Arkansas nest was under daily observation from the time the first egg was laid on April 1 until the last egg hatched on May 4. Eleven eggs were in the completed clutch, and incubation started with the laying of the 10th egg on April 10. At another nest in Arkansas incubation began on April 22 or 23, and the eggs hatched on May 13 and 14. A nest at Mamou, La., contained 9 eggs on June 9 and 10 hatching eggs on June 30. 
Both sexes incubate. To prove this, one night between 9 and 10 p.m., I placed white paint in a small can at the end of a long stick and poured it on the backs of incubating birds at two nests. On subsequent visits to the nests, unmarked birds were often seen incubating.

TABLE 10.-Weight loss in three King Rail eggs during incubation [Tn grams]

\begin{tabular}{|c|c|c|c|c|}
\hline & \multicolumn{4}{|c|}{ Weight on- } \\
\hline & Day 1 & Day 7 & Day 14 & Day 21 \\
\hline $\begin{array}{l}\text { Egg } 1 \\
\text { Egg } \\
\text { Egg } \\
\text { Z }\end{array}$ & $\begin{array}{l}18.9 \\
20.3 \\
18.8\end{array}$ & $\begin{array}{l}18.7 \\
19.5 \\
18.4\end{array}$ & $\begin{array}{l}17.8 \\
18.8 \\
17.6\end{array}$ & $\begin{aligned} 16.7 \\
17.9 \\
\end{aligned}$ \\
\hline Mean & 19.33 & 18.86 & 18. 03 & 17.3 \\
\hline
\end{tabular}

1 Clutch destroyed.

Later that season an exchange of sexes was observed at a nest during the incubation period. At 5:18 p.m. an incubating bird called from the nest, whereupon its mate immediately came from the cattails across the road to a point about 20 yards from the nest, and began walking toward the nest until it was within 5 feet. The incubating bird then left the nest and was replaced by its mate, which remained on the nest for 17 minutes, when an exchange again took place.

In another instance, when one member of an Arkansas pair nesting near a road was killed by an automobile, its mate continued to incubate the eggs. An incubating bird caught on a nest at $5: 45$ p.m. May 16, was a male.

Incubating birds seldom flush until an intruder is within 10 feet or less of the nest. As the hatching date approaches, they become more tenacious. On several occasions I was able to band incubating birds, but not without considerable resistance from them. On one occasion when I approached a nest at hatching time, the bird flew from the nest and struck me in the chest. On other occasions birds have struck at my legs or have run to my feet where they remained with wings outstretched. Frequently they feigned injury by spreading the wings, fluttering through the vegetation (fig. 26), and uttering a distress call which might be written as a gutteral rack-k-k-, rack-k-k-, rack-k-k-, sometimes varying to sound like chur-ur-ur-ur (the roll on the ur is like the German " $R$ "). Other scolding notes given by a rail flushed from its nest are a resonant gip-gip-gip- and kik-kik-kik-.

In contrast to this type of behavior, the Clapper Rail is usually gone before the intruder gets near the nest. At Chincoteague, Va., I have examined some 200 Clapper Rail nests, and only on some half dozen occasions has an incubating bird remained while approached to within 10 feet. This appears to be a striking behavioral difference between these two closely related species. 


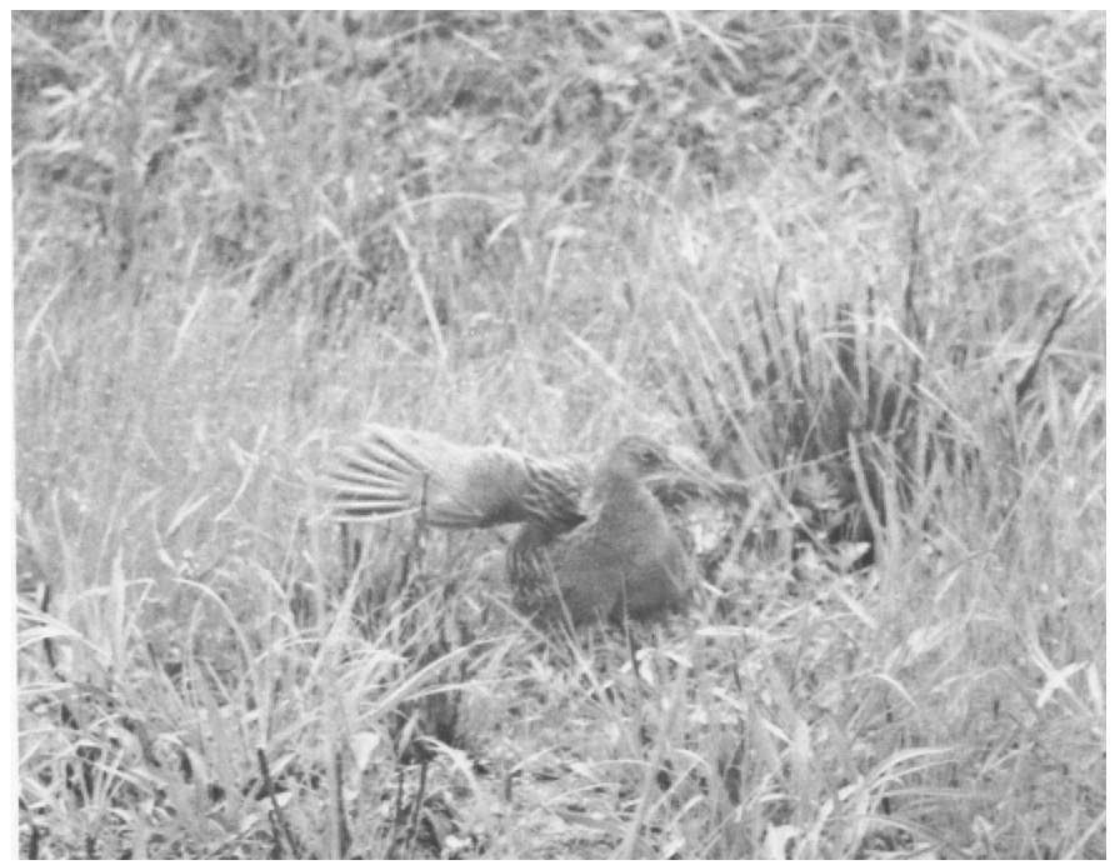

Fraurs 26.-Distraction display of King Rail near nest. This display is characterized by feigning injury and emitting distress call.

\section{HATCHING}

Eggs in four Iowa nests hatched within a 24 - to 48-hour period, and were pipped from 24 to 48 hours before hatching (Tanner and Hendrickson, 1956, p. 55).

Hatching was observed at Stuttgart, Ark., May 26-29, 1954. When located at 12 noon on the $26 \mathrm{th}$, the nest contained $10 \mathrm{eggs}$, only one of which showed signs of hatching and had two small pip holes. By 4:30 p.m. the following day (May 27), 9 of the 10 eggs were pipped. At 1 p.m. May 28, 3 eggs had hatched; by 5:30 p.m. that evening, 5 eggs had hatched; and by 10 a.m. May 29, all eggs had hatched. At 4 p.m. May 29, the entire brood and both parents were at the nest; but at $9: 30$ p.m. the entire family had deserted the nest and was probably spending the night in a nearby brood nest.

At one Arkansas nest the parent birds alternately participated in brooding newly hatched young and hatching eggs. Toward the end of the hatching period the nonbrooding parent was usually observed within 25 feet of the nest, accompanied by several of the chicks.

As eggs hatch the shells are disposed of in several ways. One brooding bird at an Arkansas nest ate most of an egg shell about 5 minutes after the egg had hatched. Shell fragments were found in the stomachs of several adult birds collected during the breeding season. Some shells 
remain in the nest, disintegrate, and eventually filter down into the base of the nest. Shell fragments are found in virtually all nests that have hatched young.

A pair may remain with their brood for more than a month after hatching. I have collected three-fourths grown young rails that were still traveling with an adult pair in August. In one instance a pair, one of which was marked, and their 3-day-old young still spent most of the day within 20 yards of their nest, and 19 days later were seen only 10 yards from the nest ! Once I came upon a brood of young King Rails approximately 3 weeks old traveling with three adult birds.

The call given by an adult with young chicks when all is well is a soft continuous woof-woof-rooof- (corresponding to the cluck-cluckcluck- of a barnyard hen). An alarmed parent with brood emits a sharp gip-gip-gip-, which causes the young to scatter to a hiding place.

\section{NESTING SUCGESS AND SURVIVAL}

In Clay County, Iowa, Tanner and Hendrickson (1956, p. 55) found that four of six observed nests hatched one or more eggs each. Of 60 eggs in the six nests, 39 hatched.

Of 16 Arkansas nests I observed, 12 hatched one or more eggs each. The average number of eggs hatched in each of these 12 nests was 9.9. Of a total of 147 eggs in all 16 nests, 119 hatched.

An index of survival based on the number of young over 2 weeks of age is difficult to obtain because complete broods are not always seen. In Arkansas, I observed 10 broods with what I believe were full complements. In each observation, the parent birds were unaware of my presence as the family was crossing a road, feeding in a newly sown ricefield, or moving about in some other comparatively open spot. The number of young per brood ranged from two to nine and averaged five. If my estimate of an average hatching success of 9.9 is correct, then survival rate until 2 weeks of age was about 50 percent.

\section{BREEDING STATUS OF FIRST-YEAR BIRDS}

Although $I$ know of no example of juvenile or immature birds being marked and recaptured in breeding condition or in the act of nesting, I collected a nesting bird in what appeared to be first-year plumage in the Delaware Bay marshes. Only the lower throat and upper breast regions of this bird were cinnamon, a whitish area covered most of the lower breast and axillary regions, and the side of its head was considerably paler than average for mature birds. The greater coverts were heavily barred with whitish subterminal bars. The specimen, a female, was extremely small. Measurements were as follows (with adult female average in parentheses): Wing $147.0 \mathrm{~mm}$. (154.3); exposed culmen $54.0 \mathrm{~mm}$. (61.9); tarsus $50.0 \mathrm{~mm}$. (54.0). 


\section{Development and Behavior of Captive Rails}

\section{DEVELOPMENT OF YOUNG}

\section{First-day chick}

The newly hatched King Rail is very weak and wet. Contrary to the statements of Audubon (1835, p. 28) and Howell (1932, p. 203), it is unable to run about and follow its parents as soon as it is hatched. Sometimes it emerges from the shell on its back and lies kicking and struggling for some minutes before righting itself. A nest mate may grab its toes or beak and so stimulate further activity. Most of the chicks I have observed were more than an hour old before they were able to go over the side of the nest and return. Chicks 15-20 minutes old had considerable difficulty when we placed them in weeds and water outside their nest, and they could not get back into the nest under their own power.

As the down dries out, the young bird moves more actively about the nest, the undeveloped wings assisting in this effort. As the rail chick begins to gain strength, it sits on its tarsi and assumes a begging display, with wings extended for balance.

The period of fluffing-out often takes half an hour or longer. It took $4 \frac{1}{2}$ hours for one of the chicks I observed. The fluffing-out process may be necessary to produce buoyancy needed to enter the water safely, as Gullion $(1954$, p. 389) suggests for the Coot (Fulica americana).

Chicks took food from their parents' beaks the first day, but I did not see them picking up food from the ground until the second day.

The day-old chick has at least two calls: a loud begging call, cheeup; and a soft lower-pitched call of contentment, wee and wee-up.

The day-old chick is covered with black down that has a faint greenish sheen or cast except in areas where it is most dense. The down is very dense on the abdomen and sparse on the crown. The bill has a pied pattern; the basal half of the bill is grayish black, the narial region is white, the distal portion is flesh-colored, and the egg tooth, retained at the tip for 4-6 days after hatching is white. The legs and feet are brownish gray although, at a quick glance, they appear to be black. Eyes are grayish brown. A vestigial claw is present on each wing. 
The young bird loses weight throughout the first day of life. One female chick weighed 16.3 grams at hatching, 16.0 grams at 1 hour, 15.7 grams at 2 hours, and 13.2 grams at 24 hours (table 11).

\section{One to thirty days}

During the first month of life the major change in the appearance of the King Rail chick is one of size and conformation (fig. 27). A young captive male weighed 16.7 grams when he was $1 \frac{1}{2}$ days old, and 96.3 grams when he was a month old. His measurements at $11 / 2$ and 30 days, respectively, were: exposed culmen, 11.0 and $28.0 \mathrm{~mm}$; tarsus, 20.0 and $42.0 \mathrm{~mm}$; middle toe with claw, 22.0 and $50.0 \mathrm{~mm}$. (table 11.).

The thick natal down is present during most of the first month, but during the fourth week there is evidence of development of the juvenal plumage.

TABLE 11.-Growth of four King Rails

\begin{tabular}{|c|c|c|c|c|}
\hline \multirow[b]{2}{*}{ Age } & \multirow{2}{*}{$\begin{array}{c}\text { Weight } \\
\text { (grams) }\end{array}$} & \multicolumn{3}{|c|}{ Length of- } \\
\hline & & $\begin{array}{l}\text { Exposed } \\
\text { culmen } \\
\text { (mm.) }\end{array}$ & $\begin{array}{l}\text { Middle toe } \\
\text { with claw } \\
\text { (mm.) }\end{array}$ & $\begin{array}{l}\text { Tarsus } \\
\text { (mm.) }\end{array}$ \\
\hline $\begin{array}{l}\text { Hatched. } \\
1 \text { hour } \\
2 \text { hours } \\
1 \text { dsy } \\
8 \text { days } \\
21 \text { days } \\
60 \text { days } \\
90 \text { days }\end{array}$ & $\begin{array}{r}16.3 \\
16.0 \\
15.7 \\
13.2 \\
14.0 \\
40.0 \\
202.0 \\
265.0\end{array}$ & $\begin{array}{l}11.0 \\
12.5 \\
19.5 \\
40.0 \\
49.0\end{array}$ & $\begin{array}{l}20.0 \\
26.0 \\
36.0 \\
67.0 \\
57.0\end{array}$ & $\begin{array}{l}20.0 \\
21.5 \\
29.0 \\
53.0 \\
53.0\end{array}$ \\
\hline 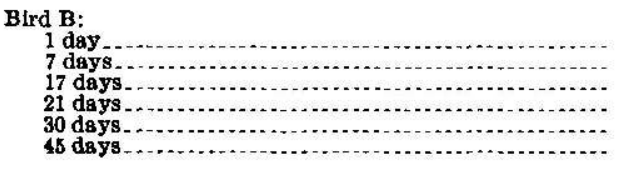 & $\begin{array}{r}15.6 \\
18.9 \\
37.0 \\
80.7 \\
75.4 \\
177.9\end{array}$ & 20.0 & 49.0 & $\begin{array}{l}38.5 \\
52.0\end{array}$ \\
\hline 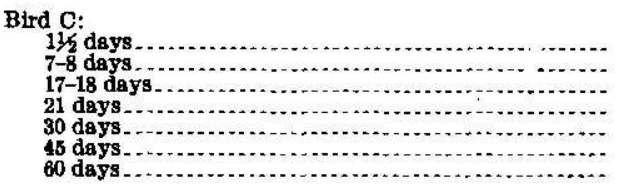 & $\begin{array}{r}16.7 \\
25.7 \\
46.5 \\
63.8 \\
96.3 \\
219.8 \\
327.0\end{array}$ & $\begin{array}{l}11.0 \\
21.0 \\
28.0 \\
40.0 \\
18.0\end{array}$ & $\begin{array}{l}22.0 \\
36.0 \\
50.0 \\
61.0 \\
61.0\end{array}$ & $\begin{array}{r}20.0 \\
32.0 \\
-62.0 \\
66.0 \\
58.0\end{array}$ \\
\hline 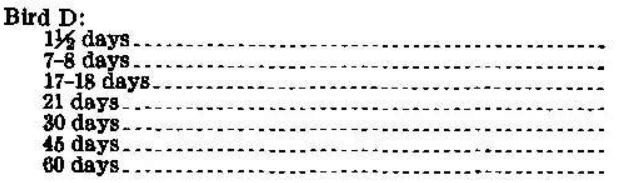 & $\begin{array}{r}16.6 \\
19.7 \\
32.0 \\
47.7 \\
70.8 \\
176.0 \\
268.6\end{array}$ & 25.0 & 43.0 & 36. \\
\hline
\end{tabular}

I Wet.

Toward the end of the first month the young rail begins walking more deliberately and assumes the gait of the adult bird. When it is seeking food, it tips its tail in typical adult fashion. Tail tipping was observed in one 2-week-old chick. 
Month-old King Rails have at least four calls: (1) seep-seep-seep(repeated) indicates general satisfaction and, particularly, acknowledges the presence of others and notifies them of its presence; (2) tah-ee! tah-ee! (repeated), very high pitched and progressively lower in volume as sleep approaches, indicates relaxed comfort and sleepiness; (3) soo, tsoo (tsŏo) indicates lonely dissatisfaction; (4) keelpkeelp-keelp-, a series of five or six hoarse notes in rapid sequence, expresses protest.

\section{Thirty to sixty days}

During the second month the juvenal body plumage replaces the natal down. The first juvenal feathers may be obscured by down until the young rail is nearly a month old, but by the seventh or eighth week the development of nearly all of the body feathers is complete. The plumages of four captive King Rail chicks developed at about the same rate through the first 6 weeks, but the rate varied considerably thereafter.

The first evidence of change from the natal down plumage is the appearance of white auricular tufts and pale juvenal feathers on the underparts and flanks (figs. 27 and 28). Feather development in these areas during the fourth week is as follows:

(1) The sternal region of the ventral tract: The pinfeathers are pale buffy brown, and are tipped with natal down that is being pushed out.

(2) The crural tract: Pinfeathers are whitish with black down at the tips.

(3) The femoral tract: Feathers are approximately the same color as those of the ventral tract.

By the latter part of the fifth week the juvenal plumage of most young rails is developing in all body areas, but feathering of the crown and back of the neck may begin slightly later in some individuals. The abdominal region, axillary region, chin, and upper throat are whitish and contrast rather sharply with the dusky upperparts, particularly the lower back and rump. The dark brown feathers of the upper back and humeral tract are well advanced, feathers of the cervical region (lower throat) are approaching a cinnamon color, and the thighs and flanks are faintly barred. The upper and undertail coverts are making their appearance, and the anal circlet is surrounded by short white feathers.

Quills began to appear the latter part of the fifth week on the wings and tails of two of four captive birds. The primary and secondary coverts developed more rapidly than did the primaries and secondaries. The linings of the wings developed last.

By the sixth week the side of the head is whitish and faintly washed with gray. A white supercilliary stripe is beginning to ap- 


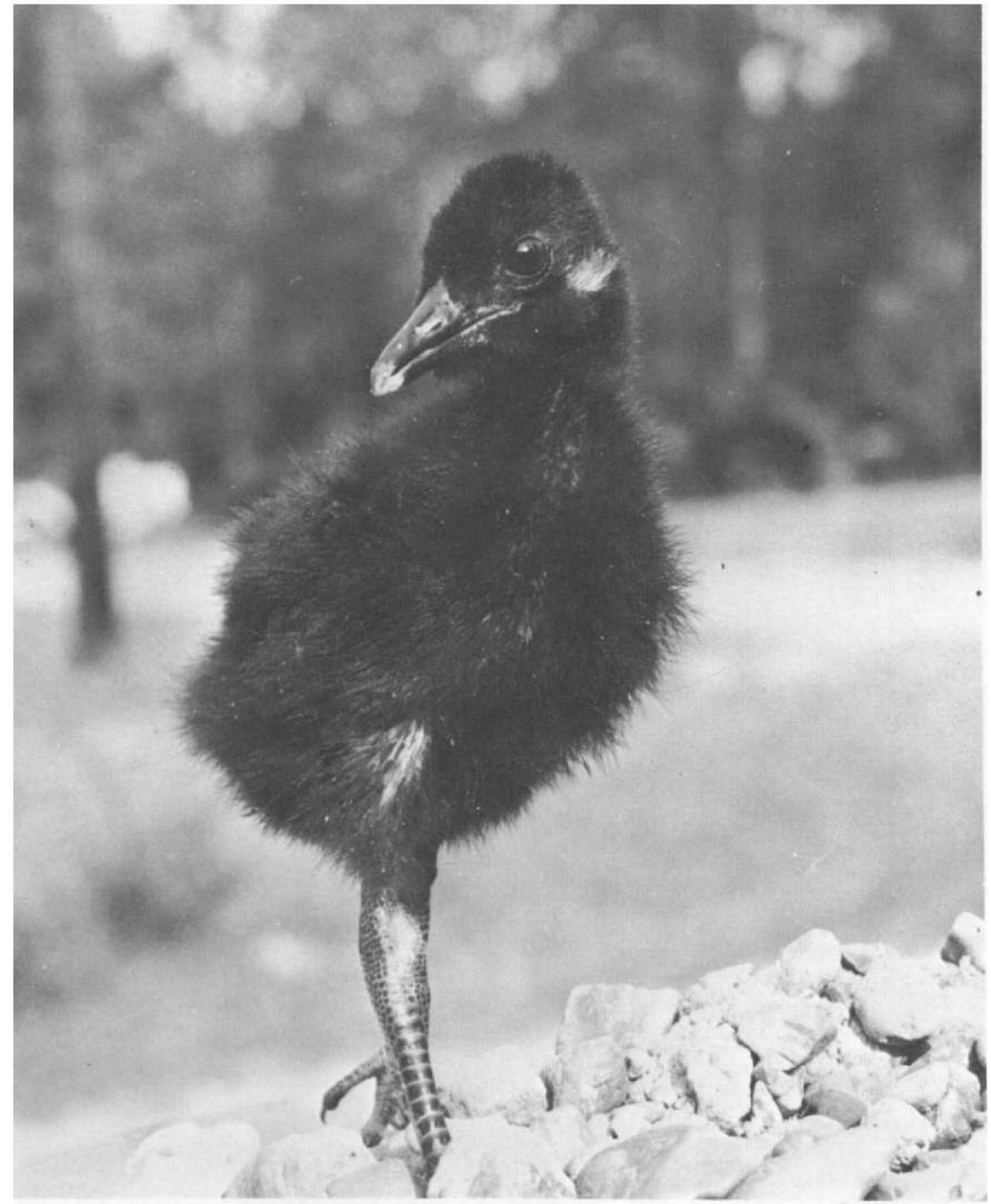

Frgure 27.-Downy young King Rail, 31 days old, with juvenal plumage beginning to develop. White auriculars (of ear region) and white feathers of crural tract are visible; tip of bill and nares are white. 


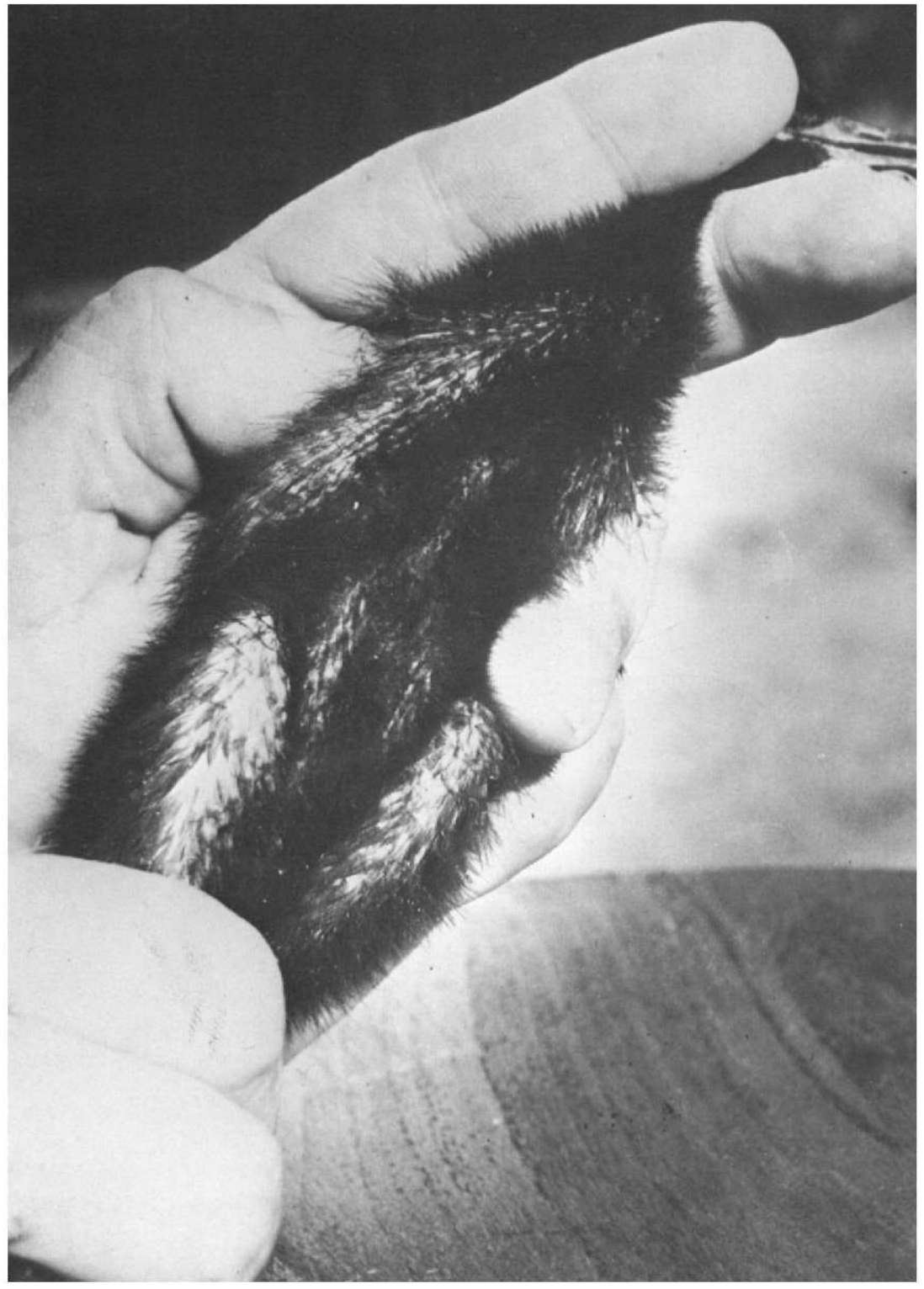

Figure 28.-Ventral view of 31-daj-old King Rail showing development of white juvenal plumage in sternal and abdominal region and crural tract. 


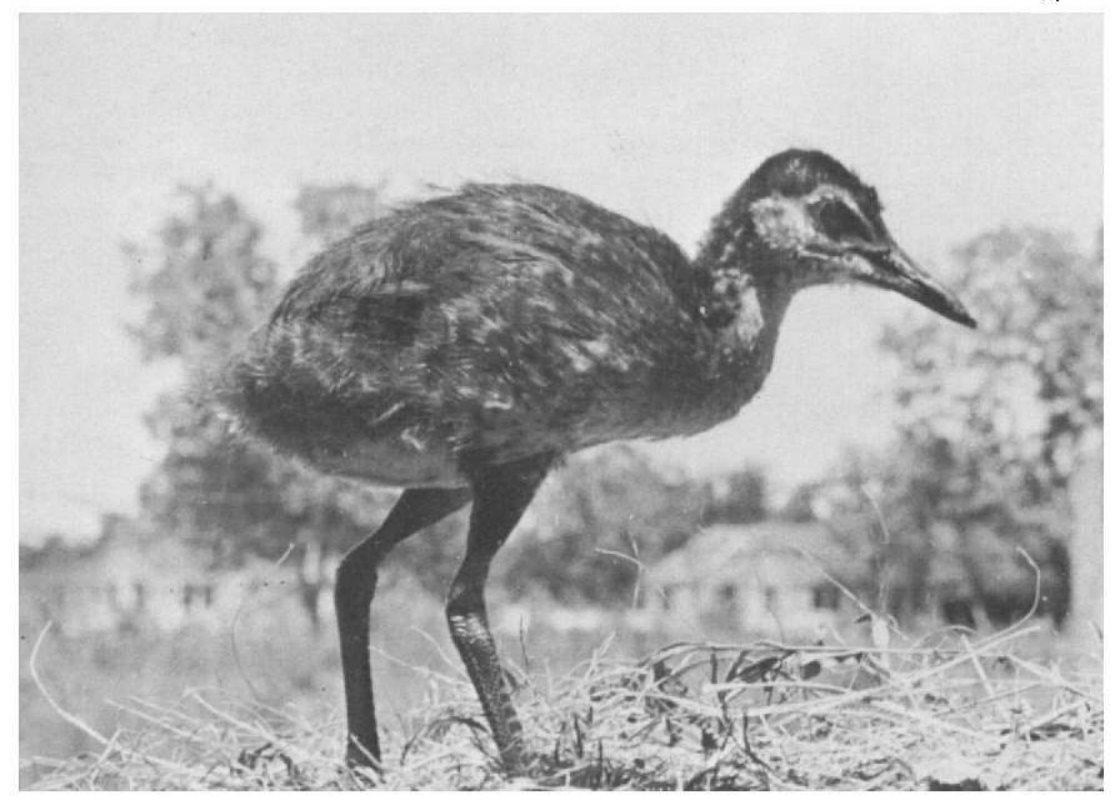

Frgure 29.-Fifty-day-old King Rail with fuvenal plumage nearly complete. Tail and wings are undeveloped. This individual is slightly behind the average for its age.

pear. The legs ar.u bill approach flesh color, and the distal half of the bill is darker than the proximal half. The eyes have brown irides and black pupilis.

By the seventh or eighth week the juvenal body plumage is almost. completed, and the young King Rail has a more brownish and less dusky appearance (fig. 29). The cinnamon coloring of the lower throat and breast approaches that of the adult. The juvenal featherings of the crown and nape are complete, and the flight feathers and tail are well advanced on most birds.

There may be considerable variation in weight and size of young rails during the second month of development. At two months a captive male and two captive females weighed $327.0,258.6$, and 202.0 grams respectively.

The juvenal plumage is nearly complete by the age of 60 days. Remiges have developed enough so that some juveniles can make short flights after the ninth week.

Ridgway and Friedmann (1941, p. 84) have presented a detailed account of the juvenal plumage, as follows:

Above similar to adult, dark phase, but the dark centers of the feathers of the back, etc., less fuscous, more dull black, the edges grayer and less well developed on the interscapulars and not at all developed on the lower back and rump which are uniformly blackish, the long scapulars being the only feathers with well-developed tawny-olive margins; lesser and some of the outer greater 
upper wing coverts tipped with white and crossed by another narrow white band about $7 \mathrm{~mm}$. anterior to the tip; sides of head as in pale phase adult, but the light ochraceous-buff areas cross-barred with narrow dusky lines (actually the tips of the feathers); lower throat pale, light ochraceous-buff narrowly barred with grayish hair brown to deep drab; anterior part of breast more heavily washed with pale ochraceous-buff; rest of breast and entire abdomen white, crossed by broad, closely spaced, but somewhat broken bands of grayish hair brown, the middle of the abdomen and lower breast unbarred; sides and flanks dusky grayish olive-brown barred with white or buffy white; thighs and vent like sides of breast but somewhat darker; under tail coverts and under wing coverts as in adult.

Call notes of young rails remain essentially the same during the second month of life as they were during the first month, but the voice becomes a little hoarser and deeper. During the second month the young rail frequently exercises by jumping up and down, flapping its wings at the same time.

The begging display may still be observed occasionally during the ninth and tenth weeks, but it soon disappears.

A considerable change in calls occurs during the ninth and tenth weeks. Some of them now approximate the calls of the adults. The call most like that of an adult bird is a raucous crying squawk or catlike "meow." This call is made when a bird is separated from the family group or is excited. The typical jupe-jupe-jupe-call of the adult was not heard until the fifth month.

\section{First winter plumage}

For most individuals the first winter plumage is similar to that of the adult. Some individuals, however, have whitish juvenal-like plumage of the underparts and less distinct markings about the face. Most rails in juvenal and first-winter plumage have some white barring on the wing coverts. This is also true of some adults.

\section{MISGELLANEOUS NOTES ON BEHAVIOR OF YOUNG}

\section{Sleeping}

From the time captive birds hatched until they were approximately a month and a half old, the three to six occupying the same cage slept together. Thereafter, as they assumed a somewhat different sleeping posture, they usually slept separately, but sometimes still slept as a group in the same part of the cage.

During the first 2 weeks after hatching, a warm quart-sized bottle of water was placed in the box with the downy young. When sleepy the chicks would huddle around the bottle, but not always in contact with one another. However, if the bottle was removed, the chicks huddled together when sleeping.

When just a few days old, chicks sleep in a prostrate position. They simply flop down on their bellies, usually with one side of their heads 
(cheeks) against the ground. Shortly thereafter, and until they reach the age of $1 \frac{1}{2}$ to 2 months, they assume a sitting posture for sleeping. Older young sleep more in the manner of adults, standing on one or both legs, with the head turned around and the bill tucked beneath the feathers of the back, or with the neck drawn in and the bill pointed down to the ground.

\section{Competition}

Virtually no peck order was exhibited by captive King Rail chicks during the first 2 weeks of life, when they fed together amicably in one area. Thereafter, they competed for food, and after obtaining a morsel from the common feeding site, would run away and ingest it or run around the cage for several minutes before swallowing it.

Because of size variation of individuals older than 2 weeks of age, there was an obvious peck order, but with little antagonism. A smaller or more agile chick often would not hesitate to steal a morsel from a larger competitor.

\section{Bathing}

When bathing, the King Rail assumes a partial squatting position. By an up and down movement of the legs, the body moves in one cadence, then the wings in another, and finally the head, dipping water and flipping it over the back, in still another. The body feathers are extended (somewhat ruffled), the closed wings are loose and moving, and the head is immersed while cocked sideways, presumably for more surface area, and hence functions better as a paddle in flipping water over the body. Water also reaches the plumage through the up and down action of the body and the movements of the wings. The bathing operation usually takes 1 or 2 minutes. A captive bird evicts another from the bathtub by pecking at its feet rather than at some other part of its body.

\section{WINTER BEHAVIOR OF GAPTIVE RAILS}

During extended freezes or when there is a snow cover, water for drinking is obtained by ingesting snow or small chunks of ice. Captive King Rails were observed ingesting snow and ice during periods of heavy snowfall and during freezeups in a cage on Bluegill Pond at the Patuxent Wildlife Research Center, Laurel, Md. One bird was observed as it ingested a chunk of ice 3 inches in length and $1 / 2$ inch in width.

Captive King and Clapper Rails at Bluegill Pond preferred to rest on the ice rather than in a more protected section of the cage provided with a windbreak and a bedding of straw (fig. 30). During alternating periods of freezing and thawing, spherical chunks of ice, up to the size of a baseball, stuck to the tails of the Clapper Rails, and smaller particles stuck to their breasts. Strangely, particles of ice virtually never adhered to any part of the plumage of the King Rails. 


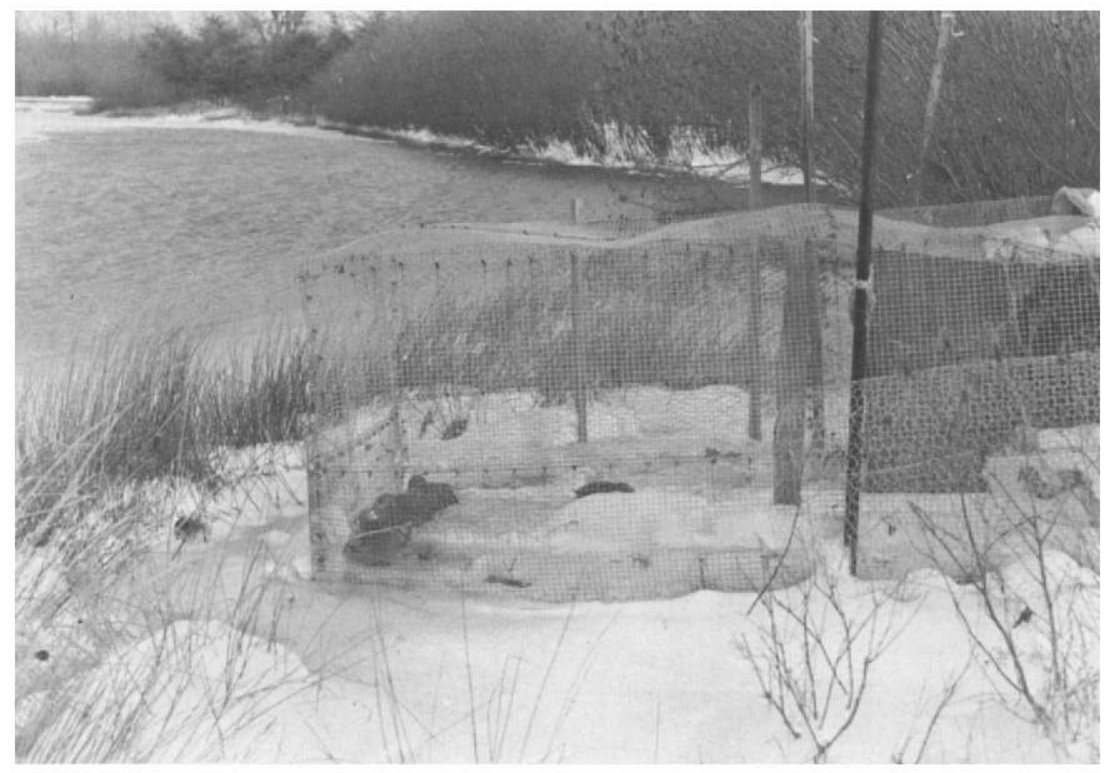

Frgune 30.-Captive King and Clapper Rails at Patuxent Wildife Research Center, Laurel, Md., January 1960. 


\section{Foods}

Crustaceans and aquatic insects are the preferred foods of the King Rail in most areas. Fish, frogs, grasshoppers, crickets, and seeds of aquatic plants also have a high palatability rating with this species. During the winter, particularly when the birds are hard pressed, considerable quantities of grain or some other vegetable matter may be consumed. In the southeastern Arkansas rice country, domestic rice formed 30 percent by volume of the King Rail's winter food. A stomach collected in December at Beaver Dam, Wis., was full of wheat. In South Carolina, Audubon $(1835$, p. 29) examined a gizzard crammed full of oats and collected King Rails in corn fields in autumn near Charleston.

Some unusual foods found in gizzards include cherry (Prunus sp.) seeds, skunk (Mephitis sp.) hair, feathers and vertebrae of a female Red-winged Blackbird, King Rail eggshell fragments, a small water snake (Natrix sp.), a mouse (Peromyscus sp.), a shrew (Sorex sp.), fall army worms (Laphygma frugiperda), blackgum (Nys8a sylvatica) seeds, acorns (Quercus sp.), and pine (Pinus sp.) seeds. A bird collected near Fleming's Landing, Del., on September 30, 1961, had its gizzard crammed with seeds of both waxmyrtle (Myrica cerifera) and bayberry ( $M$. carolinensis).

The King Rail is more diversified in its choice of foods than its salt-water relative, the Clapper Rail, as might be expected because of its wider range and more variable ecology, which may find it feeding on the edge of a salt marsh along the coast or in an oat field a thousand miles inland.

Its adaptability to subsistence on a wide variety of foods in addition to its usual diet of crustaceans and aquatic insects enables the King to winter much further north than is generally realized. A King Rail observed by I. W. Knight at Lorne Park, Ontario, on December 26, 1960, remained in that locality until at least mid-January. It was seen along an open stream where it was observed feeding on a frog and the berries of "deadly" nightshade (Solanaceae) (Woodford and Burton, 1961, p. 326).

In some parts of its breeding range, particularly in brackish tidalriver marshes of the Middle and South Atlantic coast, the King Rail sometimes subsists largely on a 1-item diet, the red-jointed fiddler crab. 
From 1959 to 1961 , several hundred observations were made during the nesting season of King Rails feeding in brackish marshes along the Delaware Bay between Fleming's Landing and Woodland Beach, Del., where the red-jointed fiddler crab occurs in great abundance. This little crab formed the main diet of the rail; the only other item of any importance was a clam (Macoma balthica) (fig. 31). Stomach examinations confirmed field observations.

\section{TaBLE 12.-Principal foods of $118 \mathrm{King}$ Rails from Arkansas ricefields}

[Volume $=$ percent of total volume of stomach contents. Occurrence = percent of stomachs in which found]

\begin{tabular}{|c|c|c|c|c|c|c|c|c|c|}
\hline \multirow{3}{*}{ Food item } & \multicolumn{8}{|c|}{ Collected in $\rightarrow$} & \multirow{3}{*}{$\begin{array}{c}\text { Annusl } \\
\text { volume, } \\
118 \\
\text { stomachs }\end{array}$} \\
\hline & \multicolumn{2}{|c|}{$\begin{array}{c}\text { Winter } \\
\text { (Dec.-Feb.) } \\
\text { 33 stomschs }\end{array}$} & \multicolumn{2}{|c|}{$\begin{array}{c}\text { Spring } \\
\text { (Mar.-May) } \\
\text { 48 stomachs }\end{array}$} & \multicolumn{2}{|c|}{$\begin{array}{l}\text { Summer } \\
\text { (June-Aug.) } \\
\text { 16 stomachs }\end{array}$} & \multicolumn{2}{|c|}{$\begin{array}{c}\text { Fall } \\
\text { (Bept.-Nov.) } \\
21 \text { stomachs }\end{array}$} & \\
\hline & $\begin{array}{l}\text { Vol- } \\
\text { ume }\end{array}$ & $\begin{array}{l}\text { Occur- } \\
\text { rence }\end{array}$ & $\begin{array}{l}\text { Vol- } \\
\text { ume }\end{array}$ & $\begin{array}{l}\text { Occur- } \\
\text { rence }\end{array}$ & $\begin{array}{l}\text { Vol- } \\
\text { ume }\end{array}$ & $\begin{array}{l}\text { Occur- } \\
\text { rence }\end{array}$ & $\begin{array}{l}\text { Vol. } \\
\text { ume }\end{array}$ & $\begin{array}{l}\text { Oecur- } \\
\text { rence }\end{array}$ & \\
\hline \multicolumn{10}{|l|}{$\begin{array}{l}\text { ANmal: } \\
\text { Invertebrate: }\end{array}$} \\
\hline Crayfish. & 7 & 18 & 61 & 81 & 22 & 25 & 3 & 5 & \\
\hline Aquatic beetles. & 20 & 76 & 7 & 21 & 19 & 31 & 10 & 48 & \\
\hline Land beetles..... & 1 & 13 & 8 & 56 & 11 & 87 & 4 & 38 & \\
\hline Grasshoppers......... & 5 & 24 & 3 & 8 & 6 & 63 & 14 & 57 & \\
\hline $\begin{array}{l}\text { Aquatic bugs. } \\
\text { Other insects }\end{array}$ & (1) 5 & 24 & $\frac{1}{2}$ & 15 & $\begin{array}{r}10 \\
8\end{array}$ & 44 & $\begin{array}{l}6 \\
5\end{array}$ & 29 & 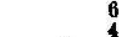 \\
\hline Spiders.............. & (1) & $\begin{array}{r}21 \\
3\end{array}$ & (1) ${ }^{2}$ & 2 & (I) 8 & 13 & i & 10 & (1) \\
\hline Snails - . & 3 & 12 & 2 & 8 & (1) & 6 & (1) & 10 & \\
\hline Vertebrate: & & & & & & & & & \\
\hline Fish_.... & 7 & 30 & 1 & 21 & 8 & 19 & 26 & 43 & 11 \\
\hline Frogs, & 5 & 21 & 4 & 15 & 5 & 50 & 4 & 24 & \\
\hline Miscellaneous & 3 & 7 & 6 & & & & & & \\
\hline \multirow{4}{*}{ PLANT: Total } & 58 & $\ldots$ & 95 & ..... & 90 & - & 74 & $\cdots$ & 79 \\
\hline & & & & & & & & & \\
\hline & $(1)^{30}$ & 36 & (1) ${ }^{4}$ & $\begin{array}{r}19 \\
4\end{array}$ & $(1)^{10}$ & $\begin{array}{l}31 \\
56\end{array}$ & $\begin{array}{r}21 \\
2\end{array}$ & $\begin{array}{l}29 \\
38\end{array}$ & 1 \\
\hline & 12 & 21. & & & .... & & 3 & 10 & 1 \\
\hline Total ... & 42 & ....... & 5 & & 10 & & 26 & & 2. \\
\hline
\end{tabular}

1 Trace.

There is considerable variation in food items taken by different individuals in the same habitat and at the same time. Two birds collected from a tidal marsh on the Choptank River in Maryland in February 1961 present an interesting contrast. Bird A fed entirely on fish, while bird B ate a wide and rather unusual assortment of foods including the seeds of arrow-arum, hackberry (Celtis occidentalis), halberd-leaved tearthumb (Polygonum arifolium), dogwood (Cornus florida), and grape (Vitis sp.). Bird B had also eaten crayfish and a snail (Gastropoda). The seeds of arrow-arum contain calcium oxalate crystals and apparently are rejected by virtually all water birds except the Wood Duck (Aix sponsa). This was the only time $\mathrm{I}$ encountered them during my studies of rail foods.

Only in the Arkansas ricefields has a fairly complete seasonal survey of King Rail foods been made (Meanley, 1956, p. 252-258). 


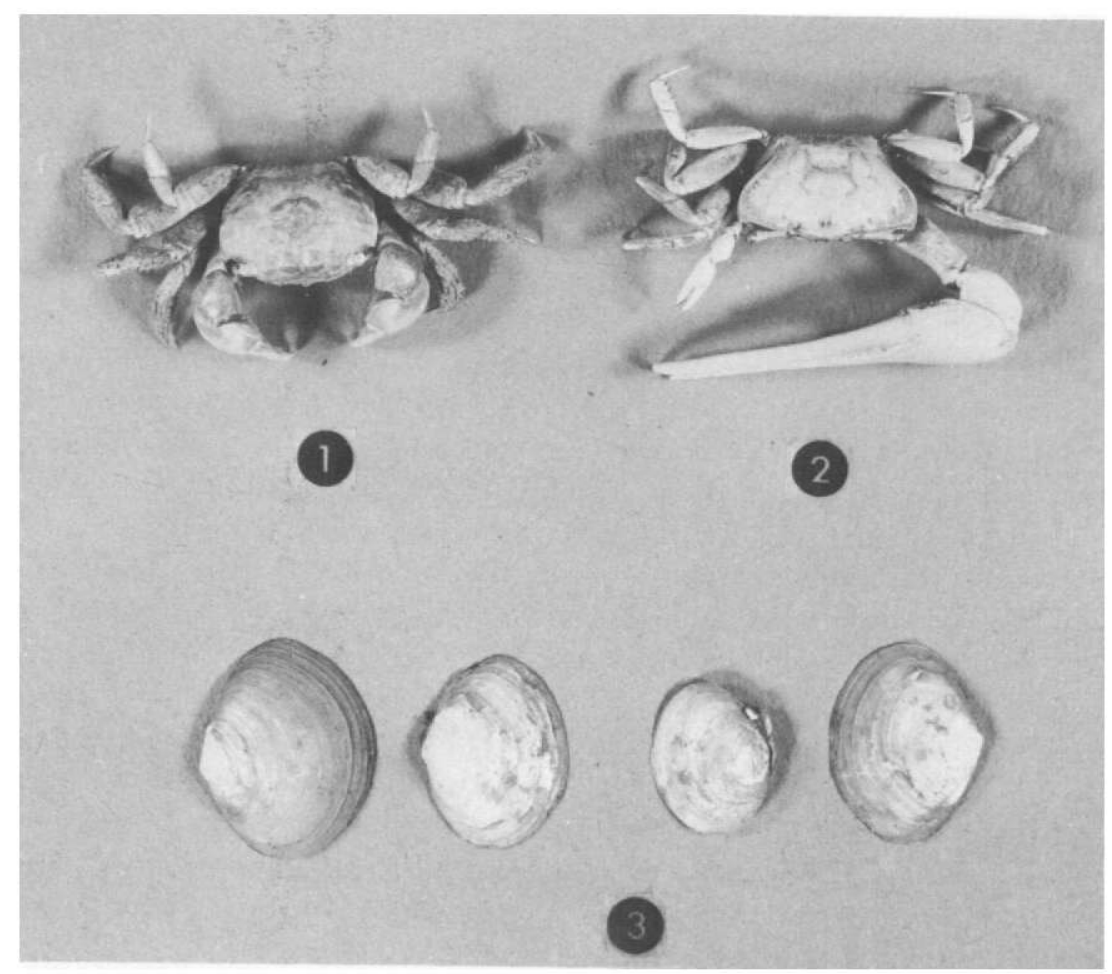

FToure 31.-Foods of the King Rail in brackish bay marsh, Broadway Meadows, Kent County, Del.: (1) Mud crab (Sesarma reticulatum); (2) red-jointed flddler crab (Uca minax); (3) clam (Macoma balthica). (Photograph by Frederick C. Schmid.)

Small series of stomachs have been collected from a few other localities. Most of these were examined by John C. Jones of the U.S. Fish and Wildlife Service.

\section{ARKANSAS RICEFIELDS}

In the Grand Prairie rice-producing area near Stuttgart, Ark., 118 stomachs were collected between 1950 and 1955 by Karl Kitler and myself (table 12).

Animal life comprised 79 percent of the King Rail's annual diet. It constituted 90 percent or more in spring and summer, dropped to 74 percent in the fall (the largest number of stomachs were collected in November and may have made the figure lower than if there had been better representation of the early part of this season), and was still lower ( 58 percent) in winter.

The shift in feeding grounds from roadside ditches in the spring to ricefields in summer and early fall, and finally back to natural drainage ditches and small cattail marshes in winter, may account for 
some of the seasonal variations in diet. However, seasonal fluctuation in the abundance of aquatic animal life is apparently the basic explanation.

The crayfish was the principal food of the King Rail in the rice area, constituting 23 percent (by volume) of the annual diet; it formed 61 percent in spring; 22 percent in summer; 3 percent in fall; and 7 percent in winter. Since crayfish were available the year round, it appears that consumption of this crustacean was influenced as much by the availability of other favored foods as by the abundance of crayfish. Possible seasonal variations in the size, agility, and/or palatability of the crayfish according to age may have been factors bearing upon the extent of seasonal use by the King Rail.

Another staple food available at all seasons was fish, which composed 26 percent (by volume) of the diet in the fall when many fish had become impounded in the shallow borrow pits of drained ricefields and were easy prey for the foraging birds.

Aquatic insects were important foods, especially certain beetles and waterbugs which were available the year round. Predaceous diving beetles (Dytiscidae) furnished 19 percent of the winter diet.

Land beetles, chiefly ground beetles (Carabidae), scarabs (Scarabaeidae), and snout beetles (Curculionidae) made up 6 percent of the rail's annual food, while grasshoppers (Orthoptera) constituted 7 percent.

A wide variety of other insects were taken in small quantities. During the summer and fall they formed 8 percent and 5 percent, respectively, of the food. Among these insects were dragonfly (Odonata) nymphs, back-swimmers (Notonectidae), horsefly (Tabanidae) larvae, fall army worms, rice water weevils (Lissorhoptrus simplex), and rice stinkbugs (Solubea pugnax).

Frogs accounted for about 5 percent of the annual diet.

The King Rail apparently is more of a vegetarian than its salt marsh counterpart, the Clapper Rail. John Oney $(1954$, p. 23), in studying fall foods of the Clapper Rail along the Georgia coast, found that plant materials constituted only trace items of the Clapper Rail's diet at that season. Martin, Zim, and Nelson (1951, p. 82) found the volume of plant food in the Clapper Rail's diet to be 11 percent in winter, 1 percent in spring, 0 percent in summer, and 3 percent in fall. In the Arkansas area, vegetable matter in the diet of the King Rail made up the following volumetric percentages during the 4 seasons: 42 percent in winter, 5 percent in spring, 10 percent in summer, and 26 percent in fall.

Cultivated rice seed was taken in larger quantities than any other plant food, forming 16 percent of the annual diet. Increased consumption of rice seed during fall and winter was due in part to the abundance of waste grain left in the stubble. Kalmbach (1937, p. 60), 
in his study of the food of blackbirds in Louisiana, suggested that the hard siliceous hulls of rice seed may be used in the gizzard for grinding.

Ricefield weeds, abundant in all rail habitats, furnished some food through the year. Seeds of jungle-rice (Echinochloa colonum), wild millet, bullgrass, rice-cutgrass, beakrush, and smartweed (Polygonum spp.) were found as traces in many stomachs in each season except fall when they composed 2 percent of the contents.

The following seeds of woody plants were found in several stomachs: blackberry (Rubus sp.), snowball (Styrax americana), blackgum, and oak. Tubers of marsh plants, probably sedge (Cyperaceae), were found in several stomachs, and one rail had eaten tubers of an arrowhead.

\section{TEXAS RICEFIELDS}

Twelve stomachs were collected in ricefields at Eagle Lake, Colorado County, Tex., during September 1938 by Valgene W. Lehmann.

Three items formed the bulk ( 63 percent) of the food and occurred in at least half of the stomachs. The most important, the coneheaded grasshopper (Neoconocephalus sp.), occurred in nine stomachs and formed 30 percent by volume; dragonflies (Odonata) formed 20 percent by volume; and crayfish formed 13 percent by volume. An assortment of insects accounted for most of the remainder. Rice seed was the only plant food taken and comprised only 5 percent of the total food consumed.

\section{LOUISIANA RICEFIELDS}

Nine stomachs were collected in ricefields in the gulf coast region of Cameron and Vermilion Parishes in the summer of 1925 by E. R. Kalmbach and in 1955 and 1965 by myself.

Crayfish were in seven of nine stomachs and were the major item in six. Crickets (Gryllus sp.) were found in four stomachs and were the most important items in three of those. Weevils were the only other important food.

\section{UPPER ST. JOHNS RIVER, FLA.}

Six stomachs were collected in marshes in the Persimmon Hammock area during the spring of 1905 by W. W. Worthington.

Crayfish were the major items in five of the six stomachs. Shorthorned grasshoppers (Acrididae) occurred in all of the stomachs, but were important percentagewise in only one. Aquatic and land beetles formed the balance of the food.

\section{CURRITUGK SOUND, N.C.}

Seventeen stomachs were collected, mostly in October, November, and December, 1909 and 1910, at Church's Island by J. B. White and W. L. MaAtee. 
Animal life formed 88 percent of the food with seeds of aquatic plants forming most of the balance. Important animal foods were sunfish (Centrarchidae) and perch (Percidae), grasshoppers and locusts, and aquatic insects (mostly Belostomatidae, Hydrophilidae, and Haliplidae).

\section{PATUXENT RIVER, MD.}

Six stomachs were collected in fresh tidal-river marshes along the Patuxent River in southern Maryland in early fall between 1923 and 1958 , by O. J. Tremis, C. H. M. Barrett, and unknown rail bird hunters.

An interesting assortment of materials was found in this small series, including killifish (Fundulus heteroclitus), crayfish, dragonfly nymphs, snails (Amnicola sp.), grasshoppers, and crickets; leaves of a bulrush (Scirpus sp.) and rice-cutgrass; seeds of dotted smartweed, halberd-leaved tearthumb, arrow-leaved tearthumb (Polygonum sagittatum), burreed (Sparganium eurycarpum), water parsnip (Sium suave), silky dogwood (Cornus amomum), and wild cherry.

\section{BEAVER DAM, WIS.}

Eleven stomachs were collected in various marsh types during summer and fall, 1889-1908, by W. D. Snyder and C. F. Zimmerman.

Crayfish constituted over 90 percent by volume of the food in 6 stomachs and occurred in 9 of 11. Snails, soldier flies (Odontomyia sp.), dragonfly larvae, a mollusk (Stagnicola palustris), grasshoppers, and a fish (Etheostominae) were major items in the other four stomachs.

\section{GHIGAGO, ILL.}

Five stomachs were collected during spring (April-May), 1912-17, by G. Eifrig and K. W. Kahmann. Crayfish were the major items ( 50 percent plus by volume) in four of the stomachs, and dragonfly nymphs were the major items ( 55 percent by volume) in the fifth. Stalks of a bulrush (Scirpus sp.) were important ( 40 percent by volume) in one stomach, and horsefly larvae were common (42 percent by volume) in another.

Two stomachs were collected during the summers (July) of 1878 and 1915 by S. A. Forbes and K. W. Kahmann. Frogs ( Rana sp.) were the most important food ( 54 percent by volume) in one, and larvae of soldier flies ( 94 percent by volume) in the other.

Crayfish were a major item ( 45 percent plus by volume) in each of the three stomachs collected in the fall (September-October), one in 1913 and two in 1915 by K. W. Kahmann. Frogs (Rana sp.) were important ( 51 percent by volume) in one stomach. 


\section{Feeding Behavior}

King Rails usually feed in areas concealed by plant cover or in comparatively open areas where they blend well with their surroundings and are only a few steps from cover. Sometimes, however, they are very conspicuous, as when feeding at low tide on mud flats or in open roadside ditches. Dawson (1903, p. 443) observed such feeding activity in Ohio:

In a region where they were in little fear of molestation, I have seen them deploy upon an extensive mud flat in broad daylight and go prodding about in company with migrant sandpipers, for the worms which riddle the ooze with their burrows.

In tidewater areas, feeding probably occurs most frequently at low tide. Whenever I visit the brackish marshes of the Delaware Bay at ebb tide, I see King and Clapper Rails feeding in the tidal creek beds.

I suspect that King Rails do very little feeding at night, although they are sometimes active during this period, as they are occasionally heard calling, particularly during the courtship period. King Rails that $I$ kept in captivity in Louisiana and Maryland were relatively inactive at night. In fact, some of them would habitually return to a favorite spot in the cage each evening at dusk, sit down, and remain quiet for long periods.

Generally King Rails forage in water so shallow that only the bill, or part of it, disappears beneath the surface while food is sought. However, on March 25, 1954, on the Arkansas Grand Prairie, I observed a pair of rails feeding in a roadside ditch where the water varied from 6 to 12 inches in depth. Both of these birds immersed their entire heads and necks in water, and several times their entire bodies disappeared beneath the, surface. In fact, they occasionally fed by "tipping up" like dabbling ducks.

Since King Rails are accustomed to procuring their food from the water, if perchance they obtain a food item from land and are near an aquatic environment they usually carry the morsel to the water and immerse it before ingestion.

\section{PELLET GASTING}

Both the King Rail and the Clapper Rail, whose major food is crustaceans, reject most of the exoskeletal fragments of these animals through the regurgitation of pellets (fig. 32).

King Rail pellets examined in Arkansas and Maryland were composed of crayfish and aquatic insect fragments. Nearly every pellet 


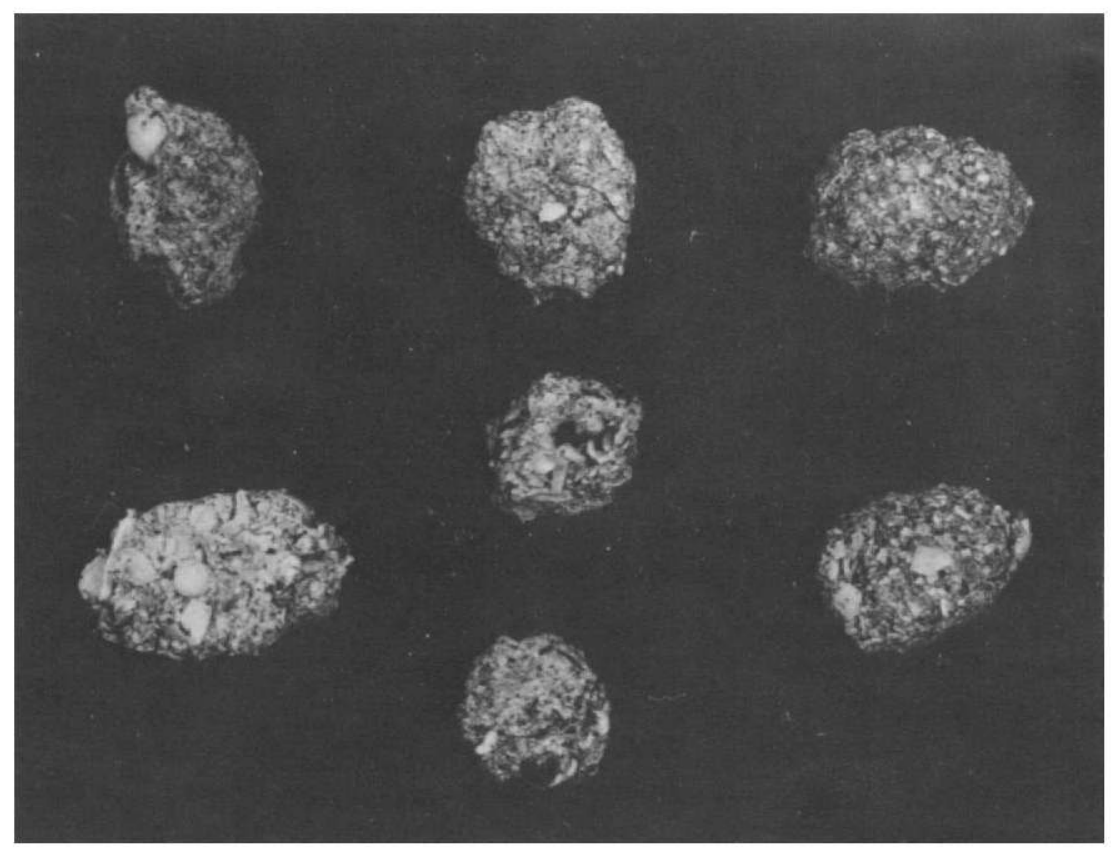

Froukex 32.-Regurgitated King Rail pellets from Dorchester County, Md. Note the round gastroliths of the crayfsh (Cambarus $\mathrm{sp}$.) in top and bottom pellets at left. Pellets averaged $2 \mathrm{~cm}$. in length by $1.5 \mathrm{~cm}$. In width. (Photograph by Frederick C. Schmid.)

examined contained the hard cylindrical convex-shaped gastroliths of crayfish.

In brackish marshes near Woodland Beach, Del., where King and Clapper Rails occur together, pellets contained exoskeletal fragments of the red-jointed fiddler crab and a clam (Macoma balthica). As many as 14 pellets were found on a single muskrat house.

\section{FEEDING YOUNG}

I have observed King Rails feeding their chicks within 2 hours after hatching. Gross and Van Tyne $(1929$, p. 439) reported the same for the Purple Gallinule, another member of the family Rallidae.

When the very small young are abroad, they follow one or both parents about as food is caught for them. Larger food items such as crayfish and large grasshoppers are dismembered and fed to the young in pieces.

Sometimes, however, the young remain in a concealed place and wait for the parent to bring them food. At Grand Chenier, La., April 8, 1956, I observed a pair of adult rails for over an hour as they kept up a steady pace to and from a small pond catching fish and carrying them to young hidden behind tussocks of grass 30 or so feet distant. 
Similar feeding was observed in a Louisiana ricefield where adults brought crayfish to young that remained in the same spot.

As the young grow older, they not only accept food from their parents but also begin to forage for themselves. An interesting example of this dual feeding activity was observed near Woodland Beach, Del., on July 29 and 30, 1959. An adult King Rail and three young approximately 5 to 6 weeks of age were observed feeding on clams at low tide in the bed of a creek. The adult bird dug in the mud for the clams, usually inserting its entire head beneath the surface. It would eat four or five clams and then carry one to the young. The clams were swallowed whole. Sometimes one of the young, standing next to its parent, would watch the digging operation and then start digging for itself. The parent and its young were seen digging for clams in the same place on both days. A raccoon also came to this spot and dug many clams.

\section{REGIONAL OBSERVATIONS}

\section{Arkansas ricefields}

During March, April, and May 1952 it was not unusual to see 15 or 20 King Rails in the evening feeding along ditches bordering certain highways leading out of Stuttgart, Ark. The variety of rail food available in these roadside ditches includes crayfish, tadpoles, frogs, aquatic insects, small fish, and snails. Toward the end of May the rails move out of the ditches and into ricefields, where they are found until harvest. During the winter they are found about the network of ricefield canals and natural drainage, often moving from place to place along runways beneath matted vegetation.

The King Rail feeds almost exclusively in ricefields during the summer. About the only time it emerges from this cultivated marsh type is to move from one ricefield to another. When a field of nearly mature grain is drained preparatory to harvesting, the rails move over to a field of younger rice which is often contiguous to the dry field. Some ricefields have a few low wet spots which prove attractive to rails, even up to harvest time; but the last feeding place in nearly all drying ricefields is along the "borrow" or ditch bordering the levees.

This typical bird of the rice country performs a service to the rice grower by consuming large numbers of crayfish that bore holes in the ricefield levees. A single large crustacean is usually torn apart and eaten in the course of several minutes; in one case the dismembering operation was timed at 7 minutes. Small crayfish are ingested whole.

\section{Delaware Bay marshes}

In the brackish tidal marshes between Fleming's Landing and Woodland Beach, Del., I have found King and Clapper Rails feeding 
in the same tidal gut. An important food of the rails here is the redjointed fiddler crab, which is found further upstream than other species of fiddler crabs, but not far above the brackish zone and, as far as I know, not beyond tidewater in this area.

In some areas, fiddlers' holes or dens are concentrated mostly along or just beneath the top of the embankment of a tidal gut, and at high tide are inundated. Rails seem to feed mostly at low tide. When stalking fiddlers, rails are very slow and deliberate. When within striking distance, a rail makes a quick thrust or stab at the crab. When a fiddler is caught, it is often taken to some favorite feeding spot, such as a muskrat house or pile of drift debris, for dismembering. The large claw of the male crab is disengaged in the following manner, as described by Oney (1954, p. 24-25) for the Clapper Rail:

The bird grasps the crab with its bill between the claw and the body. Then holding the crab, it vigorously shakes its head. The claw goes one way and the crab another. The bird then runs over and picks up the body and swallows it. The female crab does not get the same treatment because both of their claws are nearly equal size.

Some fiddlers, too large to swallow, are hacked to pieces and then eaten bit by bit.

\section{Savannah National Wildlife Refuge}

In early April 1960, I made observations of feeding King Rails along an alligatorweed-choked canal on the Savannah National Wildlife Refuge. Alligatorweed forms extensive mats upon which rails, gallinules, coots, herons, and several species of ducks do much of their foraging for aquatic insects, fish, tadpoles, frogs, and crustaceans. While this vegetation type has no apparent value in a waterfowl management program, it is of obvious value to birds that utilize its growth form to facilitate food gathering. Some King Rail feeding territories along the alligatorweed-choked canal were no more than 20 feet square, indicating the high rail-food productivity of these aquatic mats.

The most frequently observed pair of rails defended their feeding territory vigorously. Although they nested on the other side of the dike some 40 yards distant in a sawgrass marsh, they consistently returned to the same section of the canal for feeding.

The base of operations in the pair's feeding territory was a pile of debris, possibly an old alligator nest, at the edge of a small clump of giant cutgrass. From here the rails radiated out to feed on the mat of alligatorweed. Whenever a crayfish or some other large morsel was obtained, it was brought back to the pile of debris for "servicing" and eating. Old earthen dikes still much in evidence throughout the abandoned ricefield marshes of the Carolina Low Country are also used for this purpose. 
Along the low banks of the canals, and sometimes partially submerged in the alligatorweed, numerous alligators, some 5 to 6 feet in length, sun themselves on warm spring days (fig. 14). They lie motionless for several hours at a time, and if they move there is simply a splash and complete submergence. It would seem that, to a waterbird wading around in the canal, an alligator sunning along the water's edge would look like another one of the many logs lying half submerged in the alligatorweed. But this is not the case. Rails, gallinules, and other birds feeding in the canal recognize the alligator as an enemy and usually give it a wide berth. Sometimes, however, they feed to within 2 feet of an alligator before circling the animal or retreating.

\section{SOME UNUSUAL OBSERVATIONS}

A very unusual feeding performance was recorded by Earle McPeak (Trautman, 1940, p. 230) at Buckeye Lake, Ohio. On June 11, 1929, an adult King Rail was observed to uncover, break, and eat five eggs of a painted turtle (Chrysemys picta), which on the preceding day McPeak had watched the turtle lay in a hole and cover with earth.

Another unusual field observation concerned the capture and devouring of a Semipalmated Sandpiper (Ereunetes pusillus) by a King Rail. E. D. Greaves (Chamberlain, 1960, p. 443) reported this incident, which took place at Pea Island, N.C., May 22, 1960:

The rail darted out of the grass, picked the sandpiper from a feeding flock and after stabbing it repeatedly, pulled it apart and devoured it.

In June 1960, at low tide in Taylor's Gut, Kent County, Del., I saw a King Rail pursue and peck at a 3-foot-long water snake (Natrix sp.) for a distance of some 50 feet. Finally, the snake stopped and remained motionless for about 2 minutes as the rail continued to peck at it. Eventually each took off in a different direction. Possibly the rail was chasing the snake out of its nesting territory rather than pursuing it for food.

At Grand Chenier, La., March 1956, I observed a rail catch a crab in an open spot in the marsh. As the rail headed for cover to feed on the morsel, it was harassed so much by a Boat-tailed Grackle (Cassidix mexicanas) that it surrendered the crab to the blackbird.

Nauman (1927, p. 218) reported the following unusual feeding activity which took place at his home in Iowa during a snow storm. On April 16, 1921, when there were 8 inches of snow on the ground, a King Rail was observed walking around on the porch picking up bread crumbs. Until the snow melted, it returned to the porch on numerous occasions to feed on crumbs.

At the Paturent Wildlife Research Center, a captive 10-month-old female King Rail attempted to eat a mouse and choked to death. 


\section{Mortality Factors}

The most important factors in mortality of King Rails are (1) striking (or being struck by) manmade objects and (2) predation. In recent years, pesticides may also have become an important factor. From time to time, hurricane-caused floods decimate coastal marsh populations.

\section{MANMADE OBJECTS}

Since King Rails are nocturnal migrants, they strike various illuminated objects such as television towers, ceilometers, tall buildings, and lighthouses. On their breeding grounds in the southern rice belt, I have found dead King Rails under telephone lines and impaled on barbed wire fences.

The automobile is an increasing hazard because of the network of roads in the intensively cultivated rice country and the marshland of the South Central States. Over a 3-month period (March 1-June 1, 1952), I found 24 dead adult King Rails along a 10-mile stretch of paved road leading north from Stuttgart, Ark.

During floods in the gulf coast marsh country of Louisiana, King Rails and other water birds are literally flushed out of the marshes to the nearest high ground, which is often a well-traveled highway. During one period of high water in the marsh bordering the highway between the Intracoastal Canal and Creole, La., I saw 30 King Rails (mostly adults with broods) walking back and forth across the road in the face of heavy traffic. Many were being killed, particularly the young.

Wherever muskrats are trapped, King, Virginia, and Sora Rails become casualties since they use the runways where the traps are placed. Whenever I have encountered muskrat trappers in the course of my travels from New Jersey to Louisiana, I either have seen King Rails removed from traps or have been told of the many that are caught incidental to muskrat trapping. One trapper encountered in Maryland caught 50 King Rails during the course of a single trapping season (21/2 months).

\section{PREDATION}

Judging from the many examples of predation in the literature, the King Rail appears to have a wide variety of natural enemies. Fur bearers are probably the most important, chiefly the raccoon, because of its fondness for eggs, and its abundance in most marsh habitats. 
At a Lonoke, Ark., fish hatchery two rail nests found along the edge of a pond had been broken up by raccoons as evidenced by numerous tracks leading from the nest to a point in the open where the eggs had been taken and destroyed.

The mink may also be an important predator of this rail. The Rev. John Bachman, pioneer naturalist from Charleston, S.C., was quoted by Audubon (1835, p. 29-30) regarding the fate of the King Rail as follows:

Its feathers are frequently found lying on the banks of rice-flelds, ponds and lagoons, in places where the tracks of the minx plainly disclose the plunderer.

Similarly, on the Arkansas Grand Prairie, a mink trapper told me of finding typical mink signs at freshly killed King Rails. In Currituck County, N.C., Kenneth Wilson (1954, p. 199-307) found six species of birds taken by mink, including the King Rail. Wilson also cited one case in which an otter (Lutra canadensis) ate one of these large rails.

Predation by a bobcat (Lynx mufus) was noted by Bachman and cited in Audubon (1835, p. 29-30) as follows:

... while placed on a stand for deer, I saw a wildcat creeping through a marsh that was near to me, evidently following by stealthy steps something that he was desirous of making his prey. Presently he made a sudden pounce into a bunch of grass, when I immediately heard the piercing cries of the Marsh-Hen, and shortly after came passing by me the successful murderer with the bird in his mouth.

Tanner and Hendrickson (1956, p. 56) found a dead King Rail at the den of a red fox ( $V$ ulpes fulva) in Iowa:

During May and June 1951, the den of a red fox on the rearch area was visited almost dally and the remains of prey brought to the den by the parent fox examined. The only rail seen at the den was an adult King Rail found May 12. Since this bird had not been present May 11, and obviously had been dead several days, it seemed likely that it had been found dead by the foxes and brought to the den as carrion. The carcass had not been mutilated.

Bachman (in Audubon, 1835, p. 29) also found remains of a King Rail in the stomach of a large moccasin (probably Agkistrodon piscivorus). Another ornithologist of the Charleston area, Arthur T. Wayne, also cited an example of cottonmouth predation on the King Rail (1910, p. 36) :

In the month of April, 1900, I was observing a nest of this species in a buttonwood bush, which was in a pond of water, and, about every other day, I waded into the pond to see how many eggs were there. About the 8th of May, I judged that the full complement of eggs would be completed, and upon visiting the nest in the afternoon, which was very cloudy, I saw what I supposed to be the bird incubating. But upon close inspection I was very much surprised to find that what I took for the bird was a huge Moccasin (Ancistrodon piscivorus), which I promptly shot. This snake had eaten all the eggs and perhaps caught the bird as the feathers were scattered around the nest. 
John W. Aldrich (personal communication) collected a fox snake (Elaphe vulpina) that had several King Rail eggs in its digestive tract, in Little Cedar Point Marsh on Lake Erie in Ohio.

Alligators (Alligator mississipiensis) are known to take King Rails. Kellogg $(1929$, p. 32) found remains of King Rails in 4 of 15 stomachs of alligators taken in Cameron Parish, La., in 1926.

Coulter $(1957$, p. 18) examined the gastrointestinal tracts of 157 common snapping turtles (Chelydra serpentina) from Maine marshes and found bird remains in about one of every four.

Forty-two specimens contained evidence of a minimum of 52 birds including 25 ducks, 11 grebes, 3 rails and 13 unidentifled birds.

No mention is made of the rail species taken. Birds the size of a King Rail could easily be taken by a large snapper. As an example, one 31-pound turtle consumed five birds including one Ring-necked duck (Aythya collaris), one Common Golden-eye (Bucephala clangula), and three Pied-billed Grebes (Podilymbus podiceps).

Hawks and owls take their toll of rails, gallinules, and coots. This is to be expected since virtually all birds of prey hunt in marshes as well as in uplands. Errington and Breckenridge (1936, p. 835) found the remains of a King Rail in a Marsh Hawk (Circus oyaneus) collected in August 1934 in the North Central States prairie region. Errington (1932, p. 182) also found remains of a King Rail in a Great Horned Owl (Bubo virginianus) pellet collected in April 1930 in southern Wisconsin.

The Fish Crow (Comvus ossifragus), well known as a plunderer of Clapper Rail eggs, is also known to take eggs of other rails. Frank C. Kirkwood and John Sommer found broken King Rail, Virginia Rail, and Least Bittern egg shells beneath an active Fish Crow nest at Gum Swamp Island, Blackwater Marsh, Dorchester County, Md., on June 16, 1929 (from Kirkwood's field notes, 1929).

\section{HURRICANES}

An interesting account of King and Clapper Raii behavior during a hurricane in the Louisiana prairie marsh country was given by Robert J. Newman (1957, p. 409), from information based on eye witness accounts of $\mathrm{H}$. W. Belknap, graduate student from Louisiana State University, and J. H. Sutherlin, Manager of Sabine National Wildlife Refuge. Hurricane Audrey was Louisiana's worst coastal storm of the present century and struck with its greatest force along the southwest Louisiana coast on the morning of June 27, 1957. Newman's report was as follows:

Rafts of marsh debris, ranging in size from $10 \times 10$ to $20 \times 100$ feet, went floating by (HWB, JHS). On them huddled a strange company of water moccasins, nutria, rails, and gallinules-sometimes as many as 20 birds to a raft. Occaslonally as the great rollers surged forward, the mats of vegetation would buckle 
and disintegrate. Then, according to Sutherlin, the Purple Gallinules would drown, but the supposedly less aquatic Clapper or King Rails would swim adeptly away through the rough water and flying spindrift.

The rain-drenched lawn at Sabine headquarters became a sanctuary within a sanctuary. The wildlife congregated there included water snakes, a marsh deer, a skunk, armadillos, and 200 to $250 \mathrm{King}$ or Clapper Rails. 


\section{The King Rail as a Game Bird}

Although a prized game bird, this large rail is seldom hunted because of the difficulty of maneuvering in its habitat, and the unlikelihood of finding concentrated numbers. Hence there are few localities where the King Rail can be considered an important game bird. In the gulf coast domestic rice producing areas of Texas and Louisiana, where King Rails are most numerous, they are probably shot in greater numbers than anywhere else; however, here considerably less than 1 percent of the local population is shot. In the Middle Atlantic States, the largest numbers are taken by hunters shooting Sora in the wildrice marshes of the Delaware Valley and Chesapeake Bay. However, in this area, some hunters will gun the wildrice marshes all season without seeing a King. Elsewhere in its range, the King Rail is shot only incidentally. Quail hunters in the South frequently encounter them and take a few.

Probably the best known hunting grounds in the Delaware Valley are in the wildrice marshes of Salem and Cumberland Counties, N.J. The tidal marshes of the Maurice and Cohansey Rivers in Cumberland County are famous rail hunting areas. The Patuxent River marshes near Upper Marlboro are the most important areas in the Maryland part of Chesapeake Bay; while in Virginia Tidewater, King Rails are hunted mostly along the lower James River in the upper reaches of some of its tributaries such as the Chickahominy; and along the Pamunkey and Mattaponi, famous Sora shooting rivers which downstream form the York. One of the most popular spots for King Rail shooting in Texas ricefields is the Eagle Lake area in Colorado County.

A few King Rails are killed by Clapper Rail hunters in coastal salt marshes. Hunters Tom Reed and Gordon Clark killed 3 Kings and 50 Clappers in 2 days of gunning at Chincoteague, Va., during September 1961.

In the open piney woods of Central louisiana it seems odd to see a King Rail during the winter in some wet spot in the bluestem range. I know of several hunters in that locale who take one or two in each quail and woodcock season.

\section{METHODS OF HUNTING}

Contrary to popular opinion, the King Rail is not always an easy mark for the hunter despite its alleged weak flight. Characteristics 
of its habitat and other circumstances govern the manner in which it flies, and I have seen several fly at a fast clip for 300 yards.

The Marsh Hen, as this bird is sometimes called, tends to be secretive, but at times it is found in completely open situations near cover. It is not readily flushed, usually escapes by running, and flies only as a last resort. Flight begins with the legs dangling, but as the bird levels off, it flies in a straight line close to the ground with its legs extended straight back beyond the tail and its neck stretched forward.

Methods of hunting King Rails in the wildrice marshes of Chesapeake Bay and the Delaware Valley are quite different from those in the domestic ricefields of Louisiana and Texas. In the Chesapeake Bay and Delaware River tidal marshes, rails are hunted mostly from long, narrow, flat-bottom boats that are poled through the flooded wildrice beds by a "pusher" (figs. 33 and 34). When tides reach peak level, the rails flush as the boat approaches them.

\section{Patuxent River, Md.}

On the Patuxent River in the Southern Maryland tobacco country, rail hunting has been a sport enjoyed by the tobacco growing aristocracy since Colonial times. Perc Blogg (1944, p. 67-68), famous Maryland sportsman of the "good old days," presents an account of the hunting of Soras and King Rails on the Patuxent in his delightful

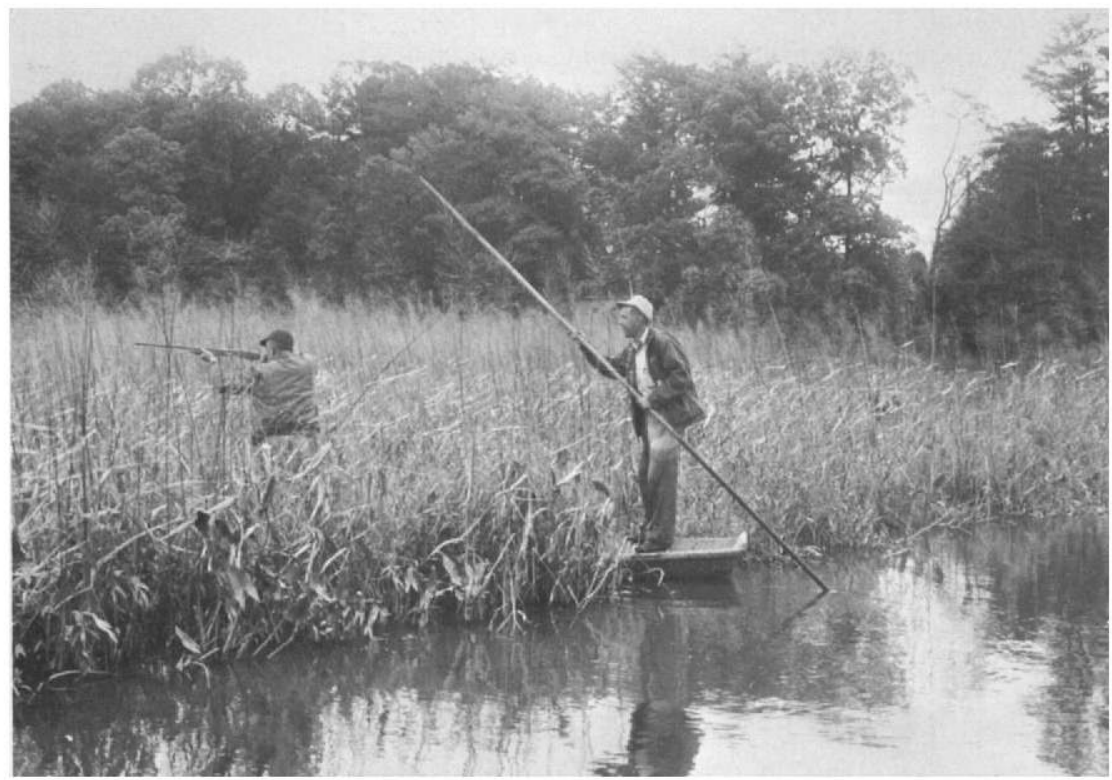

FIgURE 33.-Method of hunting railbirds in Patuxent River wildrice marshes in Maryland. Boat is poled through marshs at flood tide (September 1958). 


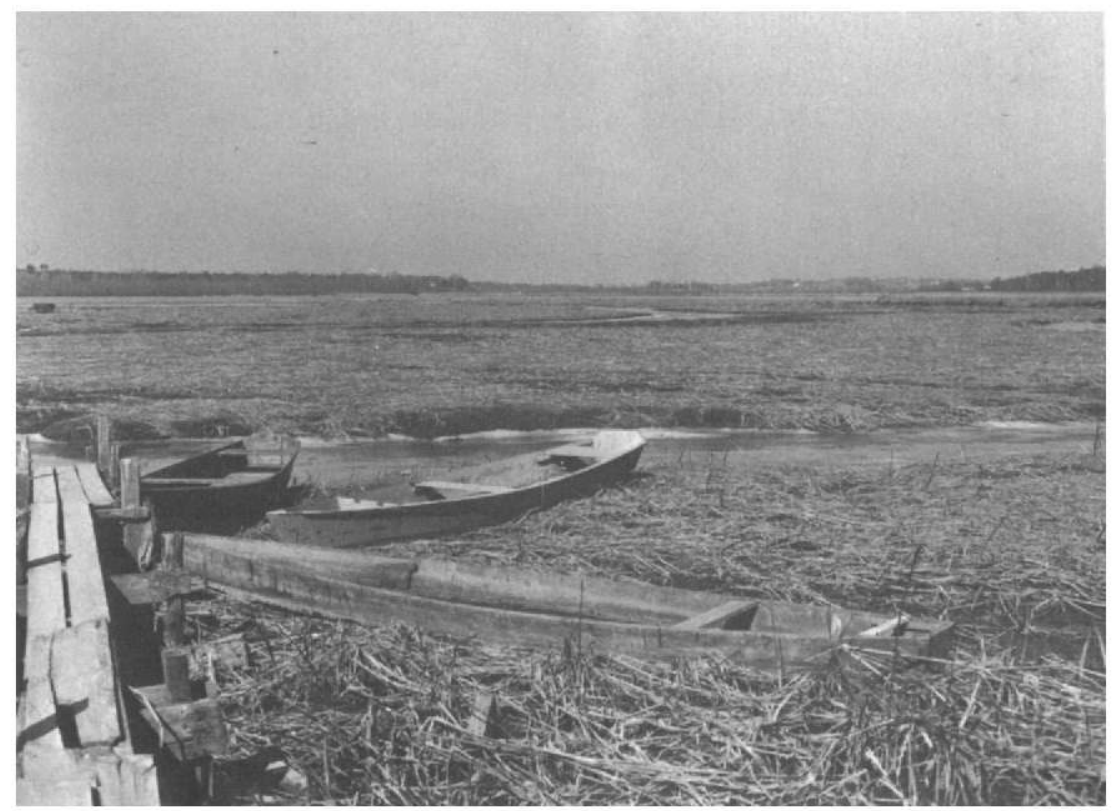

Froure 34.-After the hunting season : railbird boats tied up at dock in December. Low tide on old wildrice marsh on the Patuxent River in Maryland.

little book There Are No Dull Dark Days. He begins his essay with a poem about the Marsh Hen:

Give me a gun and some old Marsh

Where the pusher's voice calls mark right:

As the king rail springs from the ditch beyond

Then as suddenly drops out of sight.

"Dah he! Mark left!" What a thrill as the excited "pusher" calls the first bird on a beautiful September morn. This is the moment for which the gunnerman has waited many a month.

We are on the Patuxent. Everything has clicked; the wind is southeast and gentle, the day warm but not hot. . . high tide at $7: 30$ a.m. As far as the eye can see on both sides of the river, artistic stalks of wild "oats" stand. Over on the higher marshes, a solid mass of brilliant yellow blossoms, called butterweed by the natives, greets the eje.

Rails, being in good requisition for the table, have been extensively hunted, particularly on the marshes of the Delaware and Chesapeake bays. Most sought after of the rails is the little sora or Carolina rail. The Virginia and king rall often add variety to the bag, however.

It is next to impossible to make these birds take wing when they are able to run. Because of this, rail are hunted only when the tide is so high that the flooded marshes afford no shelter and make it impossible for them to run. While the pusher poles a small skiff over the flooded marsh, the hunter stands in the bow, gun in hand. Every now and then a bird will jump, sometimes almost from under the boat, flying away with apparent feebleness, just over the tops of the foliage. $A s$ it flies, its legs dangle awkwardly. This ruse, however, is merely to prepare it for the sudden drop which often leaves the surprised hunter drawing a bead 
on empty space. Oftimes the gunner doesn't even see the rail announced by Mark right, Mark left, or simply "Dah he goes."

On the Patuxent marshes in the 1940's, I would flush about 2 Virginia and 1 King to each 100 Sora.

\section{Eagle Lake area, Tex.}

The method of hunting King Rails in the Texas ricefields was described by Dev Klapp (1961, p. 14) :

On the Gulf Coast the rail is found in the great ricefields where it seeks its food. The close-knit rice stalks afford the bird ideal cover, and any attempt to hunt such terrain in an orthodox manner is next to useless. The hidden rail wonld merely sneak away as the hunter approached and never be seen.

So Texans waste no time slopping around through ankle-deep gumbo mud chasing a bird that refuses to flush. They patiently wait until rice harvest time, then, by the hundreds they take to the fields.

Beginning about October 1, reapers appear in the fields to gather the grain. The machines take positions at the outer perimeter of the flelds and, as the sun rises above the horizon, go into action. Snorting and rocking, they circle the flelds time and again, gradually working toward the center. Running side by side, usually in pairs, they cut a swath some 30 feet wide.

The hunters wait until all but a 30-10ot swath of rice is cut, then hurriedly take stands to each side of the uncut grain. In this narrow strip, they know, all the rall in the field are crowded. Reluotant to fly, the birds have crept through the standing grain, just abeed of the oncoming machines, until forced into this bit of cover.

As the reapers get about half-way through this swath the birds begin to panic. That's when the fun starts. A hunter suddenly shouts, "There's one!" as the flrst rail rises from cover, almast straight up. Before the bird has set its course it is brought down.

The combine (fig. 35) has replaced the reaper in most areas, but the method of hunting is still the same.

\section{Other areas}

Milton B. Trautman (personal communication) reported that between 1907 and 1918 King Rails were hunted in the marshes of Indian Lake, Logan County, Ohio, and that bags of half a dozen birds a day were not uncommon. M. G. Vaiden, an ornithologist from Rosedale, Miss., told me that while Bobwhite hunting in the delta, January 30 , 1945, he shot five King Rails and three Bobwhites; and on January 27, 1946, he shot four King Rails. The Rails were flushed from boggy spots in growths of ragweed (Ambrosia sp.).

In the days of the market gunner, rails were shot in much greater numbers than at present, and were sold in the markets of most of the large cities along the eastern seaboard. To the epicures, the King Rail of the fresh-water marsh was far superior to the Clapper Rail of the salt marsh. Charles S. Westcott ("Homo") writing in Forest and Stream magazine in the 1880's, said (Stone, 1937, p. 332):

Many of the latter, however, carefully plucked were palmed off for King Rails on those less expert in identifying them. 


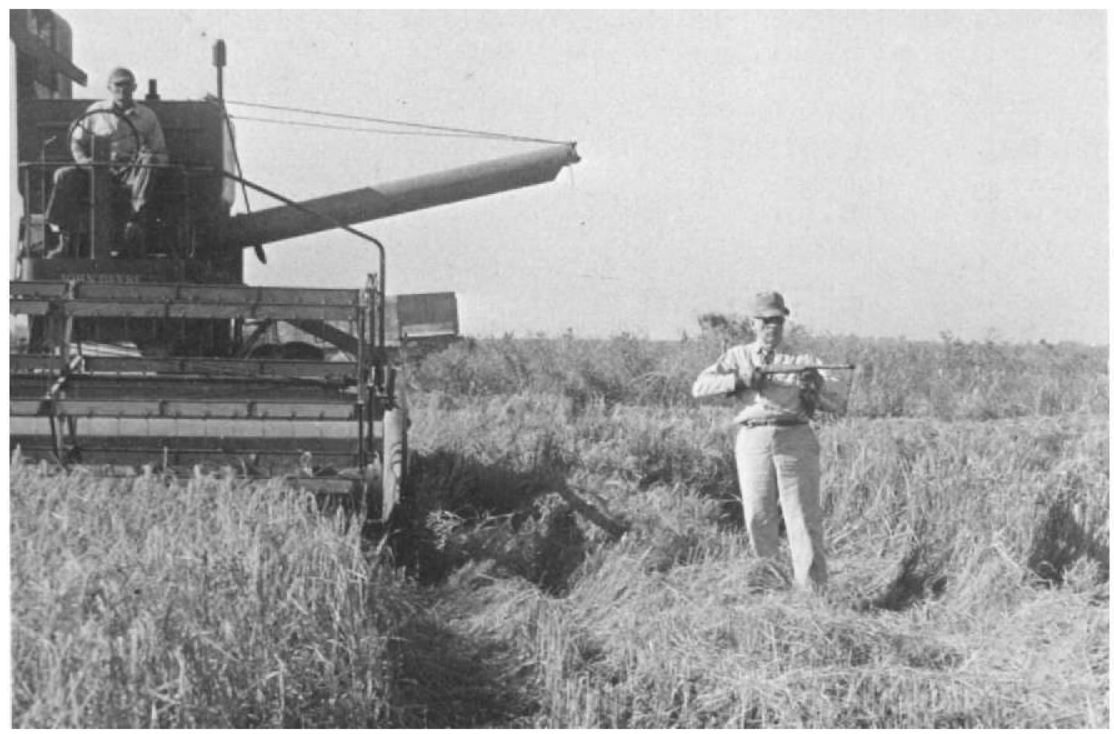

Frgure 35.-Method of hunting railbirds in southern ricefields. As rice is harvested the hunter walks beside the reel of the combine which flushes the birds. (Arkansas Grand Prairie, September 1953.) 


\section{Summary}

Audubon described the King Rail. Alexander Wilson and, for a while at least, Audubon considered it to be some form, perhaps an adult, of the Clapper Rail. Audubon and Bachman, staunch friends, spent a lot of time together in the Charleston area, where Bachman was able to show Audubon that the large rufescent rail was associated almost entirely with the fresh-water marshes and ricefields, while the "ash-coloured" rail was a denizen of the salt marshes. By so doing, Bachman apparently convinced Audubon that the two were distinct species.

The King Rail is essentially an inhabitant of fresh and brackish marshes, while the Clapper Rail is more an inhabitant of salt marshes. In some transition areas, however, particularly in the lower reaches of brackish river marshes, both species occur and sometimes interbreed. Viable eggs resulting from a mixed mating are known to occur, and some specimens taken in areas of interbreeding appear to be hybrids. Further study is necessary to understand more precisely the relationship between King and Clapper Rails.

Rallus elegans elegans is restricted mostly to the humid section of North America, east of the 100th Meridian. The Cuban form, $R$. e. ramsdeni, is restricted to Cuba and the Isle of Pines. A third form, R. e. tenuirostris (sometimes considered to be a race of Rallus longirostris), is restricted to the fresh-water marshes of the Valley of Mexico. In the United States the King Rail is found in greatest numbers in the South Atlantic and Gulf Coastal Plain provinces, especially in coastal iresh and brackish marshes and in ricefields.

While it has been shown that the King Rail is migratory, so few birds have been banded that little is known about the time, distance, and routes of migration. Apparently the major routes are along the Atlantic Coastal Plain and through the Mississippi Valley. Most birds probably arrive on the breeding grounds in the north during April and May and depart in August and September. Although most King Rails migrate to the South Atlantic and Gulf Coastal Plains in the fall, a few individuals may be found wintering almost anywhere within the geographic range of the species. Since there are numerous records of birds wintering in the middle and northern latitudes, it is not known whether birds seen in the spring are recent arrivals from the south or birds that have wintered in the area. Rails are very secretive in winter, becoming quite vociferous with the onset of the breeding season; thus spring arrival dates may be based on sighting or hearing of birds that have been present in the area for some time prior 
to the recorded date. During the summer King Rails may restrict their activities to a relatively small area for as long as 3 months, during which time the adults are nesting and molting, and the young, flightless for about 2 months after birth, are growing.

The 4,000,000-acre Louisiana coastal marsh is the largest block of breeding habitat in the range of the King Rail. The southern ricefields are a good example of an optimum breeding habitat. The breeding density of a King Rail population in a South Carolina river marsh was 25 males per 100 acres; in an inland Florida marsh the density was 30 males per 100 acres. King and Clapper Rails were found breeding in the same brackish marshes in Louisiana, Maryland, and Delaware.

King Rail sexes appear to be alike in plumage. The male averages larger than the female. Immature birds apparently can be externally distinguished from adults during the first autumn by the color of the soft parts. Most rails in juvenal and first-winter (immature) plumage have some white barring on the wing coverts. This is also true of some adults. The light-phase adult plumage described by Ridgway and Friedmann (1941) is probably typical of hybrids. The small sample of weights and measurements given in this report indicates that the King Rail averages slightly larger than the Clapper Rail.

Molt is not well understood. Apparently all individuals molt after the nesting season, but some also molt during it.

King Rails are known to return to the same section of the same marsh for several consecutive years to breed. Territories are established and maintained by aggressive behavior, primarily that of the male. The mating call, given by the male, presumably serves the same purpose as the song of a passerine bird on its territory, namely to attract a mate and to repel other birds of the same sex (but also, in the case of the King Rail, to maintain contact after pairing).

The display of the male during prenuptial courtship consists mostly in walking about with tail uplifted and white undertail coverts extended. After pairing, other forms of display and a repertoire of subdued calls are used to maintain the pair bond.

Copulation takes place near the nest site, before and during egg laying.

The nesting season of the King Rail is one of the longest among birds in the South. In Florida, there is evidence of nesting from January to July; and in Louisiana, from March to September. In the middle and northern latitudes the nesting season is usually about 3 to 4 months long.

Since the Clapper Rail in South Carolina is known to be doublebrooded, it is possible that the King Rail in the southern part of its range may also have more than one successful brood; however, this has not yet been established. 
Clutch size is large, averaging 10 or 11 eggs. There appears to be no geographic variation in clutch size.

Nesting success appears to be high in most areas. In one Arkansas sample, success was 75 percent; and in one Iowa sample it was 67 percent. Such success is probably due in some measure to the incubating birds' pugnacity toward would-be offenders. Survival of young until 2 weeks of age was about 50 percent in the Arkansas rice belt.

Downy young of the King Rail are black. A change from the downy plumage begins at about 1 month. Juvenal plumage is obtained in about 60 days, and wings are developed enough for short flights after the ninth week.

Usually chicks are more than 1 hour old before they can go over the nest and return. During the first month six different calls were recorded.

The King Rail occurs in a wider range of habitats and feeds on a greater variety of foods than most other North American rallids. Aquatic animals, particularly crustaceans, are its main food. Plant food items are taken more under emergency conditions. When the King Rail occurs in the same environment as the Clapper Rail, it may subsist mostly on a 1-item diet like that species.

In most areas King Rails feed mainly in shallow water where the depth is usually 2 or 3 inches. In Delaware Bay marshes, King Rails fed almost entirely on mud flats, exposed at low tide, and on the Arkansas Grand Prairie, in summer, they fed almost exclusively in ricefields.

In some areas King Rails were observed to have feeding territories to which they returned regularly at times other than the breeding season.

Most food items are ingested whole, but larger crustaceans often are dismembered before eating.

Mortality of King Rails apparently is due mainly to birds coming in contact with manmade objects, and to natural predation, especially the destruction of eggs by raccoons. Studies to determine the effects of pesticides on this rail have not been made; however, its favorite food, aquatic animal life, is highly susceptible to these chemical agents. In at least one intensive agricultural area, the Arkansas rice belt, where ecological conditions have not changed during the last 20 years, the King Rail has shown a marked decline.

The King Rail is one North American game bird that certainly is not overhunted. This is so primarily because the population is generally scattered and its habitat is usually difficulc for hunters to work through. The only time that $I$ found them concentrated and fairly easy to shoot was during the harvest in the Louisiana ricefields. A few are shot incidentally in the course of hunting Sora in the Middle Atlantic States, and Bobwhite in the deep South in damp piney woods. 


\section{Literature Cited}

\section{AMmRICAN ORNTTHOLOGISTR' UNTON.}

1957. Check-list of North American birds. 5th ed. Baltimore. $691 \mathrm{p}$.

Abthub, Stanley Cusbry.

1931. The birds of Louisiana. State of Louisiana, Department of Conservation, Bulletin 20. New Orleans. $598 \mathrm{p}$.

1937. Audubon, an intimate life of the American woodsman. Harmanson, New Orleans. $517 \mathrm{p}$.

AUDUBON, JOHN JAMES.

1834. Birds of America, vol. III. Robert Havell, Jr., London. 435 p.

1935. Ornithological blography, vol. 3. Adam and Charles Black. Edinburgh. $631 \mathrm{p}$.

Bagg, aAron Clark, and Samugl Atking Eliot, Jr.

1937. Birds of the Connecticut Valley in Massachusetts. The Hampshire Bookshop, Northampton, Mass. $813 \mathrm{p}$.

BAHLIE, JAMES L., Jr.

1940. King Rail breeding in Southern Ontario. Auk, vol. 57, No. 1, p. 109-110.

Bheromin, WiLLIAM J.

1942. Nesting birds and the vegetation substrate. Chicago Ornithological Soclety. $69 \mathrm{p}$.

Bent, Arthur Chembiand.

1928. Life histories of North American marsh birds. Smithsonian Institution, U.S. National Museum Bulletin 135.490 p.

BLAKDIN, W ARREN W.

1963. Renesting and multiple brooding studies of marked clapper ralls. In Procedings of the Seventeenth Annual Conference, Southeastern Association of Game and Fish Commissioners, Hot Springs, Ark., p. 60-68.

BLog, Phroy Thaymi.

1944. There are no dull dark days, H. G. Roebuck \& Son, Baltimore. 92 p.

BRIMLEY, C. S.

1887. Notes from Raleigh, N.C. Ornithologist and Oologist, vol. 12, No. 12, p. 201.

1917. Thirty-two years of bird migration at Raleigh, North Carolina. Auk, vol. 34, No. 3, p. 296-308.

BUL, JOHN.

1964. Birds of New York area, Harper \& Row, New York. $540 \mathrm{p}$.

Chamberratan, B. Rhems.

1960. Nesting season-Southern Atlantic Coast region. Audubon Field Notes, vol. 14, No. 5, p. 441-444.

Corming, How aBd.

1929. Journals of John James Audubon during his trip to New Orleans in 1820-1821. Club of Odd Volumes, Harvard Press, Boston. 234 p.

CoUlter, MaLCOLM W.

1957. Predation by snapping turtles upon aquatic birds in Maine marshes. Journal of Wildlife Management, vol. 21, No. 1, p. 17-21. 
Crutokshaki, Aman D.

1942. Birds around New York City. American Museum of Natural History, Handbook Series No. 13.489 p.

- (compiler).

1953-1968. (14 yearly counts 1952-1965). Christmas bird count (Cocoa, Florida).

Audubon Field Notes, vols. 7-20, Nos. 2. Page numbers variable.

DAWGON, WHTIAM LEON.

1903. Birds of Ohio. Wheaton Publishing Company, Columbus. $671 \mathrm{p}$.

DEANE, RUTHVEN.

1929. Some letters of Bachman to Audubon. Auk, vol, 46, No. 2, p. 177-185.

DUVAYL, ALLEN J.

1937. Birds observed on the coast of Virginia and North Carolina. Auk, vol. 54, No. 4, p. 461-463.

Errington, Paul L.

1932. Food habits of southern Wisconsin raptors; Part I, Owls. Condor, vol. 34, No. 4, p. 176-186.

and W. J. BRECKENRIDGE.

1938. Food habits of marsh hawks in the Glaciated Prairie Region of NorthCentral United States. American Midland Naturalist, vol. 17, No. 5, p. 831848.

ForkUBH, EDW ARD HowE.

1925. Birds of Massachusetts and other New England states, vol. 1. Massachusetts State Baard of Agriculture. $481 \mathrm{p}$.

FORD, EDW ARD $R$.

1956. Birds of the Chicago Region. Chicago Academy of Science, Special Publication No. $12.117 \mathrm{p}$.

GHLESPE, JoHN D.

1956. Bird names of the Mikasuki Seminoles. Florida Naturalist, vol. 29, No 4, p. 119-125.

Grimes, S. A.

1944. Birds of Duval County. Florida Naturalist, vol. 17, No. 4, p. 57-68.

Griscom, Ludow, and Maungml S. Crosby.

1925. Birds of the Brownsville region, southern Texas. Auk, vol. 42, No. 4, p. $512-532$.

Gross, ALFRED O., and JoskgLYN VAN TYNE.

1929. The purple gallinule (Ionornis martinicus) of Barro Colorado Island, Canal Zone. Auk, vol. 46, No. 4, p. 431-446.

GuLLion, Gorpon W.

1954. The reproductive cycle of American coots in California. Auk, vol. 71, No. 4, p. 366-412.

HaLLMAN, R. C.

1934. Notes from St. Johns County. Florida Naturalist, vol. 7, No. 2, p. 17-18.

Harmon, Borby G., Carl H. Thomas, and Leslis Glasgow.

1960. Waterfowl foods in Louislana ricefields. Transactions of the 25th North American Wildife and Natural Resources Conference, Wildlife Management Institute, Washington, D.C., p. 153-161.

HAYDEN, ADA.

1943. A botanical survey in the Iowa lake region of Clay and Palo Alto Counties. Iowa State College Journal of Science, vol. 17, No. 3, p. 277-416.

HOTCHKI8s, NHTr.

1950. Checklist of marsh and aquatic plants of the United Stater U.S. Fish and Wildlife Service, Wildlife Leaflet 210. $34 \mathrm{p}$.

Howkt, ARTHUR $\mathbf{H}$.

1932. Florida bird life. Florida Department of Game and Fresh Water Fish. Coward-McCann, New York. 579 p. 
HOXIE, W ALTER.

1887. Observations on nest building. Ornithologist and Oologist, vol. 12, No. 11, p. 181-182.

JohNston, RichaRd F.

1964. The breeding birds of Kansas. University of Kansas, Publication of the Museum of Natural History, vol. 12, No. 14, p. 575-655.

KALMBACH, E. R. 1937. Blackbirds of the Gulf Coast in relation to the rice crop. Unpub. MS in fles of U.S. Fish and Wildlife Service, Denver. $76 \mathrm{p}$.

Kentoge, Remington.

1929. The habits and economic importance of alligators. U.S. Department of Agriculture, Technical Bulletin 147. 36 p.

KIBKWOOD, F. C.

1895. A list of the birds of Maryland. Transactions of the Maryland Academy of Sciences, Baltimore, p. 241-381.

Krapp, Dev.

1961. Ricefleld rail. Texas Game and Fish, vol. 19, No. 10 (October), p. 14-15.

LATHAM, ROY.

1954. Nature notes from Orient (L.I.), Long Island Naturalist, vol. 3, p. 3-9.

Low, SETH H.

1935. Methods of trapping shore birds. Bird-Banding, vol. 6, No. 1, p. 16-22.

LOWRBY, Geonge H., Jr.

1955. Louisiana birds. Louisiana Wildlife and Fish Commission. Louisiana State

University Press, Baton Rouge. 556 p.

Martin, Alexander C., Herbert S. Zim, and Arnold L. Nelson.

1951. American wildlife and plants. MeGraw-Hill, New York. $500 \mathrm{p}$.

Mranlet, Brooke.

1953. Nesting of the king rall in the Arkansas ricefields. Auk, vol. 70, No. 3, p. 262-289.

1956. Food habits of the king rail in the Arkansas ricefields. Auk, vol. 73, No. 2, p. 252-258.

1963. KIng and clapper rails of Broadway Meadows. Delaware Oonservatlonist, vol. 9, No. 1, p. 3-7.

—_ and Davio KenNeTh WeTHerbze.

1962. Ecological notes on mixed populations of king ralls and clapper rails in Delaware Bay marshes. Auk, vol. 79, No. 3, p. 453-457.

Montagna, WmLiam, and William A. Wimsatt.

1942. Bird records from Virginia. Auk, vol. 59, No. 3, p. 434-436.

NAUMAN, E. D.

1927. Notes on the Rails. Wilson Bulletin, vol. 39, No. 4, p. 217-219.

Nmwan, R. J.

1957. Nesting season-Central Southem region, Audubon FYeld Notes, vol. 11, No. 5, p. 409-413.

Norkig, ROBERT A.

1963. Birds of the AEC Savannah River Plant Area. Contribution of the

Charleston Museum XIV, Charleston, S.C. 78 p.

NORTHWOOD, J. D'ARCY.

1956. Audubon'g firstg. Atlantic Naturalist, vol. 11, No. 5, p. 222-229.

OBERHOLGER, HARBY C.

1937. A revision of the clapper ralls (Rallus longirostris Boddaert). Proceed-

ings of the U.S. National Museum, vol. 84, No. 3018, p. 313-354.

1938. Bird life of Louisiana. State of Louisiana, Department of Conservation,

Bulletin 28. 834 p. 
ONEY, JoHN.

1954. Final report: clapper rail survey and investigation study. Georgia Game and Fish Commission, Atlanta. $50 \mathrm{p}$.

RAPP, F. W.

1931. Bird list of Vicksburgh, Michigan. Privately printed. 35 p.

Ridgway, Robert, and Herbert Friedmann.

1941. Birds of North and Middle America, part 9. Smithsonian Institution, U.S. National Museum Bulletin 50. 84 p.

ROBERTS, THOMAs S.

1936. The birds of Minnesota, vol. 1. University of Minnesota Press, Minneapolis. $821 \mathrm{p}$.

Sage, John Hall, and Louig Bennett Bishor.

1913. The birds of Connecticut. Connecticut Geological and Natural History Survey, Bulletin 20. 370 p.

Sprunt, Alexander, Jr., and E, BURn ham Chambertant.

1949. South Carolina bird life. University of South Carolina Press, Columbia. $585 \mathrm{p}$.

St. Amant, Lrue S.

1959. Louisiana wildlife inventory and management plan. Loulsiana Wildife and Fisheries Commission, New Orleans. 329 p.

Steirly, C. C.

1959. Breeding clapper rail in James River cord grass marshes. Raven, vol. 30, Nos. 5 and 6, p. $47-48$.

STEWART, JAMES R., Jr.

1965. Nesting season-Central Southern region. Audubon Field Notes, vol. 19, No. 5, p. 552-554.

STEW ART, ROBKRT E.

1952. Clapper rail studies. In Aldrioh, John W., et al., Investigations of woodcock, snipe, and rails in 1951 . U.S. Fish and Wildlife Service, Special Scientific Report-Wildlife 14, p. 56-58.

1954. Migratory movements of the northern clapper rail. Bird-Banding vol. 25, No. 1, p. 1-5.

1962. Waterfowl populations in the Upper Chesapeake Region. U.S. FIsh and Wildlife Service, Special Scientific Report-Wildlife 65. 208 p.

STONe, WiTMER

1908. The birds of New Jersey, in Annual Report of the New Jersey State Museum (for 1909). John L. Murphy Publishing Company, Trenton, 432 p.

1937. Bird studies at old Cape May, vol. 1. Delaware Valley Ornithological Club, Philadelphia. 520 p.

SW ALE8, B. $\mathbf{H}$.

1896. A "Full Set of Rails." Nidlologist, vol. 3, No. 12, p. 142.

TaN Ner, Ward D., Jr., and Geobez O. Hendroksor.

1956. Ecology of the king rail in Clay County, Iowa. Iowa Bird Life, vol. 26, No. 3, p. 54-56.

Tod, W. E. Clyde.

1940. Birds of western Pennsylvania. University of Pittsburgh Press, Pitteburgh, Pa. $710 \mathrm{p}$.

TOMKINA, IVAN $R$.

1958. The birdlife of the Savannah River Delta. Georgia Ornithological Society, Occasional Publication 4.68 p.

Trautman, Milton B.

1940. The birds of Buckeye Lake, Ohio. University of Michlgan, Museum of Zoology Miscellaneous Publication 44. $466 \mathrm{p}$. 
W ARKRR, DWATN W., and ROMERT W. DICKRRMaK.

1958. The status of Rallus elegans tenuirostris in Mexico. Condor, vol. 61, No. 1, p. $49-51$.

WATBON, GroBge E.

1962. Notes on the spotted rail. Wilson Bulletin, vol. 74 , No. 4, p. 349-356.

WaYNe, ARTH UR Trkezevant.

1910. Birds of South Carolina. Contribution from the Charleston Museum I, Oharleston, S.C. 254 p.

WeTherber, David Kenseth.

1959. Artifleial incubation of wild birds' eggs and developmental condition of neonates. $\mathrm{Ph}$. $\mathrm{D}$. Thesis, University of Connecticut (Library of Congress Card No. Mic 59-3872). $153 \mathrm{p}$.

WIDMaNN, OTto.

1907. A preliminary catalog of the birds of Missouri. Transactions Academy of St. Louis, St. Louis. 288 p.

WILBON, KanNeTh A.

1954. The role of mink and otter as muskrat predators in northeastern North Carolina. Journal of Wildlife Management, vol. 18, No. 2, p. 199-207.

WOOD, NORMAN A.

1951. Birds of Michigan. University of Mtchigan Museum of Zoology, Miscellaneous Publication 75. 559 p.

WOODFORD, JAMEs, and DONAID E. BURTON.

1961. Winter season and winter bird population study-Ontario-western New York region. Audubon Fleld Notes, vol. 15, No. 3, p. 326. 


\section{Appendix 1-Methods of Capturing for Banding}

Most of the King Rails captured for banding have been taken in traps or with long-handled dip or clap nets. A few downy young have been caught by hand. Some King Rails are inadvertently caught in the course of trapping ducks.

\section{TYPES OF GAPTURING DEVICES}

\section{Long-handled dip or clap net}

This device is very effective in capturing King Rails on nests. Traps equipped with drift fences and placed in breeding territories will also capture rails during the nesting season as the birds wander about their territories. However, in such situations, where only one or two birds are involved, long-handled nets are more efficient because of the time required to install traps. Most incubating King Rails can be approached closely enough to be caught on a first attempt. The long-handled net I use has a bamboo handle $71 / 2$ feet in length, a hoop 2 feet in diameter, and a net 3 feet in depth.

Nest traps are effective in catching incubating King Rails, but are time-consuming to construct and are probably no more effective than long-handled nets. Blandin (1936, p. 62-63) described a nest trap for the Clapper Rail, a species that flushes more readily from the nest than does the King Rail.

\section{All-purpose or cloverleaf trap}

As nearly as I can ascertain, this is the type of trap most often used for capturing King and Clapper Rails (figs. 36 and 37). Seth H. Low $(1935$, p. $16-20)$ originally designed this trap for catching shore birds for banding. He used long leads or drift fences placed at right angles to the trap and running up to the trap entrance. Robert E. Stewart $(1954$, p. 1) caught nearly 1,000 Clapper Rails with this type of trap at Chincoteague, $\mathrm{Va}$, and designed a very effective gathering cage that prevents rails from getting back into the trap (fig. 37). The effectiveness of Stewart's design is due to a ramp that begins at the opening at ground level and runs toward the top and rear of the cage. When a rail reaches the top of the ramp it drops down into a small chamber where it is well contained and easily retrieved.

The all-purpose trap used by Stewart and other Patuxent Wildlife Research Center biologists is about $61 / 2$ feet in length. Each of the two 


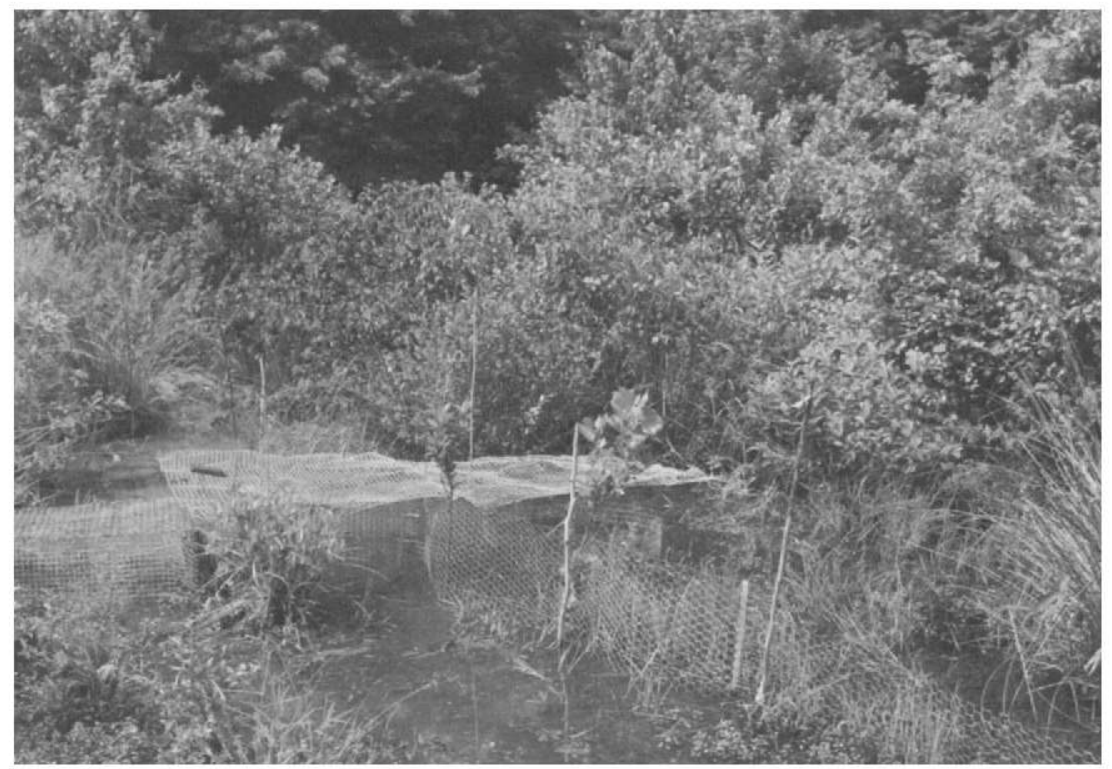

Frouke 36.-All-purpose or cloverleaf trap and drift fence in shrub swamp at Patuxent Whdlife Research Center, Laurel, Md.
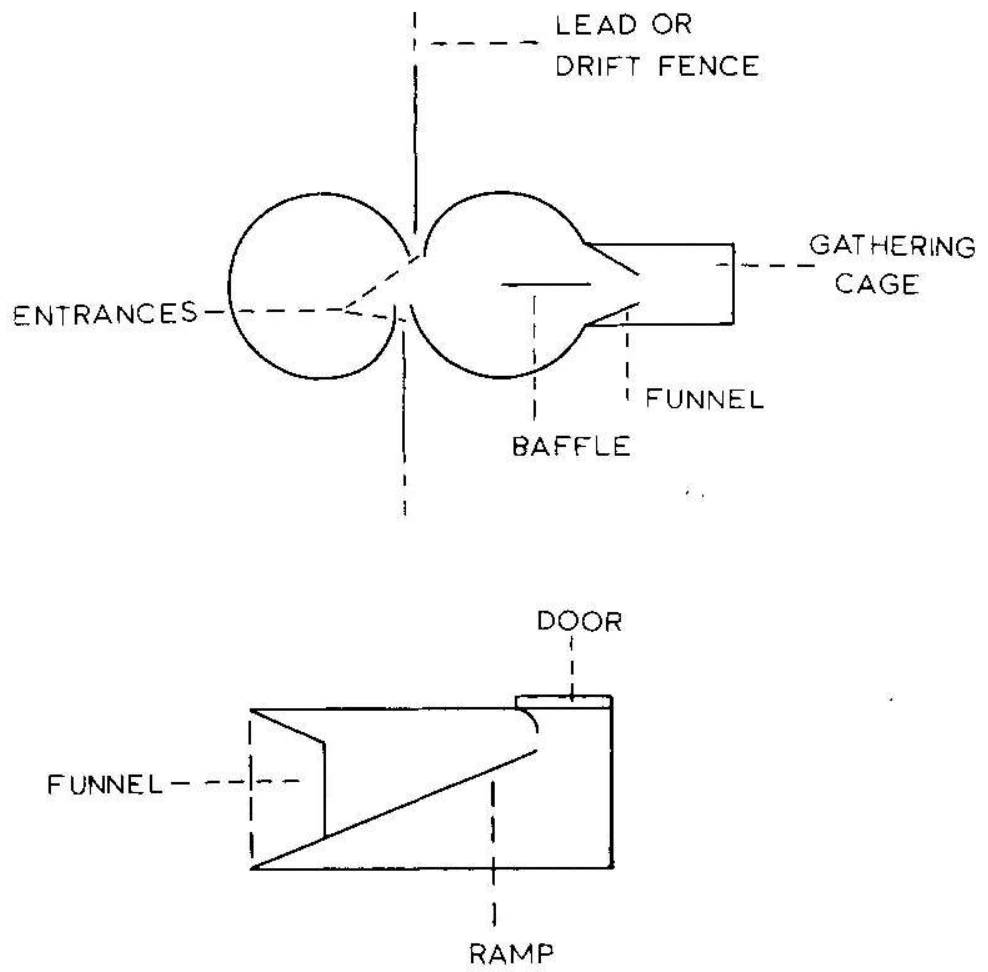

Figure 37,-All-purpose or cloverleaf trap. 
cells is about 3 feet by 3 feet; flattened out, each cell section is approximately 9 feet in length by $1 \frac{1}{2}$ feet in width. The top is 7 feet by 4 feet.

The trap is best made of hardware cloth or welded wire. A less expensive and also less durable trap can be made of 1-inch poultry mesh (chicken wire). A trap made of poultry mesh should have a hardware cloth gathering cage.

The lead wire or drift fence should be a minimum of 1 foot in height. Two feet is better. One-inch poultry mesh is an ideal size for the drift fence. Downy young of banding age can probably get through a 2 -inch mesh.

The length of the lead or drift fence depends upon the trapping situation. In marshy impoundments at the Patuxent Wildlife Research Center near Laurel, Md., I used some half-dozen different trapping designs at various times.

The trap is placed in that part of a marsh known to be inhabited by rails. Their presence is determined by hearing a bird call regularly from the same area during the course of several consecutive days, by locating a nest, or by hearing the cries of young that have been separated from their parents. The general area should be checked for tracks, droppings, and fragments of crayfish or other rail foods, and when tracks along a well-worn runway or path are found, the strategy then is to block it off with the drift fence.

Rails often feed along the edge of a marsh on a mud flat bordering open water. In such a situation, the drift fence should extend a foot or so out into open water and landward 10 or 15 feet (or more) to the trap. At low tide, in cordgrass marshes in Delaware, King and Clapper Rails feed along the exposed muddy bottoms of narrow creeks. In such a situation, a drift fence leading to a trap on either bank can be placed across the creek. Thus the rail's passage is cut off, and it tends to follow the fence toward the trap and often goes into it.

In a 10-acre shrub swamp-marsh mixture at the Patuxent Wildlife Research Center, the most select area for rails was in a 1-acre cattail patch. By placing four all-purpose traps about 30 feet apart in a row and connecting them with drift fences, I was able to block off an extensive area and succeeded in catching many rails (King, Virginia, and Sora). Numerous Common Snipe (Capella gallinago), Red-winged Blackbirds, Rusty Blackbirds (Euphagus carolinus), Swamp Spar: rows and Song Sparrows were also captured. A few Wood Ducks, Woodcocks, American Bitterns (Botaumus lentiginosus), and Green Herons (Butorides virescens) were taken as well. The trap placed at the pond end of the cattail patch caught more rails than did the three in the interior of the patch.

\section{TENDING TRAPS}

The number of times a day that traps should be tended depends somewhat upon the size of the population in the area of interest and 
the frequency of catch. In high population areas, such as some Clapper Rail marshes, traps should be checked four or five times a day. In areas of low population, two or three times a day is adequate, as too frequent disturbance will frighten rails from trapping sites.

In areas of high predation by raccoons, opossums (Didelphis virginiana), minks, and domestic rats, it is well to leave traps open at night. When operating on a 24-hour basis it is important to check the trap at dusk or shortly thereafter. Rails left in traps at night in areas of high predator populations will almost without exception be destroyed. This is especially so because paths made by the operator seem to become natural highways for mammals.

Between dusk and dawn I virtually never caught rails (King, Virginia, or Sora) in traps at the Patuxent Wildlife Research Center. Most species of North American Rallidae are not as active at night as during the day. Some rails are vociferous at night especially during the breeding season; however, at that time they call mainly from territories.

When I first started trapping rails, I expected to encounter trouble with muskrats getting into traps. They do get into traps occasionally, but burrow out quickly, and I have never had to remove a single animal.

\section{AGE FOR BANDING KING RAIL CHICKS}

Downy young can be banded at 2 weeks of age, a few individuals as early as 10 days. The band size is number 5 .

\section{NEED FOR BANDING DATA}

In view of the paucity of information on movements and population dynamics of rails, a large number of these birds should be banded. To accomplish this, it is necessary to know which methods are best for capturing rails, where to place traps, and in what geographic areas.

The all-purpose or cloverleaf trap with drift fences is the best known device for capturing rails for banding.

The best areas for trapping are usually determined by noting calls, reading "sign" (tracks, droppings, piece of discarded crayfish), and locating nests.

Localities in which I have found high populations are as follows: In Louisiana marshes near the intersection of the Intracoastal Waterway and the road to Pecan Island; just below the intersection of the Waterway along the road to Creole, and in a silted-in canal near Dulac; in marshes across the river (north) from Savannah, Ga.; and in marshes on the Savannah National Wildlife Refuge near Savannah. 


\section{Appendix 2-Local Names}

The King Rail is probably better known in life to marsh hunters and trappers than to most ornithologists, and to these hunters and trappers it has its own special name depending upon locality. I picked up many of these names while working in the marshes and ricefields of the South.

Great Red-breasted Rail Audubon (1835, vol 3, p. 27). Fresh-Water Marsh Hen Audubon (1835, vol. 3, p. 27).

Rale de Prairie Creole hunters of Louisiana according to Audubon (Arthur, 1931, p. 235).

English Rail Hunters on Arkansas Grand Prairie, Ark. (author).

Slash Guinea Hunters on Arkansas Grand Prairie, Ark. (author).

Sage Hen Southeastern Arkansas (Chicot County) rice farmers (author); also muskrat trapper, Rappahannock River, Va. (author).

Rice Guinea Northeast Arkansas rice belt around Weiner and Hickory Ridge (author).

Rice Chicken Northeast Arkansas rice belt around Weiner and Hickory Ridge (author).

King Sora Potomac River, Va. (Kirkwood, 1895, p. 278) ; Powhatan River, Va. (author).

King Ortlan Patuxent River, Md. (author).

King Water Rail Muskrat trapper, Choptank River, Md. (author).

Marsh Pullet Allen's Fresh, Wicomico River, Md. (author).

Mud HenNew England (Forbush, 1925, vol. 1, p. 352).

Injun Hen. Raleigh, N.C., area (Brimley, 1887 p. 201). 
Okankiskoki (ruddy raven)- Big Cypress Seminole Indians (Mikasukis), Florida (Gillespie, 1956, p. 123).

Oklani kahki (ruddy raven) - Cow Creek Seminole Indians (Muskogee), Florida (Gillespie, 1956, p. 123).

Marsh Hen

Stage Driver.-.-_-_._._.-. Isake Erie marshes, Ohio (author). 